\title{
The challenges and needs of older people as HIV and AIDS caregivers in South Africa
}

Citation for published version (APA):

Boon, H. (2010). The challenges and needs of older people as HIV and AIDS caregivers in South Africa. [Doctoral Thesis, Maastricht University]. F\&N Boekservice. https://doi.org/10.26481/dis.20100506hb

Document status and date:

Published: 01/01/2010

DOI:

10.26481/dis.20100506hb

Document Version:

Publisher's PDF, also known as Version of record

\section{Please check the document version of this publication:}

- A submitted manuscript is the version of the article upon submission and before peer-review. There can be important differences between the submitted version and the official published version of record.

People interested in the research are advised to contact the author for the final version of the publication, or visit the DOI to the publisher's website.

- The final author version and the galley proof are versions of the publication after peer review.

- The final published version features the final layout of the paper including the volume, issue and page numbers.

Link to publication

\footnotetext{
General rights rights.

- You may freely distribute the URL identifying the publication in the public portal. please follow below link for the End User Agreement:

www.umlib.nl/taverne-license

Take down policy

If you believe that this document breaches copyright please contact us at:

repository@maastrichtuniversity.nl

providing details and we will investigate your claim.
}

Copyright and moral rights for the publications made accessible in the public portal are retained by the authors and/or other copyright owners and it is a condition of accessing publications that users recognise and abide by the legal requirements associated with these

- Users may download and print one copy of any publication from the public portal for the purpose of private study or research.

- You may not further distribute the material or use it for any profit-making activity or commercial gain

If the publication is distributed under the terms of Article $25 \mathrm{fa}$ of the Dutch Copyright Act, indicated by the "Taverne" license above, 
The challenges and needs of older people as HIV and AIDS caregivers in

\author{
South Africa
}





\section{THE CHALLENGES AND NEEDS OF OLDER PEOPLE AS HIV AND AIDS CAREGIVERS IN SOUTH AFRICA}

\section{PROEFSCHRIFT}

ter verkrijging van de graad van doctor aan de Universiteit Maastricht, op gezag van de Rector Magnificus, prof. mr. G.P.M.F. Mols volgens het besluit van het College van Decanen,

in het openbaar te verdedigen

op donderdag 6 mei 2010 om 12.00 uur

door

Hermien Boon 


\section{Promotores:}

Prof. dr. H.W. van den Borne

Prof. dr. S.P. Reddy (Medical Research Council, South Africa)

\section{Copromotor:}

Dr. R.A.C. Ruiter

Beoordelingscommissie:

Prof. dr. G.J. Kok (voorzitter)

Dr. A. Krumeich

Dr. S. Sifunda (Medical Research Council, South Africa)

Prof. dr. N.K. de Vries

\section{Colophon}

Cover design \& lay out by: Dymph Dressen-Moons

Printed by: F\&N Boekservice, Amsterdam

Copyright $\odot$ Hermien Boon, Maastricht 2010

ISBN: 9789078675815

The research reported in this thesis was funded by Horizons

Program, Population Council under sub-agreement numbers AI06.10A, A104.17A and HRN-A-00-97-00012-00. 


\section{Contents}

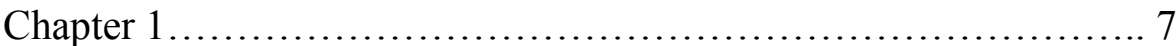

Introduction

Chapter 2

Challenges for older caregivers in a time of HIV and AIDS in South Africa: a focus group discussion

Chapter 3

Correlates of grief among older adults caring for children and grandchildren as a consequence of HIV and AIDS in South Africa

Chapter 4 .

Explaining perceived ability among older people to provide care as a result of HIV and AIDS in South Africa

Chapter 5

The impact of a community-based pilot health education intervention for older people as caregivers of orphaned and sick children as a result of HIV and AIDS in South Africa

Chapter 6

General Discussion

References.................................................133

Summary.................................................... 145

Samenvatting............................................. 151

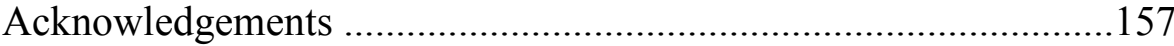

Curriculum Vitae .........................................................................159 

Chapter 1

Introduction 


\section{Introduction}

Over the past few decades, the HIV and AIDS epidemic has become one of the most important social and public health challenges in South Africa. With 5.4 million people infected and a nationwide prevalence of 29.1 per cent for antenatal clinic attendees in 2006 (Department of Health, 2007), the high infection rates place a heavy burden of care on the health care system and on society in general. Health services are often unable to accommodate an increasing number of patients, and families are obliged to take care of their sick and terminally ill relatives at home (Ndaba-Mbata \& Seloilwe, 2000). Besides often young people who are infected with HIV return home at a terminal stage of there illness to be nursed and eventually die in the hands of mostly their older family members (Clark, Collinson, Kahn, Drullinger, \& Tollman, 2007; Collinson, Tollman, \& Kahn, 2007; Knodel, 2005; Knodel \& VanLandingham, 2002; Marais, 2005; Nyambedha, Wandibba, \& Aagaard-Hansen, 2003a; Schatz, 2007; Ssengonzi, 2007, 2009). Among people between the ages of 15 and 49 , who are most sexually and economically active, the infection rate is $18.3 \%$ (Department of Health, 2007). As young parents get sick and die, orphans are left behind who then have to be taken care of by the community and the extended family. Increasingly large numbers of older people are thus assuming responsibilities for bringing up orphans and vulnerable children, bearing both the costs and consequences of care (Foster, Makufa, Drew, Kambeu, \& Saurombe, 1996; HelpAge International, 2004; Juma, Okeyo, \& Kidenda, 2004; Ssengonzi, 2007; World Health Organization, 2002). The emphasis on community and home-based care as a strategy for meeting the care and support needs of those infected and affected by HIV and AIDS has impact on the psychosocial and physical well-being of the family caregivers and on the care they provide. This dissertation describes the impact of HIV and AIDS on the lives of older people who provide care for sick adult children and grandchildren who are left behind. 


\section{Care for adult sick children and orphaned grandchildren in}

\section{South Africa}

The care for sick adult children and orphaned grandchildren is mostly left in the hands of elderly parents (Ntozi, 1997a; Ntozi \& Nakayiwa, 1999; Williams \& Tumwekwase, 2001), and mainly elderly women (Dayton \& Ainsworth, 2002; Freeman \& Nkomo, 2006; Kipp, Tindyebwa, Karamagi, \& Rubaale, 2007a; Madhavan, 2004; Opiyo, Yamano, \& Jayne; 2008; Schatz \& Ogunmefun, 2007; Ssengonzi, 2007, 2009; Thomas, 2006; World Health Organization, 2002). A recent study in South Africa showed that $68 \%$ of caregivers were women or girls, with $23 \%$ of them being over the age of 60 years (Steinberg, Johnson, Schierhout, \& Ndegwa, 2002). Older people have to assume both productive and child-raising duties (Chazan, 2008; Marais, 2005) and with little or no support endure the emotional, physical, financial and social costs that arise from their role as caregivers (Freeman \& Nkomo, 2006; HelpAge International, 2003; Ntozi \& Nakayiwa, 1999; Nyambedha, Wandibba, \& AagaardHansen, 2003a; Reddy, 2005; Schatz, 2007; Ssengonzi, 2007). Although the older people express various difficulties in fulfilling the wide range of care responsibilities, they do so willingly (Freeman \& Nkomo, 2006; Madhavan, 2004; Thomas, 2006) and claim considerations of love and responsibility as main drives for providing care (Nyambedha, Wandibba, \& Aagaard-Hansen, 2003a; Orner, 2006), enabling the wellbeing of their children and grandchildren (Chazan, 2008; Schatz, 2007).

The situation of grandparents caring for their sick children and grandchildren however is not new in South Africa. During the history of Apartheid and labour migration African families in the past were systematically divided by recruiting younger men and women to the centres of employment (Chazan, 2008; Hosegood \& Timaeus, 2006; Madhavan, 2004; Marais, 2005). Families were in reciprocal exchange 
as older people facilitated the economic migration of younger adults by caring for their grandchildren and safeguarding the family land and assets (Hosegood \& Timaeus, 2006). In return young grandchildren would assist with house and farm work and absent adult children would provide the family with income (Madhavan, 2004). What is new to this particular situation is that HIV and AIDS have undermined the traditional reciprocal care arrangements as migrant parents fall ill and die and therefore can no longer provide remittances to the grandparents caring for their children (Chazan, 2008; Madhavan, 2004; Marais, 2005). Besides the scale of the loss from HIV and AIDS over a prolonged period of time has a major impact on the lives of many older people (Knodel, Watkins, \& VanLandingham, 2003; Seeley, Wolff, Kabunga, Tumwekwase, \& Grosskurth, 2009) as they now take sole responsibility for the care and upbringing of sick adult children and orphaned grandchildren with limited resources (Foster et al., 1996; HelpAge International, 2003; Madhavan, 2004; Madhavan \& Schatz, 2007; Ssengonzi, 2007).

The HIV and AIDS epidemic has seriously worsened the welfare of older people and caused a certain role reversal, as they are of an age when many would have become recipients of care and would have expected the rest and respect that comes with old age (Cattell, 1990; Seeley et al., 2009). Circumstances have however forced them into roles that younger relatives would have performed had they lived (Ntozi \& Nakayiwa, 1999; Seeley et al., 2009) and forced a reorganization of existing family structures (Ankrah, 1993; Appleton, 2000; Foster, Makufa, Drew, Mashumba, \& Kambeu, 1997; Lindsey, Hirschfeld, Tlou, \& Ncube, 2003; Madhavan, 2004). In addition, in times of crises when children are dying and becoming orphaned by HIV and AIDS, providing care becomes a social obligation and reciprocity of kinship resources become less important (Madhavan, 2004). 


\section{Care challenges}

The challenges that older people face as a result of becoming caregivers and losing their adult children are manifold as HIV and AIDS puts constraints on their financial, social, emotional and physical situation. The economic difficulties are manifested threefold: (1) older people suffer as they lose income and support provided by children who become sick and die (Appleton, 2000; HelpAge International, 2004; Lindsey et al., 2003; Moore, 2008; Seeley et al., 2009; Williams \& Tumwekwase, 2001); (2) loss of income due to the inability to work because of old age (Nyambedha, Wandibba, \& Aagaard-Hansen, 2003a) or the inability to leave the sick child or grandchild alone at home; and (3) loss of savings and personal belongings due to high expenses for schooling or medical treatment for their dependents (Freeman \& Nkomo, 2006; Nyambedha, Wandibba, \& Aagaard-Hansen, 2003a; Ssengonzi, 2007). The national means-tested non-contributory pension programme in South Africa appears to mitigate the impact of the lack of income and boosts the coping mechanisms of caregivers (Hosegood \& Timaeus, 2006; Ssengonzi, 2007). However, the old age pensions grant may now act as a substitute to support the needs of sick children and orphaned grandchildren instead of supporting the needs of older people. Income that was once intended to sustain older individuals in their old age is now maintaining extended households (Barrientos et al., 2003; Ferreira, 2004; Freeman \& Nkomo, 2006; May, 2003; Ogunmefun \& Schatz, 2006; Schatz \& Ogunmefun, 2007). Even though 66\% of all older people over the age of 60 years and older did receive a pension grant in 2008 (Department of Social Development, 2008; Statistics South Africa, 2008), older people often lack the correct documents and knowledge to apply for additional grants for their dependent children or grandchildren (Schatz \& Ogunmefun, 2007).

Besides the financial difficulties, older caregivers endure also challenges on the social level as loneliness and social isolation 
increase when caring duties require substantial amounts of time away from livelihood and social activities, such as going to church or funerals (Lindsey et al., 2003; Mwinituo \& Mill, 2006; Orner, 2006; Thomas, 2006). Closely related to the social burden of care, older people have to face the issue of stigmatization of people living with HIV or AIDS and their caregivers (Appleton, 2000; Mwinituo \& Mill, 2006). Social stigma reaches far beyond HIV and AIDS and is also experienced by people with chronic and terminal illnesses and their caregivers (Lindsey et al., 2003). The stigma associated with HIV and AIDS results in caregivers providing care to their relatives in absolute secrecy, besides caregivers are cautious in disclosing the diagnosis of their patients (Lindsey et al., 2003; Mwinituo \& Mill, 2006). As a result of not sharing information on the child's diagnosis with extended family members, limited or no support was received from them (Moore, 2008; Mwinituo \& Mill, 2006) and access to services was prevented (Lindsey et al., 2003). This subsequently leads to more fatigue and burden of care (Thomas, 2006).

Next to financial and social consequences, caring for sick adult children and orphaned grandchildren place considerable emotional demands on caregivers, negatively impacting on their psychosocial status (Orner, 2006). Older caregivers express feelings of hopelessness, worry, anxiety and depression not only about the state of things now, but also about the future (Ssengonzi, 2007). Many older people expect that they will be rewarded one day for the care they provided to their children and grandchildren. It is hoped that children and grandchildren will return assistance when the older people themselves are in need (Schatz, 2007). However with the high prevalence of HIV and AIDS, this expectation is often not fulfilled, which could lead to possible disappointment and additional psychological stress. Furthermore, emotional stress increases as older caregivers are unable to provide adequately for their dependents (Moore, 2008) and see their child die in front of their eyes, no matter how much effort they put into it (Thomas, 2006), with feelings of hurt, 
pain and grief as a result. Grief can be defined as the affectionate reaction of a stressful life event (Stroebe, 1992). In response to the death of a child, parental grief is believed to last longer and be more complicated than loss of another family member, even a spouse (Middelton et al., 1998; Moore, 2008). Bereaved people are more likely to have a wide range of physical and psychological health problems (Stroebe, Schut, \& Stroebe, 2007). Besides, proper bereavement, an adjustment period and proper counselling after the loss of the child is often not possible, as older people have to be emotionally and physically strong to support their grandchildren that have been left behind as a result of a parent's death. With the care for grandchildren new responsibilities and challenges come along for example reinforcing discipline and assisting with their homework (Kipp et al., 2007a). This often results in disrespect from grandchildren to the elders causing more emotional stress and personal sacrifice; often resulting in psychological disturbance and losing hope in life in general (Nyambedha, Wandibba, \& AagaardHansen, 2003a). Older people feel overwhelmed and exhausted by their care-giving responsibilities and are in urgent need for time to relax themselves (Lindsey et al., 2003).

Finally, as the health situation of their children deteriorates (Ainsworth \& Dayton, 2003), older people have to continue to assume physical care activities for their sick dependents involving preparation of food and medicines, bathing adult children, cleaning sores, carrying immobile patients to the toilet or to sit in the sun or shade, washing soiled clothes and sheets (Thomas, 2006). Furthermore, they provide care for family members with incontinence, vomiting, diarrhoea, confusion, skin lesions, and pain (Lindsey et al., 2003). As a result of less financial means, older people may have to cut on costs such as food and medical expenses on themselves and in combination with the heavy physical care they provide may be confronted with even a further decrease in their physical well-being (Dayton \& Ainsworth, 2004). 


\section{Needs of older caregivers and need for interventions}

A lack of skills and knowledge to provide basic care for sick dependents is perceived by older people (Kipp et al., 2007a; NdabaMbata, \& Seloilwe, 2000; Olenja, 1999; Ssengonzi, 2007). Furthermore, there is a lack of adequate and accurate information, particular in relation to HIV and AIDS prevention and care (Seeley et al., 2009; Ssengonzi, 2007). A further absence of basic material and professional support for the caregivers and the inability to provide proper care overburdens them and leaves them feeling despondent and powerless (Ndaba-Mbata \& Seloilwe, 2000; Ssengonzi, 2007; Thomas, 2006). There is also a need for direct financial assistance as family savings and pension grants are insufficient to support households with numerous members, many of whom still of schoolgoing age (Kipp et al., 2007a; Schatz \& Ogunmefun, 2007; Ssengonzi, 2007). In addition, there is a need for social support as older people lose support from children who used to provide the elders with an income (Seeley et al., 2009). Furthermore social support is often limited by the level of poverty in the community (Thomas, 2006) and by the changing traditional values of solidarity and respect for the older generation (Nyambeddha, Wandibba, \& Aagaard-Hansen, 2003).

Although researchers have examined many aspects of the HIV and AIDS epidemic, very little detailed analyses have been directed at understanding the effects of the epidemic on the elderly. The impact of HIV and AIDS on the elderly and their ability to cope with the burden of care imposed upon them has not been adequately studied and certainly has not been the subject of systematic intervention studies designed to mitigate the effect of HIV and AIDS on the lives of elderly caregivers as well as those for whom they care.

Even though the existing research provides a large framework of information about the impact of HIV and AIDS on older people as 
caregivers of their sick adult children and their grandchildren, there is a paucity of community programmes and public support for older people, and a lack of government policies to address the needs of older caregivers. To optimally design these interventions, studies are needed to identify high-priority needs of older caregivers and develop strategies to meet them. It is for this reason that it was decided to investigate the issue of older people caring for HIV and AIDS orphans and people living with HIV and AIDS with respect to developing and testing a targeted intervention programme. The project involved the systematic study of various environmental and psychosocial determinants of care-giving among older people and made a modest beginning for the development of a targeted intervention programme.

\section{Outline of the thesis}

This thesis aims to explore the problems faced by older caregivers as a result of HIV and AIDS in South Africa and what determines grief associated with loss of a child due to AIDS, the predictors of the ability to provide care, and to test a pilot intervention programme. Each of the chapters describes one of the studies that were conducted. As the chapters of this thesis are presented as journal articles, some overlap of information might occur.

Chapter two emanates from a qualitative study among 89 older caregivers from Motherwell and Uitenhage in the Eastern Cape province of South Africa. This study explored the expanding changing role of older people as caregivers and their responsibilities and challenges in caring for sick adult children and orphaned grandchildren. The study investigated the scope of care provided by older persons for HIV and AIDS affected dependants and the challenges and needs. The results showed that older people fulfil a wide range of responsibilities with a minimum of resources, assistance and support and suffer major economic, psychological and social consequences as a result. 
Chapter three describes the determinants associated with grief and was conducted among 820 older caregivers from Motherwell $(\mathrm{N}=$ $488)$ and Uitenhage $(\mathrm{N}=332)$. The study focused on the experience of grief among older adults caring for children and grandchildren as a result of HIV and AIDS and identified predictors of grief as variables for change to develop coping strategies and support. The results provided useful information for further research and development of targeted intervention programmes and supportive structures to assist older people in their tasks as caregivers and to mitigate the effects of HIV and AIDS on their lives and those for whom they care.

Chapter four was based on a cross-sectional study on the determinants of the ability to provide care among 409 isiXhosa speaking caregivers of 60 years and older. To inform future interventions that aim to provide caregivers with the necessary skills and support, chapter four focused on understanding the perceived abilities of older caregivers in caring for sick and orphaned children. Based on previous research, dependent variables were determined and consisted of perceived ability to provide basic nursing care, perceived ability to communicate with children in different generations, perceived ability to provide income and perceived ability to relax. This chapter identifies the psychological and environmental correlates of the perceived ability to provide different aspects of care among older caregivers.

Chapter five presents the effectiveness of a pilot intervention programme that was implemented among 202 older caregivers in Motherwell and aimed to address the determinants of perceived ability among older people to provide care for sick children and vulnerable grandchildren, by using suitable strategies such as for example verbal persuasion and practical skills development. The objectives of the intervention programme were to (1) build capacity among older caregivers to provide quality care to sick and orphaned children and grandchildren, (2) enhance the ability of older caregivers to cope with their psychosocial needs, (3) facilitate intergenerational 
communication between older caregivers and their dependents, including on HIV and AIDS prevention issues, and (4) facilitate the dissemination of information to older people on existing community and social support services. It was hypothesized that participation in the four sessions of the developed health education intervention would result in more knowledge on topics associated with HIV and AIDS and a higher perceived ability to take care of sick adult children and grandchildren. The results were measured in a one-group longitudinal design. In addition results were compared between participants who completed all workshops versus those who eventually only attended a few or no workshops.

Chapter six provides a general discussion and interpretation of the results, followed by the methodological aspects of the different studies and implications for practice. It concludes with recommendations to inform the further development of communitybased interventions focusing on the needs of older caregivers in the South African context. 


\section{Chapter 2}

Challenges for older caregivers in a time for HIV and AIDS in South Africa:

A focus group study

\section{Based on:}

Boon, H., James, S., Ruiter, R.A.C., van den Borne, B., Williams, E., \& Reddy, P. Challenges for older caregivers in a time for HIV and AIDS in South Africa: A focus group study. To be re-submitted to Ageing \& Society. 


\section{Introduction}

South Africa has one of the fastest growing Human Immunodeficiency Virus (HIV) and Acquired Immune Deficiency Syndrome (AIDS) epidemics in the world with 5.4 million people infected and a nationwide HIV prevalence of 29.1 per cent for antenatal clinic attendees in 2006 (Department of Health, 2007). This high level of HIV and AIDS infection places a heavy burden of care on the society. Research in South Africa, Uganda, Kenya and Thailand has shown that many of those who are infected with HIV return home at a terminal stage of their illness and expect elderly parents to care for them until they die (Schatz, 2007; Collinson, Tollman, \& Kahn, 2007; Ssengonzi, 2007; Nyambedha, Wandibba, \& Aagaard-Hansen, 2003a; Knodel \& VanLandingham, 2002). The children leave the elderly with no choice but to take on the role of caregiver and provide daily support and care, physically, emotionally, as well as economically (Schatz, 2007; Ntozi \& Nakayiwa, 1999; Nyambedha, Wandibba, \& Aagaard-Hansen, 2003b; HelpAge International, 2003; Reddy, 2005; Freeman \& Nkomo, 2006). Moreover, when young parents in their economic viable years of life get sick and die, they leave behind orphans who then have to be taken care of by the community and extended family. Increasingly large numbers of older people are thus assuming full responsibility for bringing up orphans and vulnerable children and have to bear both the costs and the consequences of care (Foster, Makufa, Drew, Kambeu, \& Saurombe, 1996; World Health Organization, 2002; UNICEF, 2003; HelpAge International, 2004; Juma, Okeyo, \& Kidenda, 2004; Ssengonzi, 2007).

\section{Challenges elderly face}

As a result of caring for sick adult children and orphaned grandchildren, the elderly experience financial, emotional and physical difficulties (Schatz 2007; Posel, Kahn, \& Walker, 2007; 
Schatz \& Ogunmefun, 2007; Ssengonzi, 2007), as well as social exclusion due to the association with HIV and AIDS in their household (Schatz, 2007; Mwinituo \& Mill, 2006). The economic difficulties manifested are threefold: loss of income and support previously provided by children who became sick and passed away (Ssengonzi, 2007; Schatz \& Ogunmefun, 2007), loss of income due to the inability to work because of sick or young children at home, and loss of savings or personal belongings due to high expenses for schooling or medical treatment for their dependents (HelpAge International, 2003; Ssengonzi, 2007). Furthermore, elderly express negative emotional and psychological effects of the care-giving activities such as worry, anxiety, depression and a feelings of hopelessness, not only about how things are at the moment but also about the future (Ssengonzi, 2007). Many elderly expect that they will be rewarded one day for the care they provided to their children and grandchildren. It is hoped that children and grandchildren will return assistance when the elderly themselves are in need (Schatz, 2007). With the high prevalence of HIV and AIDS, however, this expectation is often not fulfilled, which could lead to disappointment and additional psychological stress. Also, as a result of less financial means due to providing care, elderly may have to cut on costs such as food and medical expenses on themselves which may result in a decrease in physical well-being (Dayton \& Ainsworth, 2004).

The concept of grandparents caring for their children and/or grandchildren is not new in the African context. Older people have always been involved in caring for grandchildren to a certain extent, due to their children migrating to seek employment, and to provide the household with income (Madhavan, 2004; Ssengonzi, 2007). However, as a result of the HIV and AIDS epidemic, the caring problem has expanded to an exceptionally high degree and many elderly caregivers nowadays take sole responsibility for the care and upbringing of sick adult children and orphaned grandchildren 
(Madhavan, 2004; Foster et al., 1996; HelpAge International, 2003; Ssengonzi, 2007; Madhavan \& Schatz, 2007).

Several aspects of the impact of the HIV and AIDS epidemic on the community have been covered in existing research, varying from economic consequences for the family (Schatz \& Ogunmefun, 2007; Duflo, 2003), community care for orphans and vulnerable children (Freeman \& Nkomo, 2006; Foster, 1998), children returning home to die (Clark, Collinson, Kahn, Drullinger, \& Tollman, 2007; Knodel \& VanLandingham, 2002), and general issues such as changing household structures (Wittenberg \& Collinson, 2007; Madhavan \& Schatz, 2007). Some research has focused specifically on the elderly, examining the responsibilities they face as a result of their children being affected by HIV and AIDS, as well as the impact it has on their own well being and health (Ssengonzi, 2007; Schatz, 2007; World Health Organization, 2002; Nyambedha, Wandibba, \& Aagaard-Hansen, 2003a; Ntozi \& Nakayiwa, 1999; HelpAge International, 2003). However, these studies have not been the subject of experimental and longitudinal designs to test interventions that aim to ease the effect of HIV and AIDS on the lives of elderly caregivers and those for whom they care. This study aims to obtain information that could be used in the development of an intervention to address the specific needs of the elderly as providers of care.

\section{Method}

\section{Participants and Setting}

This is a qualitative study using in-depth focus group techniques. The study participants consisted of isiXhosa speaking elderly people, 60 years and older who lived in the informal settlements of Motherwell in Port Elizabeth and KwaNobuhle in Uitenhage in the Eastern Cape province in South Africa. The Eastern Cape is home to the former homelands of Transkei and Ciskei and has

a rich cultural heritage with a predominantly isiXhosa speaking 
population. As a result of Apartheid, the Eastern Cape has been neglected economically and is one of South Africa's poorest provinces (Statistics South Africa, 2000) with many informal settlements. These "townships" experience high rates of unemployment and poor living conditions (Eastern Cape Provincial Government, 2008), as well as a high HIV prevalence of 28.6 per cent among antenatal clinic attendees in 2006 (Department of Health, 2007). The lack of resources in this area places a large amount of responsibility on the shoulders of the community and puts the elderly in a difficult situation as care-givers of the sick and vulnerable.

\section{Procedure}

Twelve focus group discussions where conducted with 89 elderly people. The elderly were selected by community health workers, who knew them personally and who worked with them on a daily basis. They were selected because they were known to provide care to their sick unemployed children and/or their orphaned grandchildren, mostly as a result of HIV, AIDS, or an AIDS related disease. Six focus groups were held in Motherwell, Port Elizabeth ( $\mathrm{n}=$ 47) and six in KwaNobuhle, Uitenhage $(n=42)$. Each focus group consisted of six to nine participants and was facilitated by a trained isiXhosa speaking facilitator. The selected sample of elderly caregivers was invited to participate in this study by the community health workers who located them either at their homes or during their attendance at a community activity. The focus group discussions were held at the community health centers in the areas where the elderly lived and where they normally attended the usual activities provided by a local non governmental organization (NGO) - Age-in-Action, who was a partner in this study.

Nine community health workers, who were involved in selecting and inviting the elderly, were recruited through Age-inAction for the purpose of facilitating the focus group discussions. The community health workers were all female, first language isiXhosa 
speaking, and lived in the same areas as the elderly. The facilitators received an intensive three day training programme where they were taught specific skills to conduct the focus groups. Techniques they were taught included active listening, probing and summarizing, which are important aspects of moderating a focus group discussion (Krueger, 1998). These community health workers acted as facilitators for previous focus group discussions conducted by the Medical Research Council.

\section{Measures}

An interview schedule with semi-structured open-ended questions was developed to gather in-depth information on several themes. These included the demographic characteristics of the participants, their health status, their access to health care, the types of care the elderly provided to the members in their household, the physical, emotional, psychological and economic impact of caregiving on the participants, the facilitating and inhibiting factors of care that they experienced, and their thoughts about HIV and AIDS and young people of today.

The selection of research themes were based on a pre-study workshop with twenty community health workers who were actively involved in care and support for the elderly. The workshop revealed that elderly in their communities experienced multiple difficulties due to the many deaths among their children, the various responsibilities for those left in their care, and the lack of financial means. The findings from these discussions together with issues derived from the literature (see above) informed the broad themes for the focus group discussions. The interview schedule was developed with English speaking researchers and isiXhosa speaking community health workers. It was then translated in isiXhosa by first language isiXhosa speaking research assistants and subsequently back translated into English by a second set of research assistants to ensure face validity. The interviews where conducted in isiXhosa. 


\section{Data Analysis}

The data were transcribed in isiXhosa and translated in English by research assistants who were first language isiXhosa speakers. The accuracy of the translations was checked randomly by other first language isiXhosa researchers and research assistants. The transcriptions were managed by using Atlas.ti 5.2, a computer program for qualitative data analysis. The package allows for data to be searched systematically, coded and segmented according to the themes that emerge, which form the units of analysis. In describing the focus group results we aimed to generalize the often detailed, personal information to a higher level of abstraction to derive important lessons for future intervention programs. Citations from the study participants are used to illustrate the findings and to enhance an in-depth understanding of the perspective of the elderly.

The South African Medical Association Ethics Committee gave ethical approval for the study. The elderly were informed about the aims and purpose of the study in detail both verbally as well as in writing before consent was obtained.

\section{Findings}

\section{Demographic profile}

Among the 89 elderly, 60 were over the age of 65 years. Most of the participants were female (82), 46 were widowed, 28 were married and living with a partner, nine were single and six were divorced or separated. In terms of education, most participants (55) attended school, of which 19 completed lower primary, 16 completed higher primary, 16 completed junior secondary/high school, five completed senior secondary/high school and one had a degree in higher education. See Table 2.1 for a complete overview. 


\begin{tabular}{|c|c|c|}
\hline & Females (n) & Males (n) \\
\hline \multicolumn{3}{|l|}{ Age } \\
\hline Between 60 and 64 years $(n=29)$ & 29 & - \\
\hline Over 65 years $(n=60)$ & 53 & 7 \\
\hline Gender $(n=89)$ & 82 & 7 \\
\hline \multicolumn{3}{|l|}{ Marital status } \\
\hline Married $(n=28)$ & 24 & 4 \\
\hline Single and not married $(n=9)$ & 9 & - \\
\hline Divorced or separated $(n=6)$ & 6 & - \\
\hline Widowed $(n=46)$ & 43 & 3 \\
\hline \multicolumn{3}{|l|}{ Schooling } \\
\hline Once attended school $(n=55)$ & 51 & 4 \\
\hline Never attended school $(n=34)$ & 31 & 3 \\
\hline \multicolumn{3}{|l|}{ Level of education } \\
\hline Lower primary $(n=19)$ & 15 & 4 \\
\hline Higher primary $(n=16)$ & 16 & - \\
\hline Junior secondary/high school & 16 & - \\
\hline$(n=16)$ & 5 & - \\
\hline Senior secondary/high school & 1 & - \\
\hline$(n=5)$ & 2 & - \\
\hline Degree $(n=1)$ & & \\
\hline Missing & & \\
\hline
\end{tabular}

\section{Living conditions}

Most elderly in this sample live in an extended family situation with their own children and/or grandchildren and sometimes with the children or grandchildren of their siblings or other family members, as well as abandoned children. The description of their siblings' grandchildren as their own grandchildren reflects their conception of the role and meaning of the extended family. This appears to be a task that they shoulder regardless of their health, income or limitations regarding accommodation.

In most instances the elderly became the heads of the household as their spouses passed on and reported carrying out what appeared to be dual parenting roles, as parents to their children as well as their grandchildren. Their own adult children, although young, are 
frequently unemployed or sick, and unable to care and provide for themselves.

Most elderly became responsible for their grandchildren because of the death of one or both of their grandchildren's parents. In other instances the living parent of the grandchildren could not be traced for care or support of the child and with no other resources available, the grandparent would take up responsibility for the grandchild. This phenomenon of absent parents appeared to be prevalent in the area resulting in the frequent occurrence of single headed grand-parenting homes with little or no assistance.

\section{The patterns of care provided by the elderly}

General care responsibilities. In this study, elders were found to carry out a wide range of care activities. They felt responsible for meeting the needs of their children, grandchildren and other dependents and provided food, clothing, education, medical and emotional support. Apart from the responsibility towards others, most elderly reported that they had to take care of themselves as well as their spouses in everyway. This included doing household chores, such as cooking, cleaning and laundry, but also seeking medical treatment and supporting each other. Most elderly in this study were also the primary breadwinners in the household. Their most important source of income was their pension grant and some of them received money from their surviving children to supplement the family income. There were some who engaged in additional tasks to further supplement the family income as illustrated by one of the participants: "I sometimes do needle work so as to increase the pension money. I tried to farm some chicken. I bought two and those two expanded into thirteen chickens. But the other one was just stolen last week. I was away with church so I wanted to feed the chickens that are left in order to sell them to help my children that are at school. I am also in the elderly society at the clinic, there they teach how to sew." Elderly female respondent from Uitenhage. 
Specific care activities related to grandchildren. The elderly caregivers reported having to tend to the needs of their school-going grandchildren with respect to fees, food, clothing, and medical needs: "Alright, as I have the grandchild who is at school, I am supposed to wake up early in the morning and see to it that she eats and she is neatly dressed. When I am done, I have to see to the pot so that when she comes back from school she gets food, and also the supper is on me." - Elderly female respondent from Motherwell. Other grandparents were taking care of very young grandchildren and had to wake up at irregular hours and provide care for babies in the middle of the night, as well as washing, feeding and changing them. Furthermore the elderly indicated to feel responsible for the emotional well-being of their grandchildren, as one grandmother states: "Even when they are back it is the same thing: How is your homework, what happened at school today and what did you do." - Elderly female respondent from Motherwell. In addition, elderly provide emotional support for their grandchildren whose parents are ill or have passed away. Most elderly reported to be fully financially responsible for buying all necessities for their grandchildren, such as food, clothes, school uniforms, school books, medicines, as well as school fees, transport and doctor visits: "This child who is doing standard three, she always wants money, saying it is needed at school. So now I have to share this pension money in those things and I sometimes do not have that kind of money. I am struggling." - Elderly female respondent from Uitenhage.

Specific care activities for sick adult children. The elderly report to provide physical, emotional and financial care for their ill or disabled adult children, frequently infected with HIV or suffering from AIDS. The elderly describe some of the physical activities they engage in such as bathing the sick, as well as assisting them to get out of bed, to walk, to go to the toilet, to administer medication, to feed and to prepare healthy food. In addition, the elderly take responsibility to seek treatment for their sick children, arrange transport and take 
them to the health care services. Other tasks the elderly mentioned included giving emotional and social support: "You have to give her strength, tell her that all the children do get this thing (HIV), she is not the only one who is like that. You have to give her strength, always stay by her side and give her strength... tell her friends to come and talk to her; to come and help her in the house; ask them "have you seen her today?" Until her last day comes." - Elderly female respondent from Motherwell. Furthermore, many respondents find themselves in situations where they are expected to care financially for their children who are at the height of their economically productive years, but unable to fulfill these responsibilities due to ill health. This is irrespective of children staying with the elderly or on their own: "My third grandchild does not have a mother, she passed away. My other son is staying with his children and he is not working. I am expected to divide the pension money and support him." Elderly female respondent from Uitenhage.

\section{Support and community networks available to the elderly}

State Grants. A minority of elders reported being supported by their children or grandchildren. Most of the elderly in the study desperately depended on their monthly government grants of R740 (approx. 100 USD), to support themselves and their entire family. However there are some elderly who did not have access to these state grants due to the lack of money for transport or lack of and assistance with the completion of the grant-application. With regard to accessing a grant for their grandchildren, the elderly in this study reported experiencing many difficulties. Elderly sometimes cannot trace the living parents for necessary documents, resulting in an incomplete application and being sent home without being helped. "Because their mother passed away November last year, and I made the application for the foster care grant this year February, but I did not get it yet, because they said I must go to the fathers of these children of which I do not know their whereabouts." - Elderly female respondent from 
Motherwell. Some elderly indicated to receive assistance from social workers in applying for a grant. However, frequent dissatisfaction was expressed, since many social workers were believed to help to an insufficient extent.

Medical Support. The elderly in this group indicated that they suffered from a variety of physical health problems as a result of their age, such as arthritis, high blood pressure, diabetes, eyesight problems and poor limbs. The elderly also experienced psychological problems which resulted from their responsibilities as caregivers and included stress, worries, hurt and grief, often resulting in insomnia. However, they also express great dissatisfaction with the medical health services available.

Within the particular study area the clinics and hospitals were situated in close proximity and were easily accessible to most of the elderly. However due to safety issues in the area as well as age, mobility and time constraints, the elderly continued to experience accessibility problems: "No, me, I take the public transport I will never go on foot waking up early. I told them that I will never allow the rapist to rape me in the morning and these children can also hit you, these boys can harm you at that time and they think that you have money with you in your bag although it's just my card." - Elderly female respondent from Motherwell. Several of the elderly indicated that arriving late at the clinic due to transport problems had consequences of being sent home without treatment, as one elderly stated: "The hospital that I go to is Livingstone. I have to hire a car because I can't walk and you have to be early at the hospital. If you are late you are sent back home." - Elderly female respondent from Motherwell. Furthermore, paying for transport often infringes on the elders' limited finances and results in not being able to keep appointments.

A great majority of the elderly expressed dissatisfaction about the medical facilities and the support they received when they sought medical care for themselves. Some of the grievances mentioned by 
them were an inadequate supply of medication and insufficient information from the medical staff, both doctors and nurses, about the nature of their personal health complaints. Also dissatisfaction about the appointment system was expressed. Frustrations were expressed about being turned away from the clinic despite arriving on time. This often occurred after hours of waiting in the queue due to only a certain quota of patients receiving attention. In general, a lack of faith in doctors and nurses and distrust towards the hospitals and clinics was expressed by the elders in this study: "We are not satisfied my child. It is even worse when you go to the hospital. You get the high blood pills and told that the ones for the bones are not available. When you say "I have a headache" you are told that there are no headache tablets and you are given three panados. That is all." - Elderly female respondent from Motherwell. An interesting phenomenon in this respect is the confusion that was expressed by some elderly about seeking help from traditional healers: "We are not satisfied at all as the mothers are saying. This money is not enough. Because when you go to the hospitals you are told to go to the traditional herbs (emhlonyaneni). I get surprised now because back then we were told to forget about the traditional herbs. You were told to rush to the nurses in the clinic even if you feel a small pain. Now we are told to go back to the traditional medicines. I ask myself why we are told to go to traditional herbs when we used to be told not to use them. We were told to rush to the clinic. Now we are told to go back to these herbs and we wonder what is new." - Elderly female respondent from Motherwell.

Support from the community. Despite their commitments to children and additional tasks, some of the elderly in this study were able to socialize in a way that is meaningful to them. This included going to church, to elderly clubs and to "stokvels" (financial support groups). They also mention spending time sewing, gardening, socializing with people their own age as well as carrying out community work. These activities are reported as being enjoyable and 
gave a sense of normality and relaxation in their lives. "We also have a club and this loneliness inside do get away. On Sunday I go to church and I also do feel very much happy on Thursdays because you feel free to talk to the mothers there and you feel much relieved afterwards." - Elderly female respondent from Motherwell. The elderly also reported providing psychological and emotional support for each other by talking about their problems. In doing this they were mindful of keeping confidentiality and fostering trust. Conversing with and sharing each others' problems provided a cathartic effect for the elderly as they expressed feeling relieved after verbalizing their problems. "I have my neighbor. When I have a problem I go to my neighbor, irrespective of what the problem is. I don't share my problems with just anybody." - Elderly female respondent from Uitenhage. Talking with others about their problems also appeared to provide the elderly with the opportunity to identify with and relate to similar experiences of others. They often prayed together about their problems. Prayer seemed to be a source of comfort and strength that the elderly could identify with.

\section{Economic effects}

School-related finances are regarded as the biggest burden for the elderly when they take care of their younger grandchildren. Many elderly reported that they experienced difficulties in paying school fees and sometimes had to take their grandchildren out of school: "I am the one who is providing for the child's education, but this year the child could not go to school because of financial constraints, because I could not afford the school needs, the child stopped in January and was doing standard eight." - Elderly female respondent from Uitenhage. The elderly indicated that medical costs such as transport to health facilities and medicines are seen as another high expenditure, as well as funeral costs. To cover costs, participants mention that they have to borrow money from loan lenders or when possible from people in their surrounding, like neighbors. Loan 
lenders however demand high interest rates, which increases the burden that the elderly carry. "I have a child and I was unable to go to her funeral, it's my sister in law's child whom I brought up when she was four till she got married, she was sick but her husband passed away before her... (she cried)...now I was unable to go to her funeral, I don't have money, but in September I hope I'll go and seek for her child... (she cried much louder)... What makes me even more painful, I didn't go to her husband's funeral and not even to hers...it's because I don't have money, all my money I've given to cash loaners, it's even difficult for me to go to Kimberly." - Elderly female respondent from Uitenhage.

\section{Psychological effects and role reversal}

The hurt and pain of looking after their own children due to illnesses such as HIV and AIDS and other diseases has been observed to be a painful and traumatic experience for the elderly. Some of the elderly broke down and cried when they related the plight of their sick or deceased children. They expressed having to endure the pain of losing a child without proper bereavement, an adjustment period and proper counseling as they have to be emotionally and physically strong to support their grandchildren that have been left behind as a result of a parent's death. "There is no parent who rests. Our problem as parents is that these children go to the graveyard almost every day; they are dying. The pain is with us when we are talking." - Elderly female respondent from Uitenhage. Other elderly in this study expressed that they suffered from stress and worries on how to make ends meet as they were financially dependent on their children before they got sick and passed away. "In 1997 my nerves started when my daughter passed away... The stress, it's the child that I was depending on, that she will be able to bury me and she grows and do these things for me, you understand." - Elderly female respondent from Motherwell. 
The elderly in some instances were frustrated and disappointed that they had to support their unemployed children and that the roles were reversed. The elderly find themselves in situations where they are expected to care for their children who were supposed to be at the height of their economically productive years and taking care of them. Instead their children are unable to fulfill these responsibilities due to illnesses and death. "We never thought that it is going to be like that. We raised ours, now we have to raise the grandchildren in difficulties. In the current age of us, we are going to die maybe while they are still young, not able to do anything for themselves. When you think about that your heart becomes sore. Look, now you're raising the grandchildren, do you hear me? I am telling you that I have grandchildren of a year old. There is one of one year old and the other one is five years old. I am starting at the beginning whereas I was supposed to be resting with the children are looking after me." Elderly female respondent from Motherwell.

Many elderly expressed to be fearful and plagued with the thought that their children and/or grandchildren might have been infected with HIV or do have AIDS due to the way the youth conducts their sexual practices: "Now our children are infested with AIDS. They learn, we educate them, but day-in and day-out a child is going up and down with a boy." - Elderly female respondent from Uitenhage. The elderly expressed the feeling that they had no control over HIV and AIDS as their children were engaging in unsafe sexual activities at a younger age with multiple partner relationships despite the fact that they could contract the virus and become pregnant. "Firstly, our children cannot be told anything, because if they could start having sexual related things at the age of 18, I think that would be much better. Now they are starting those things while they are still under age and that thing is condemning them. I see this as the most difficult thing." - Elderly female respondent from Motherwell. 


\section{Inter-generational interactions and divide}

The elderly expressed a sense of hopelessness with matters related to the youth they care for. They perceive disrespect, stubbornness and a general "don't care attitude" towards life and physical health in the youth. "She's a problem at home. When you are talking with her, she's in a hurry and leaves by the door. She's cheeky. She'll act like she is going to school but she's not going to school. She'd rather leave if you've tried to discuss her behavior with her." Elderly female respondent from Uitenhage. Some of the elderly felt that a huge part of the younger generation is involved in alcohol consumption, unsafe sexual behavior and staying out whole nights, as one grandmother expressed: "Our children do not sleep, on Fridays at 6pm they go out and say they are going to night shifts. They'll come back at 4am or even at 7am, and they'll be very drunk." - Elderly female respondent from Uitenhage.

The youth were depicted by many of the elderly as arrogant and having an irresponsible attitude towards HIV and AIDS. Elderly expressed their concern about this indifferent attitude of the youth and in particular about the girls. They reported that the girls are disrespectful to their bodies, they are lazy, and they do not contribute to chores at home, change relationships regularly and have an affinity for men who support them financially or provide them with alcohol. They also felt that many youth that have contracted the "virus" tend to hide their health status from their caregivers until it is too late and they are in the stages of dying from the disease. "She 'll say that she comes from school, but she was with a boy. From there she'll wed that boy, stay with that boy, she doesn't want to abide by the rules at home. She comes back when there's a problem-AIDS; an incurable disease. And she won't even tell you, instead she'll go around telling other people (...) she's your child; you'll forgive her when she has that disease." - Elderly female respondent from Uitenhage. 
The elderly feel that the behavior of the youth has become an added burden and concern, as many of them have lost their own children to HIV and AIDS and feel helpless as the same is happening to their grandchildren. The elderly feel no connection with the youth as this generation differs so vastly from their own. They continuously compare the respect they had for their parents with the respect shown by today's youth towards them. They expressed being extremely proud of their own values, rituals and beliefs they grew up with and wished that the youth would take their advice or listen to what they have to say.

\section{Discussion}

The findings of this study demonstrated that caring for sick children and/or orphaned grandchildren causes hardship for many elderly people who are grandparents. With limited resources and support, the elderly find themselves continuing an active parenting role in addition to having to meet the needs of their family in all respects: financially, emotionally and physically. These responsibilities although shouldered with dignity and pride challenge the financial, emotional, social and physical condition of the elders.

While many grandparents in the present study indicated that the care they provided was done out of love, familial and community ties, they clearly articulated their difficulties. These included contextual difficulties such as a serious lack of financial support and difficulties accessing pension and other grants. Existing studies confirm these financial difficulties and indicate that pensions are often the only source of income and are shared among households with multiple dependents (Schatz \& Ogunmefun, 2007). While other studies confirm difficulties among the elderly in obtaining grants, mostly due to the lack of relevant documents required for a successful grant application (Schatz \& Ogunmefun, 2007; Case \& Menendez, 2007). Expansion of the South African pension system and 
improvements in accessing grants seem to be urgently needed, especially since research and the present study has shown that pension grants among elderly plays a significant role in the improvement of children's health and development (Case \& Menendez, 2007; Duflo, 2003).

Other difficulties that were found consisted of the lack of support in providing care-related tasks. As a consequence, this study and another recent study (Schatz, 2007) illustrates that young children find themselves in a situation in which they are providing domestic and health care assistance to their sick parent/s and grandparents. This places a strain on young children as well as the elderly, since the young children are fully dependent on their grandparents to facilitate their development and growth.

Further, the elderly expressed difficulties in coping with issues of parenting and communication with grandchildren in a modern environment. The findings of this study further showed that the modern social environment creates a generation gap which reflects a dissonance in values that are expected by the elderly and the actual behaviors that young people engage in. The features of this generation gap are reflected in the elderly's expression of an inability to cope with, for example, youth's multiple sexual relationships or a lack of social etiquette. They fear that the young people of today are growing up in an environment that lacks discipline, guidance and insight into planning for a better and more successful future for themselves and appeared to be repeating their parents' mistakes. Additionally the elderly seem to indicate that the breakdown of traditional norms and cultural practices is a major contributor to the burden of disease and care, a conclusion which was also drawn in a study by Posel, Kahn, \& Walker (2007).

Elderly further suffered from emotional stress from multiple deaths in their families and an inability to grieve because of the pressing needs of their remaining dependents, thus impacting negatively on their ability to cope. Other studies have found that the 
elderly felt that their efforts and resources spent on caring for someone with AIDS was 'wasted', leading to emotional stress and worries about now and the future (Ssengonzi, 2007). In this study, elderly also experienced emotional stress and disappointment as they expected that children will one day take care for them, whereas the roles are now reversed and the elderly are now the ones to care for their children (see also Schatz, 2007).

Finally, this research and other studies (Ndaba-Mbata \& Seloilwe, 2000; Ssengonzi, 2007) demonstrate that the elderly expressed difficulties in providing physical nursing care for their sick adult children. Due to their own physical health problems as a result of their old age, lack of knowledge and nursing supplies, they are often not able to provide their children with the adequate care they need, particularly in advanced stages of AIDS. Therefore, elderly expressed a need for more information and support to care for children who are infected with HIV/AIDS. Although many elderly in the focus group discussions were able to talk freely about topics related to HIV and AIDS, the language and terms they used were very general and often AIDS was being referred to as 'this disease' or elderly would start whispering. This shows that AIDS and AIDS-related topics are not as yet comfortable subjects for public conversation, probably due to the lethal nature of the disease (Posel, Kahn, \& Walker, 2007). In discussing the needs of the elderly with specific reference to care it became apparent that there is a call for more information regarding the prevention of AIDS, its progression, its treatment and nursing care including issues of infectivity.

\section{Conclusion}

This study highlights the expanding changing role of elderly and their responsibilities and challenges as care-givers of children and grandchildren as a result of HIV and AIDS. Elderly fulfill a wide range of responsibilities with a minimum of resources, assistance and 
support and suffer major economic, psychological and social consequences as a result.

More research is needed to further understand and quantify the extent to which the elderly are providing care for their dependents as well as how they are affected by their care responsibilities. More specifically, future research should include theoretical constructs from behavior change theories, such as attitudes, self-efficacy, social norms and knowledge with respect to caring to explain and understand the behavior of elderly as providers of care. Furthermore, forthcoming studies should focus on the psychological impact of care on the elderly and psycho-social constructs such as coping, depression or grief and bereavement, and perceived stigma related to HIV and AIDS should be included. Besides, as the care provided by the elderly has far reaching economic impacts, future research should also include this. Additionally, future research should comprise quantitative information on support available to the elderly, as well as information on quality and availability of health care services as perceived by the elderly. Subsequently this information should be used to inform the development of supporting structures. 


\section{Chapter 3}

Correlates of Grief among Older Adults

Caring for Children and Grandchildren as

a Consequence of HIV and AIDS in South

Africa

\section{Based on:}

Boon, H., Ruiter, R.A.C., James, S., van den Borne, B., Williams, E., Reddy, P. (in press). Correlates of grief among older adults caring for children and grandchildren as a consequence of HIV and AIDS in South Africa. Journal of Aging and Health. 


\section{Introduction}

In South Africa, one of the most important current social and public health challenges is the HIV and AIDS epidemic. A 2007 report from the Department of Health estimated that over 5.4 million South Africans are HIV infected (Department of Health, 2007). The HIV prevalence among people aged 15 to 49 years was estimated to be $18.3 \%$. These high infection rates place a heavy burden of care on the health system and society in general. Many people become chronically ill as a result of HIV and AIDS, and need care over extended periods of time. Health services are unable to accommodate the increasing numbers of patients, which obliges families to take care of their chronically and terminally ill relatives at home (Ndaba-Mbata \& Seloilwe, 2000).

Several studies have shown that older people are most often the main caregivers and need to take responsibility for the physical, emotional and economic needs of their HIV-infected adult children (Boon et al., under review; Freeman \& Nkomo, 2006; HelpAge International, 2003; Knodel \& VanLandingham, 2002; Ntozi \& Nakayiwa, 1999; Nyambedha, Wandibba, \& Aagaar-Hansen, 2003b; Reddy, 2005; Schatz, 2007; Ssengonzi, 2007). In addition, when adult children get sick and die, they leave behind orphans who rely on the care from the community and extended family. An increasing number of older persons, usually older women, are taking care of their sick adult children and are also taking full responsibility for raising young grandchildren, often with little or no support from family or friends (Foster, Makufa, Drew, Kambeu, \& Saurombe, 1996; HelpAge International, 2004; Juma, Okeyo, \& Kidenda, 2004; Kipp, Tindyebwa, Rubaale, Karamagi, \& Bajenja, 2007b; Ntozi, 1997b; Nyambedha, Wandibba, \& Aagaar-Hansen, 2003b; Ssengonzi, 2007; UNICEF, 2003; World Health Organization, 2002).

The challenges that older persons face as a consequence of being caregivers and losing their adult children are manifold. 
Financially, older adults struggle as their adult children are no longer able to provide them with support (Moore, 2008). Furthermore, old age pensions in South Africa are commonly the only source of household income, and are unable to cover all living, medical and schooling expenses for themselves and their dependents (HelpAge International, 2004; Schatz, 2007; Schatz \& Ogunmefun, 2007; Ssengonzi, 2007). Emotionally and psychologically, older adults suffer from feelings of distress, anxiety, depression, helplessness and hopelessness as a result of their care-giving responsibilities and loss of loved ones (Boon et al., under review; Knodel, 2005, Ndaba-Mbata \& Seloilwe, 2000; Nyambedha, Wandibba, \& Aagaar-Hansen, 2003b; Reddy, 2005; Ssengonzi, 2007). Due to the physical demands of providing care to their sick dependents, and with considerations for their own health and well-being with increased age, older adults are likely to face considerable physical constraints (Appleton, 2000; Dayton \& Ainsworth, 2004). At the same time, social isolation often increases as caring duties require substantial amounts of time that take older caregivers away from their usual livelihood and social activities (Orner, 2006; Thomas, 2006).

To the best of our knowledge, no studies have been conducted on the psychosocial and environmental predictors of grief among older caregivers as a result of HIV and AIDS in the South African context. Grief can be defined as the affective reaction to stressful life events (Stroebe, Hansson, Stroebe, \& Schut, 2001). In response to the death of a child, parental grief is believed to last longer and be more complicated than loss of any other family member, even a spouse (Middleton, Raphael, Burnett, \& Martinek, 1998; Moore, 2008). Bereaved people are more likely to have a wide range of physical as well as psychological health problems (Stroebe, Schut, \& Stroebe, 2007). In addition there is risk of more intense grieving when the cause of death is stigmatised, as is commonly reported for AIDSrelated deaths (Aranda \& Milne, 2000). Stigma may contribute to isolation out of fear of the consequences of disclosing the cause of the 
death of ones' child, and may result in older caregivers' not receiving the much needed social support (Moore, 2008).

Identifying the key psychosocial and environmental

components of grief for older caregivers is necessary to develop effective interventions that alleviate the impacts of HIV and AIDSrelated caregiving on the lives of older persons. The present study focuses on the experience of grief among older adults caring for children and grandchildren as a result of HIV and AIDS and identifies correlates of grief to inform future interventions to assist care givers in coping with their responsibilities.

\section{Method}

\section{Participants and Setting}

The study sample consisted of isiXhosa-speaking adults aged 60 years and older who provided daily care to children or grandchildren as a result of HIV and AIDS. The sample was drawn from Uitenhage and Motherwell, informal settlements from the Nelson Mandela Metropole in the Eastern Cape Province of South Africa. These areas are predominantly Xhosa speaking, have high rates of unemployment, poor living conditions and had a high HIV infection rate of $28.6 \%$ among antenatal clinic attendees in 2006 (Department of Health, 2007; Eastern Cape Provincial Government, 2008). The African (black) population is most affected by HIV in this area with a prevalence of over 83\% (Development Partners, 2007). For this reason the study focused on the care responsibilities of older persons of African descent.

In total, 820 older persons from Motherwell $(\mathrm{N}=488)$ and Uitenhage $(\mathrm{N}=332)$ completed the survey. Sixty-five respondents (7.9\%) were excluded from the analyses because they were not caregivers $(\mathrm{N}=38)$, did not identify themselves as having an African background $(\mathrm{N}=16)$, or had a missing value for either one of those 
variables $(\mathrm{N}=11)$. This resulted in a final sample of 755 respondents. The majority of respondents were female, aged 60 to 69 years old and widowed. Most respondents had no formal education and received a monthly income of less than R1000 (approx. 120 USD) mainly through an old age government grant. See Table 3.1 for the demographic characteristics of the study sample.

\section{Procedure}

Community health workers who were employed by Age-inAction, a local non-governmental organisation and partner in this project, were involved in recruiting participants and collecting data. All community health workers were female, spoke isiXhosa as their first language and lived in the same community as the participants. Through their extensive knowledge of the area and work experience with Age-in-Action, the health workers were able to access older caregivers in the community.

The community workers received an intensive one-day training in which they were taught in a participatory manner how to invite participants to take part in the study, how to obtain informed consent, how to ask questions, how to record responses on the answering sheets and how to complete the interview register.

All eighteen trained community health workers (nine in Motherwell; nine in Uitenhage) approached caregivers at their homes, informed them about the study, and invited them to participate. Community health workers conducted one-on-one interviews. All interviews were done in isiXhosa, the first language of both the participants and the interviewers. Mean interview time was 2.5 hours, including a tea and lunch break. The interviews took place in community halls in separate rooms or alternately, in the home of the respondent. At the end of the interview, respondents were provided with a meal and a small gift. 
Table 3.1: Demographic variables of older caregivers $(N=755)$

\begin{tabular}{|l|c|}
\hline Demographic variable & $\mathbf{( N , \% )}$ \\
\hline Age & $192(25.4 \%)$ \\
\hline $60-64$ years & $212(28.1 \%)$ \\
$65-69$ years & $155(20.5 \%)$ \\
\hline $70-74$ years & $100(13.2 \%)$ \\
\hline $75-79$ years & $94(12.5 \%)$ \\
\hline 80 years or older & $2(0.3 \%)$ \\
\hline Missing & \\
\hline Gender & $85(11.3 \%)$ \\
\hline Male & $663(87.8 \%)$ \\
\hline Female & $7(0.9 \%)$ \\
\hline Missing & \\
\hline Marital status & $147(19.5 \%)$ \\
\hline Married & $74(9.8 \%)$ \\
Single & $69(9.1 \%)$ \\
\hline Divorced & $463(61.3 \%)$ \\
Widowed & $1(0.1 \%)$ \\
\hline Missing & \\
\hline Education & $308(40.8 \%)$ \\
\hline Attended school & $447(59.2 \%)$ \\
\hline Never attended school & \\
\hline Highest level of completed education & $123(16.3 \%)$ \\
\hline Lower primary school (Sub A - Standard 2) & $114(15.1 \%)$ \\
\hline Higher primary school (Standard 3 - 5 & $50(6.6 \%)$ \\
\hline Junior secondary school (Standard 6 - 7) & $22(2.9 \%)$ \\
Senior secondary school (Standard 8 - 9) & $5(0.6 \%)$ \\
\hline Matric (Standard 10) or further studies & $441(58.4 \%)$ \\
\hline Missing & \\
\hline Employment & $88(11.7 \%)$ \\
\hline Employed & $664(87.9 \%)$ \\
\hline Unemployed & $3(0.4 \%)$ \\
\hline Missing & \\
\hline & \\
\hline
\end{tabular}




\begin{tabular}{l|c}
\hline Demographic variable & $\mathbf{( N , \% )}$ \\
\hline Monthly income & $59(7.8 \%)$ \\
R0 & $643(85.2 \%)$ \\
Less than R1000 & $38(5 \%)$ \\
Between R2000 - R5000 & $6(0.8 \%)$ \\
More than R6000 & $9(1.2 \%)$ \\
Missing & \\
\hline Main source of income & $3(0.4 \%)$ \\
Paid job & $9(1.2 \%)$ \\
Family member or friend & $687(91 \%)$ \\
Old Age Grant & $36(4.8 \%)$ \\
Other social grant (not Old Age Grant) & $20(2.6 \%)$ \\
\hline Missing & \\
\hline
\end{tabular}

Detailed information about the content, procedures and confidentiality of the study was provided both verbally and in writing before consent was obtained. Ethical approval for the study was given by the South African Medical Association Ethics Committee.

\section{Measures}

Based on foregoing qualitative research (Boon et al., under review; Reddy, 2005), existing literature, and social cognition models of human behaviour (Connor \& Norman, 2005), a measurement instrument was developed. The questionnaire was pre-tested among community health workers from Motherwell and Uitenhage. All questions were studied thoroughly one by one and were inspected for cultural relevance and appropriateness. Questionnaires were translated into isiXhosa and back-translated into English by first language isiXhosa researchers to ensure quality assurance.

Socio-demographic questions were asked to illicit age, gender, relationship status, monthly income and number of dependents. Table 3.2 provides an overview of the psychosocial concepts that were measured, including sample items, the number of items, minimum and maximum score, and Cronbach's alpha $(\alpha)$. Validated instruments 
were used to measure grief (i.e., Anticipatory Grief Scale; Theut, Jordan, Ross, \& Deutsch, 1991), depression (i.e., Geriatric Depression Scale; Yesavage et al., 1983; Brink et al., 1982), coping (i.e., Ways of Coping; Folkman \& Lazarus, 1985; Folkman, Lazarus, DunkelSchetter, DeLongis, \& Gruen, 1986) and stigma related to HIV and AIDS (i.e., HIV stigma scale; Berger, Ferrans, \& Lashley, 2001). The validated scales that were used all have been tested in study settings that differ to a large extent from this particular study setting. This sample is largely poorly educated, answered the items in an interviewformat rather than a self-report format, and were older respondents. Therefore it was important to check the scale structures and psychometric properties for this population and context. Factor analysis was used to check the sub-structure of the scale and reliability analysis to check the resulting internal consistency of scores on items within subscales. For the Anticipatory Grief Scale, factor analysis determined one main scale and two smaller subscales. The items in the subscales were removed from the main scale after studying the content of the subscale items, which differed and could not be put in one subscale. Five items were removed from the Geriatric Depression Scale after factor analysis and studying of the factor loadings. The scores of the scale were summed up and then regarded as one index of depression (range $0-10$ ). The original Ways of Coping Checklist suggests six subscales, however this structure was not supported by factor analyses. Instead two subscales were proposed and subsequently derived with passive and proactive ways of coping. The original Stigma related to HIV and AIDS scale was divided in four subscales, however factor analysis did not confirm the original subscales and due to high collinearity between the different subscales (rs ranged from 82 to .94), it was decided to combine the items into one scale. For each measure, scores on separate items that showed sufficient internal consistency (Cronbach's alpha $[\alpha]>.65$ ) were averaged into one single index (unless otherwise indicated). Higher scores reflect a stronger presence of the concerned variable. 
Table 3.2: Overview of scale measures

\begin{tabular}{|c|c|c|c|c|}
\hline Measure and example items & $\begin{array}{c}\text { Number } \\
\text { of } \\
\text { items }\end{array}$ & $\begin{array}{l}\text { Min } \\
\text { score }\end{array}$ & $\begin{array}{l}\text { Max } \\
\text { score }\end{array}$ & $\begin{array}{l}\text { Cronbach's } \\
\text { alpha ( } \alpha)\end{array}$ \\
\hline $\begin{array}{l}\text { Grief } \\
\text { - I feel very much along since the passing of } \\
\text { my child } \\
\text { - I am unable to accept the fact that my } \\
\text { child passed away }\end{array}$ & 16 & 1 & 5 & .97 \\
\hline $\begin{array}{l}\text { Depression* } \\
\text { - Do you feel happy most of the time? } \\
\text { Do you often feel helpless }\end{array}$ & 10 & 0 & 1 & $\mathrm{n} / \mathrm{a}$ \\
\hline $\begin{array}{l}\text { Coping**: } \\
\text { Passive coping } \\
\text { - How often in the past three months have } \\
\text { you: tried to keep your feelings to } \\
\text { yourself? } \\
\text { - Hoped that a miracle would happen? }\end{array}$ & 8 & 1 & 4 & .90 \\
\hline $\begin{array}{l}\text { Proactive coping } \\
\text { - How often in the past three months have } \\
\text { you: made a plan of action and followed } \\
\text { it? } \\
\text { - Talked to someone about your feelings? }\end{array}$ & 8 & 1 & 4 & .97 \\
\hline $\begin{array}{l}\text { Stigma related to HIV and AIDS } \\
\text { - I work hard to keep my child's HIV a } \\
\text { secret } \\
\text { - Most people with HIV are rejected when } \\
\text { others find out }\end{array}$ & 40 & 1 & 4 & .95 \\
\hline $\begin{array}{l}\text { Perceived responsibility to provide care } \\
\text { I feel that it is my responsibility to: } \\
\text { - Cook a meal for the family every day } \\
\text { - Help my child do his homework }\end{array}$ & 21 & 1 & 5 & .94 \\
\hline $\begin{array}{l}\text { Self-efficacy to provide care } \\
\text { How confident do you feel about: } \\
\text { - Bathing a sick person } \\
\text { - Appling for a grant for your child }\end{array}$ & 30 & 1 & 5 & .94 \\
\hline $\begin{array}{l}\text { Subjective norm towards providing care } \\
\text { My family and friends expect me to: } \\
\text { - Bring my child to school every morning } \\
\text { - Provide income for the family }\end{array}$ & 29 & 1 & 5 & .95 \\
\hline $\begin{array}{l}\text { Attitude towards young people } \\
\text { - I feel that the youth nowadays do not feel } \\
\text { proud of themselves } \\
\text { - I feel that the youth nowadays can not }\end{array}$ & 4 & 1 & 5 & .88 \\
\hline
\end{tabular}




\begin{tabular}{|c|c|c|c|c|}
\hline Measure and example items & $\begin{array}{c}\text { Number } \\
\text { of } \\
\text { items }\end{array}$ & $\begin{array}{l}\text { Min } \\
\text { score }\end{array}$ & $\begin{array}{l}\text { Max } \\
\text { score }\end{array}$ & $\begin{array}{l}\text { Cronbach's } \\
\text { alpha ( } \alpha)\end{array}$ \\
\hline \multicolumn{5}{|l|}{ stick to one partner } \\
\hline $\begin{array}{l}\text { Perceived control to provide care } \\
\text { How difficult do you find it to: } \\
\text { - Make youngsters obey the rules of the } \\
\text { house } \\
\text { - Exercise authority }\end{array}$ & 7 & 1 & 5 & .94 \\
\hline $\begin{array}{l}\text { Personal norm towards providing care } \\
\text { I feel it's my moral duty to: } \\
\text { - Provide funeral cover for the members in } \\
\text { the household } \\
\text { - Support my grandchild with the loss of his } \\
\text { mother/father }\end{array}$ & 9 & 1 & 5 & .99 \\
\hline $\begin{array}{l}\text { Knowledge about providing care* } \\
\text { - An open wound should be treated with } \\
\text { disinfectants } \\
\text { - A person on anti-retrovirals should take } \\
\text { medication at set times }\end{array}$ & 6 & 0 & 1 & $\mathrm{n} / \mathrm{a}$ \\
\hline $\begin{array}{l}\text { Experienced care-giving worries* } \\
\text { - Do you worry about what will happen to } \\
\text { your child when you're not here anymore? } \\
\text { - Are you afraid you're not able to meet the } \\
\text { needs of your child? }\end{array}$ & 2 & 0 & 1 & $\mathrm{n} / \mathrm{a}$ \\
\hline $\begin{array}{l}\text { Health status dependents } \\
\text { - The person can: get into bed by himself } \\
\text { The person can: use the toilet by himself }\end{array}$ & 8 & 1 & 4 & .98 \\
\hline $\begin{array}{l}\text { Perceived health status caregiver } \\
\text { - How would you rate your health? }\end{array}$ & 1 & 1 & 5 & $\mathrm{n} / \mathrm{a}$ \\
\hline $\begin{array}{l}\text { Perceived financial situation } \\
\text { How does being a caregiver affect your } \\
\text { financial situation? }\end{array}$ & 1 & 1 & 4 & $\mathrm{n} / \mathrm{a}$ \\
\hline
\end{tabular}

* Total scores comprised of the sum of individual items

** Two subscales were derived after factor analysis: proactive and passive coping

\section{Data Analysis}

The software package SPSS Version 15.0 (SPSS, Chicago, IL) was used to identify significant correlates of grief. Straight frequencies were conducted for demographic and descriptive 
variables. Bivariate correlations were calculated for the psychosocial variables and grief. Also bivariate regression analysis was done to confirm the significance of the correlates with grief. Hierarchal multiple regression analysis was conducted to explore the unique contribution of each variables in explaining grief among older people. Variables that showed significant bivariate correlations with grief were added to the model stepwise. The Enter method was used for this purpose, allowing all predictors to be entered simultaneously at each step. To control for possible differences between the two study sites, significant correlate $\mathrm{x}$ site interactions were included in the regression analyses. Subsequently simple effect analyses were conducted to determine for each site the influence of the correlate on the perceived feeling of grief. A significance level of 5\% was used throughout.

\section{Results}

\section{Caring Details}

Table 3.3 presents an overview of the care related details. The findings of this study indicate that older persons live in extended family situations with their children and grandchildren, and sometimes with several other dependants, such as the children and grandchildren of their relatives. Their adult children, although young, are in $21.9 \%$ $(\mathrm{N}=165)$ of the cases unemployed, sick $(\mathrm{N}=338 ; 44.8 \%)$ or have passed away $(\mathrm{N}=337 ; 44.6 \%)$. With little support from the surviving mother of the grandchild $(\mathrm{N}=37 ; 4.9 \%)$ and the other living grandmother $(\mathrm{N}=20 ; 2.6 \%)$, the full care and responsibility for grandchildren is left in the hands of the respondents. On average, each respondent cared for 4.58 (range 0 - 14) children, grandchildren and other dependents, of which 1.46 (range 0 - 14) dependents were sick. Eighty-six percent of older persons were responsible for looking after school-aged dependents, with an average of 2.02 children per older person and a range of 0 to 11 . 
Older persons were involved in a wide variety of care-related tasks. Besides taking care of themselves and their households, they were occupied with responsibilities such as bathing and dressing of sick adult children, taking children to the doctor, taking grandchildren to school and assisting them with their homework.

Table 3.3: Caring details and care-related activities of older caregivers $(\mathrm{N}=755)$

\begin{tabular}{|c|c|c|}
\hline Caring variables & (M, SD) & Range \\
\hline Total number of sick dependents & $1.46(2.06)$ & $0-14$ \\
\hline Total number of school-going dependents & $2.02(1.48)$ & $0-11$ \\
\hline $\begin{array}{l}\text { Number of people who had/have HIV or AIDS in } \\
\text { the household }\end{array}$ & $1.06(0.82)$ & $0-4$ \\
\hline Number of support services available & $1.95(1.42)$ & $0-6$ \\
\hline Number of care activities provided & $9.43(2.49)$ & $0-11$ \\
\hline Care activities & $(\mathbf{N}, \%)$ & \\
\hline $\begin{array}{l}\text { Household (e.g. cleaning, laundry, preparing } \\
\text { food) }\end{array}$ & $655(86.8 \%)$ & \\
\hline $\begin{array}{l}\text { Personal care (e.g. feeding, bathing, toileting } \\
\text { children) }\end{array}$ & $571(75.6 \%)$ & \\
\hline $\begin{array}{l}\text { Mobility (e.g. helping child to walk, get in/out } \\
\text { bed) }\end{array}$ & $492(65.2 \%)$ & \\
\hline $\begin{array}{l}\text { Transportation (e.g. via public transport, } \\
\text { wheelchair) }\end{array}$ & $487(64.5 \%)$ & \\
\hline $\begin{array}{l}\text { Companionship (e.g. accompanying child } \\
\text { anywhere: clinic) }\end{array}$ & $542(71.8 \%)$ & \\
\hline $\begin{array}{l}\text { Shopping (e.g. buy anything child needs: food, } \\
\text { clothing) }\end{array}$ & $680(90.1 \%)$ & \\
\hline $\begin{array}{l}\text { Financial guidance (e.g. pay accounts, decide } \\
\text { upon spending) }\end{array}$ & $707(93.6 \%)$ & \\
\hline $\begin{array}{l}\text { Nursing (e.g. dress wounds/bedsores, } \\
\text { administer medication) }\end{array}$ & $650(86.1 \%)$ & \\
\hline $\begin{array}{l}\text { Emotional (e.g. help child to deal with loss of } \\
\text { parent) }\end{array}$ & $721(95.5 \%)$ & \\
\hline $\begin{array}{l}\text { Educational (e.g. attend parent-teacher } \\
\text { meetings, homework) }\end{array}$ & $705(93.4 \%)$ & \\
\hline $\begin{array}{l}\text { Financial (e.g. apply for grant, provide extra } \\
\text { income) }\end{array}$ & $692(91.7 \%)$ & \\
\hline
\end{tabular}


Although some caregivers were receiving some kind of assistance from children or other family members in providing care, most were solely responsible for their dependents (88.2\%). Most participants $(89.7 \%)$ did not have a choice in taking up the care-giving role as there was no one else to provide care for the sick and dependent. The majority (73.6\%) lost someone from their household to AIDS or to an AIDS-related illness. The deceased dependent was the main breadwinner in over half of the households $(56.7 \%)$, leading to severe financial problems. Participants expressed suffering financially under the responsibilities as caregiver, and $94.2 \%$ of caregivers reported running out of money completely.

\section{Grief and Correlates of Grief}

The majority of caregivers experienced pain and grief to a large extent as they dealt with the death of one or often multiple children and grandchildren. Over $85 \%$ of caregivers experienced signs of grief and reported feeling very alone since the passing of their child. Almost $85 \%$ had difficulties sleeping, $80.8 \%$ were unable to accept the fact that their child passed away and $81.3 \%$ believed the death of their child to be unfair.

Table 3.4 provides an overview of the means, standard deviations and inter-correlations of the psychosocial measures. Also socio-demographic variables such as number of dependents, number of people with HIV and AIDS in the household, available support and number of caregiving tasks were included as they were expected to have an impact on perceived grief. The respondents experienced a relatively high level of grief with a mean score of 3.94 (range $1-5$ ). Grief correlated significantly in different strengths with the other variables and ranged from a weak -.07 for the total number of dependents to a strong .48 for perceived stigma related to HIV and AIDS. Variables which showed a strong and positive correlation with grief were stigma related to HIV and AIDS, passive and proactive coping skills, worries about care, subjective norms related to 


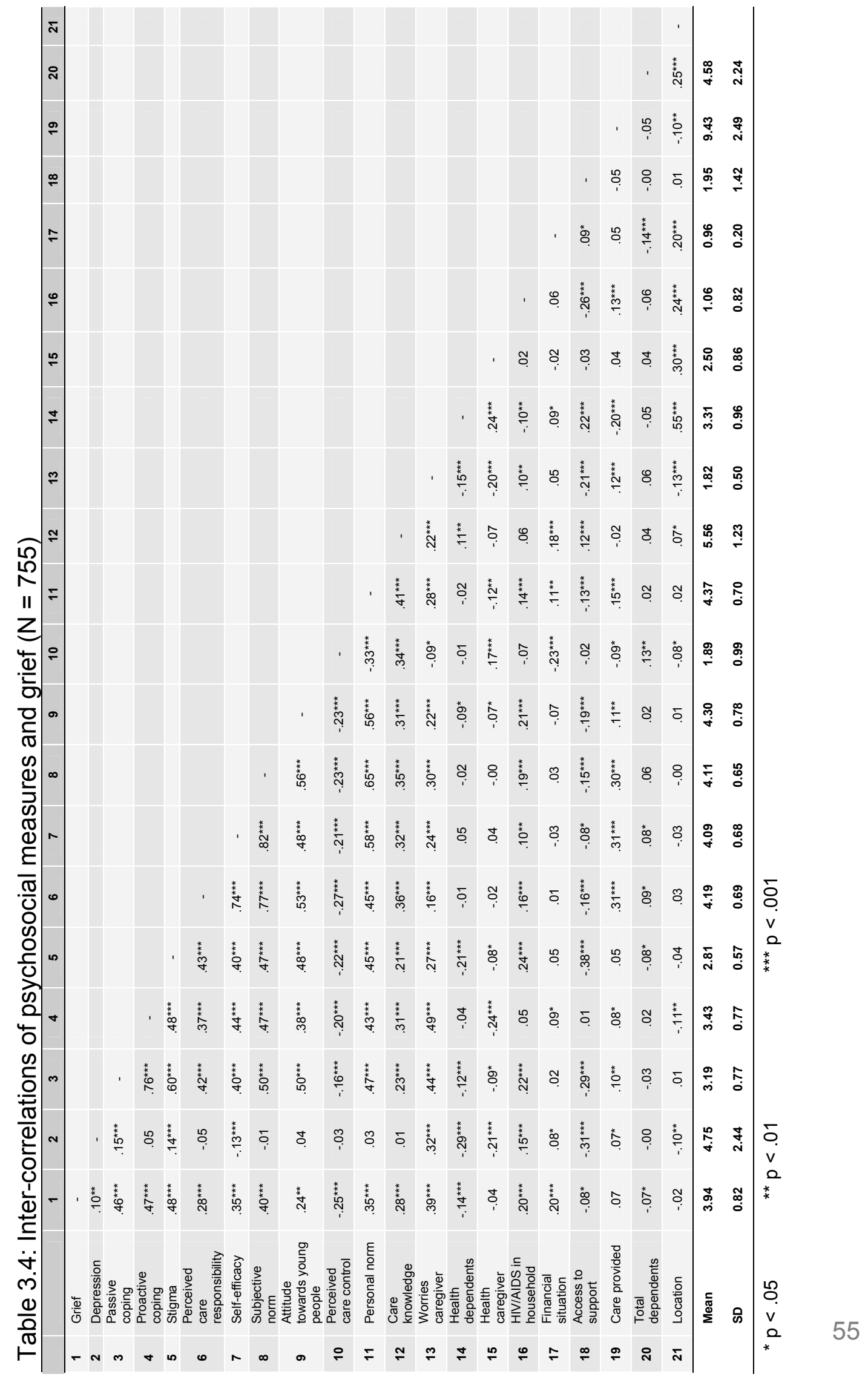


providing care, self-efficacy to provide care and personal norm towards providing care. Grief correlated less strongly, but positively with knowledge about care, a negative attitude towards young people, the number of people with HIV or AIDS in the household, experiencing financial problems and depression. Grief correlated strongly but negatively with perceived behaviour control to look after young people. Weaker negative correlations with grief were with the health status of the dependents, access to support services and the total number of dependents. Whether the caregiver lived in Motherwell or Uitenhage ('location') was not significantly correlated with grief.

Hierarchical multiple regression was used to explore relationships between significant univariate correlates of grief. Table 3.5 displays the standardised regression coefficients (betas) and $\mathrm{R}^{2}$ for each step. The final regression model was significant with $F(17,677)$ $=31.54, p<.001$. In the final model, forty-four percent of the variance in the concept grief could be explained by the significant univariate correlates $\left(\mathrm{R}^{2}=.44\right)$. A higher level of grief was associated with more stigma, more worries about providing care, more negative attitudes towards youths, more passive coping, more HIV and AIDS infections in the household, more financial problems, worse health conditions of dependents, less perceived responsibility to provide care, higher perceived subjective norms related to providing care and a lower level of perceived behavioural control to look after young people. A higher level of grief was also associated with more self-efficacy towards providing care, more knowledge on providing car and more access to support. The remaining significant univariate correlates (i.e., personal norm towards providing care, depression, total number of dependents and proactive coping skills) did not provide a significant unique contribution to the variance in grief.

Due to the inverted sign of the beta for perceived responsibility to provide care, the attitude towards young people and access to support services - compared with the univariate relationships of these variables with grief, the presence of possible suppressor variables was 
explored for these predictors. However, in-depth analyses that excluded congruent predictors (i.e., sign of correlation and beta are the same) one at the time showed that for each of the three predictors possible suppressor effects were not directly bound to one specific variable. ${ }^{1}$

Interactions with site were found for depression $(\beta=-.13 ; \mathrm{p}<$ $.001)$, perceived care responsibility $(\beta=-.07 ; \mathrm{p}<.05)$, subjective norm towards providing care $(\beta=-.07 ; \mathrm{p}<.05)$, personal norm towards providing care $(\beta=-.14 ; \mathrm{p}<.001)$ and access to support $(\beta=$ $.10 ; \mathrm{p}<.01)$. In Motherwell, depression was negatively associated with grief $(\beta=-.12 ; p<.01)$, whereas in Uitenhage the relation between depression and grief was positive $(\beta=.16 ; \mathrm{p}<.01)$. Perceived care responsibility was negatively associated with grief $(\beta=$ $-.15 ; p<.05)$ in Motherwell, and no significant association was found in Uitenhage. For subjective norm towards providing care, neither Motherwell nor Uitenhage showed significant associations with grief. Personal norm towards providing care was positively related with grief in Uitenhage $(\beta=.24 ; \mathrm{p}<.001)$, while in Motherwell no significant relation was found. Only in Motherwell, access to support showed to be positively associated with grief $(\beta=.12 ; \mathrm{p}<.01)$, while no significant interaction with Uitenhage was found.

\footnotetext{
${ }^{1}$ For perceived responsibility to provide care, self-efficacy and subjective norm were identified as possible suppressor variables of the effect of perceived responsibility on grief. For access to support, stigma and passive coping skills were identified as possible suppressors; whereas for attitude towards young people, possible suppressor variables were knowledge about care, perceived behavior control, number of people with HIV in the household, health of the dependents and access to support services. However, low to medium correlations of possible suppressor variables with their respective suppressed variables refutes the hypothesis that these variables were suppressors. Several independent variables may make the isolation of the suppressor difficult and reference is therefore made to suppressor situations rather than specific suppressor variables.
} 


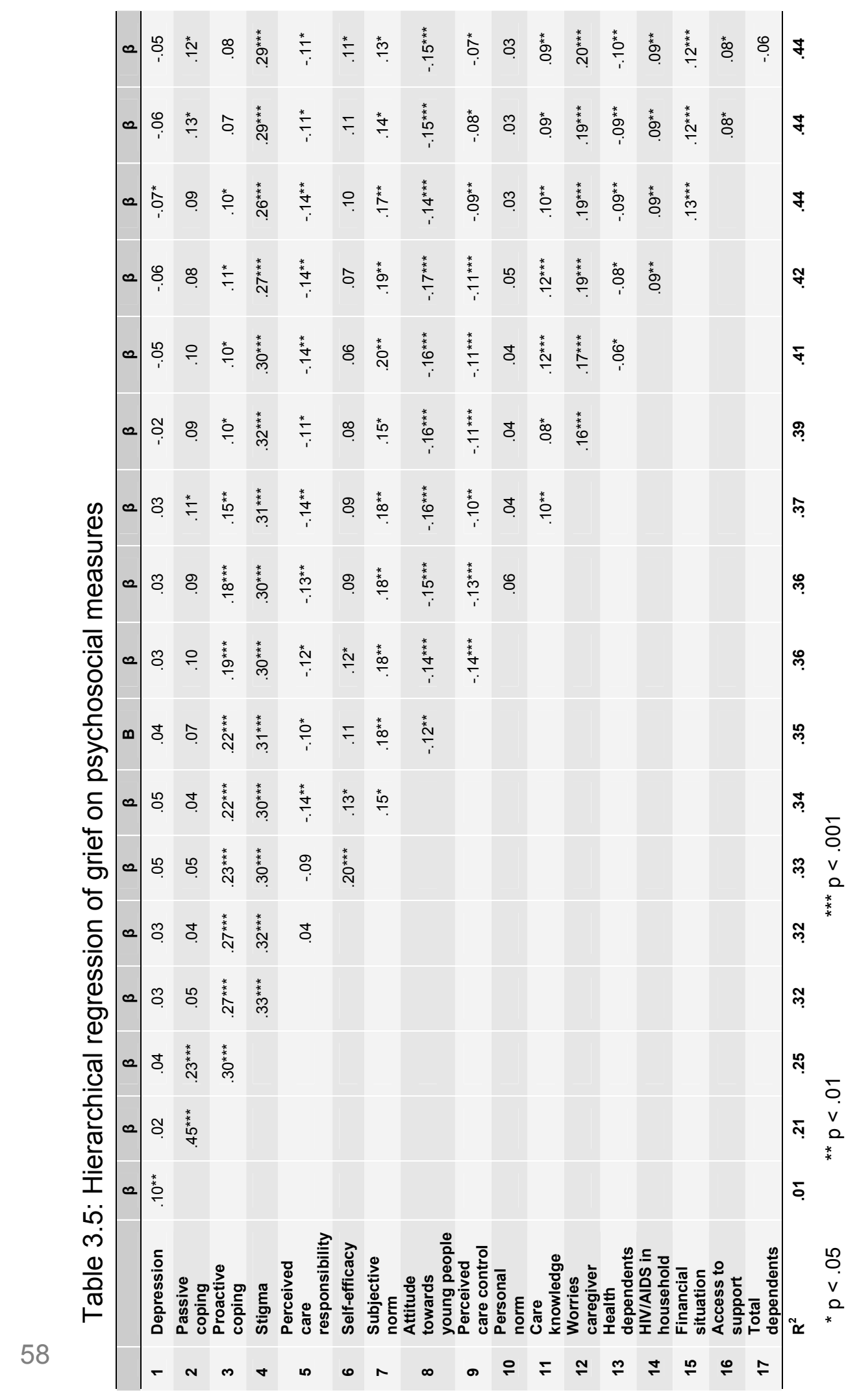




\section{Discussion}

This study has demonstrated that older caregivers in South Africa experience a substantial amount of grief due to the illness or passing away of their child(ren) and/or grandchild(ren) due to AIDS. The extent to which stigma relating to HIV and AIDS was perceived and experienced by them was the factor that was most strongly associated with grief. This was followed by their worries about providing care to their dependents. Moderate correlates of grief were negative attitudes towards youth, passive coping skills, more HIV and AIDS infections in the household, higher perceived subjective norms, more financial problems, less perceived responsibility towards providing care, worsening health conditions of dependents, and a lower level of perceived control over youth behaviour. Somewhat counterintuitive were the findings that a higher self-efficacy, more knowledge on providing care and more access to support services were associated with a higher level of grief. These results thus lend credence to grief of older persons being influenced by a wide range of psychosocial and environmental variables.

Findings from existing literature confirm that stigma from society is one of the major limiting factors of providing adequate care for people living with HIV or AIDS (Mwinituo \& Mill, 2006), as stigma exacerbates the emotional state of the person who is known to have HIV or AIDS (Appleton, 2000; Posel, Kahn, \& Walker, 2007; Thomas, 2006) as well as the emotional state of the caregiver (Ntozi, 1997b; Orner, 2006). As a consequence of stigma, fear and the experience of social isolation, shame, ridicule and loneliness may further increase levels of emotional stress and worry (Iwelunmor, Airhihenbuwa, Okoror, \& Belue, 2008). The need for the development and implementation of supportive community structures which assist older persons in their role as caregivers are of utmost importance and should be part of possible solutions in reducing stigma in the community. 
The strong association between grief and worries about providing care may well be explained by strong cultural and normative beliefs of older persons regarding their caring duties on the one hand and difficulty in coping with the complex care situation with sick dependents and low access to support for caring on the other hand. Although done out of love, providing care places considerable emotional, financial and physical demands on the caregivers and restricts them in their daily functioning. With limited resources and support older persons are not well equipped to engage in this extent of caregiving (Ndaba-Mbata \& Seloilwe, 2000; Nyambedha, Wandibba, \& Aagaard-Hanssen, 2003b; Ssengonzi, 2007) and emotional consequences such as stress, sadness tension and worries are inevitable.

A counterintuitive finding is that older people are more likely to experience grief as their self-efficacy to provide care increases. Those who were more confident in their tasks as caregiver, might also feel better able to allow themselves to grieve, as they may not see it as something negative, but as a part of life that has to be worked through. Working through has been defined as "a cognitive process of confronting a loss, of going over the events before and at the time of the death, of focussing on memories and working towards detachment from the deceased" (Stroebe, 1992). More knowledge on providing care seemed to increase feelings of grief, no possible explanation could be found for this. A similar finding was found for the availability of support as more support was shown to increase feelings of grief. When older people have access to more social support, they have more opportunities to share their emotions, and to cope with their loss. However, sharing emotions could be rather unpleasant and induce feelings of sadness and grief, as verbalising emotions does not necessarily reduce the emotional load and does not contribute to emotional recovery (Pennebaker, Zech, \& Rimé, 2001). This could provide a possible explanation for an increased level of expressed grief when having more support resources available and thus having 
more opportunities to share emotions. Furthermore a possible explanation could be that the support older people receive is not always provided by professionals but by family or community members, who might not know how to provide correct moral and psychological support in order for older people to reduce feelings of grief.

Differences between sites were found for depression, perceived responsibility to provide care, subjective norms towards providing care, personal norm towards providing care and access to support. Only in Uitenhage depression and personal norm towards providing care were positively associated with perceived feelings of grief. In Motherwell, depression and perceived responsibility towards providing care were negatively associated with grief, while access to support was positively related to grief. No possible explanations could be found to clarify and understand the differences in findings between sites, as demographically Motherwell and Uitenhage were highly comparable.

The results from this study can be used as a basis for the development of a tailored intervention which assists older people to deal with grief in the situation as caregiver. As stigma by the community was identified as the most important predictor of grief, it is important for future intervention programmes not only to focus on the individual but also on the social environment. Understanding the beliefs of HIV and AIDS in the community as well as the involvement of community members in the development of a programme is essential to enhance acceptance of the intervention by the target population and the community at large as well as for successful programme implementation. In the development of an intervention programme it is important to focus on variables that are changeable. Future interventions should therefore also include information on how to reduce worries and financial problems, besides skills for constructive coping with feelings of grief and care-giving need to be demonstrated as well. Simultaneously, supportive structures such as 
expansion of the South African pension system for older caregivers should be developed on governmental level.

Even though the results of this study complement and support existing research on the caring for children and grandchildren as a result of HIV and AIDS by older people, caution should be observed in generalising the results to other populations, as this study was tailored specifically to African older people in the Eastern Cape of South Africa. In addition, the differences in findings between demographically comparable sites emphasise that when applying the used scales in different settings and situations, it is important to always systematically define the relevant correlates to the specific context and population. This should be done by means of thorough preliminary research and testing of measurement instruments. The correlates that were found in this study could possibly be used as a starting point.

In conclusion, this study has improved our understanding of the psychosocial and environmental predictors of grief in older people who provide care for adult children and grandchildren as a result of HIV and AIDS. It provides useful information for further research and development of tailored intervention programmes and supportive structures to assist older people in their tasks as caregivers and to mitigate the effects of HIV and AIDS on older adults and those for whom they care. 


\section{Chapter 4}

Explaining perceived ability among older people to provide care as a result of HIV and AIDS in South Africa

\section{Based on:}

Boon, H., James, S., Ruiter, R.A.C., van den Borne, B., Williams, E., \& Reddy, P. (in press). Explaining perceived ability among older people to provide care as a result of HIV and AIDS in South Africa. AIDS Care. 


\section{Introduction}

In the past few years the HIV and AIDS epidemic has become one of the most important public health challenges in South Africa. A recent report by the Department of Health indicated that 5.4 million South Africans were infected with HIV with the rate of infection being highest amongst people between the ages of 15 and 49 years (Department of Health, 2007). As health services are unable to accommodate the increasing numbers of patients, the care of sick adult children and orphaned grandchildren is primarily left in the hands of elderly parents (Ntozi \& Nakayiwa, 1999; Williams \& Tumwekwase, 2001), mainly elderly women (Madhavan, 2004; Ssengonzi, 2009) who often have little or no support to assume responsibilities for the physical, emotional and economic needs of their dependents (Freeman \& Nkomo, 2006; Knodel, 2005; Ntozi \& Nakayiwa, 1999; Nyambedha, Wandibba, \& Aagaar-Hansen, 2003a; Schatz, 2007; Ssengonzi, 2007; Williams \& Tumwekwase, 2001).

In South Africa, the situation of grandparents caring for their adult and grandchildren is however not new. Its history of Apartheid and labour migration systematically divided African families by recruiting men and women to the centres for employment (Chazan, 2008; Madhavan, 2004; Marais, 2005). Families were in a reciprocal exchange while older people facilitated the economic migration of younger adults by caring for their grandchildren and safeguarding the family land and assets (Hosegood \& Timaeus, 2006). What is new to this situation is that AIDS has undermined the traditional reciprocal care arrangements as migrant parents fall ill and die, and therefore can no longer provide remittances to the grandparents caring for their children (Chazan, 2008; Madhavan, 2004; Marais, 2005). Besides, parents themselves may move back home to be nursed (Clark, Collinson, Kahn, Drullinger, \& Tollman, 2007; Marais, 2005; Schatz, 2007). As a result, older people have to endure the emotional, physical, financial and social costs that arise from their role as 
caregivers (e.g., Freeman \& Nkomo, 2006; Ntozi \& Nakayiwa, 1999; Nyambedha, Wandibba, \& Aagaar-Hansen, 2003a; Schatz, 2007; Ssengonzi, 2007).

To support older people in their role as caregivers, an understanding of their beliefs and needs with respect to providing care is required. Existing research has identified potential factors related to the care-giving roles of older caregivers (Freeman \& Nkomo, 2006; Ssengonzi, 2007; Ssengonzi, 2009; Williams \& Tumwekwase, 2001), but there is a lack of evidence regarding the relative contributions of these factors in explaining the perceived ability to provide care. This paper therefore aims to identify the psychological correlates of the perceived ability of older caregivers to provide different aspects of care which will impact on the development of targeted programmes to assist older caregivers. Further, the results of this case study in combination with results from other studies adds to a better understanding of the psychosocial context within which older caregivers provide HIV and AIDS related care.

\section{Method}

\section{Study Design}

This quantitative study consisted of a cross-sectional survey among 409 isiXhosa speaking elderly caregivers of 60 years and older, who reported caring for their sick adult children and/or grandchildren as a result of HIV and AIDS. The elderly caregivers were from Motherwell and Uitenhage, two districts in the Eastern Cape of South Africa.

\section{Study Setting}

Historically the Eastern Cape is home to a predominantly isiXhosa speaking population and portrays a culture rich in traditions. The study sites of Motherwell and Uitenhage consist of informal settlements and are part of the Nelson Mandela Metropolitan 
Municipality that has a population of just over 1 million people (Statistics South Africa, 2007). The majority of the population is African, younger than 30 years of age, do not have a secondary school qualification and live below the Household Subsistence Level poverty line on an annual income of R19200 (about 2313 USD) (Department of Provincial and Local Government South Africa, 2008; Nelson Mandela Bay Municipality, 2008).

As with many informal settlements in the Eastern Cape, Motherwell and Uitenhage are faced with high rates of unemployment, poverty and service delivery backlogs (Nelson Mandela Bay Municipality, 2008) and a high prevalence of HIV infection. In 2006, 29 percent of the antenatal clinic attendees were found to be HIV positive (Department of Health in South Africa, 2007). In the Nelson Mandela Metropolitan HIV and AIDS was most prevalent among the African population. The African population had the largest number of maternal $(81.2 \%)$ and paternal $(70.3 \%)$ orphans (Development Partners, 2007).

\section{Participants}

In total 200 participants from Uitenhage and 209 from Motherwell completed the survey. Eight participants did not fulfil the inclusion criteria and were removed from the analyses. The inclusion criteria were that participants spoke isiXhosa, were over the age of 60 and were looking after one or more children and/or grandchildren. The age of 60 was maintained as cut-off point as this is the pensionable age for women in South Africa. This resulted in a total sample of 401 elderly caregivers.

\section{Procedure}

As no detailed population statistics were available for the study sample from which a probability sample could be extracted, community health workers were approached to provide access to 
caregivers with whom they had worked with extensively. The community health workers were employed by Age-in-Action, a local non-governmental organisation and partner in this study.

Eighteen trained community health workers, nine from Motherwell and nine from Uitenhage, all first language isiXhosa speaking women were recruited onto the study. They were responsible for inviting the participants who received services from the Age-inAction club to participate in the study. Through a snow-ball effect some older persons in the community became aware of the study and showed their interest to participate. They were included if they matched the inclusion criteria.

The community health workers conducted one-on-one interviews with the participants. Questions and response options were read out to the participants and answers were recorded on paper questionnaires. The interviews were conducted in isiXhosa, the first language of both interviewers and participants. Each interview took about one hour and twenty minutes. Interviews took place at the homes of the participants where they usually receive the services provided by the Age-in-Action club. As the health workers were known to the participants and they usually visited them in their homes there was minimal concern that these visits would arouse suspicion or curiosity from neighbours and family.

Detailed information about the content, procedures and confidentiality of the study was provided to the participants both verbally and in writing in isiXhosa before consent was obtained. Ethical approval for the study was granted by the South African Medical Association Ethics Committee.

\section{Measurement Instrument}

The measurement instrument was based on existing literature about older people as providers of care, foregoing qualitative and quantitative research (Boon et al., under review; Boon et al., 2010a; Freeman \& Nkomo, 2006; Reddy, 2005; Nyambedha, Wandibba, \& 
Aagaard-Hansen, 2003a; Ssengonzi, 2007; Williams \& Tumwekwase, 2001), and general predictors of human behaviour derived from social cognition models (Connor \& Norman, 2005). Demographic questions concerning age, gender, relationship status, monthly income and number of dependents were included.

All psychological measures were based on Likert-type items with three or five response options. For each measure, scores on items that showed sufficient internal consistency (Cronbach's alpha $[\alpha]>$ .60) were averaged into one single index. Higher scores reflect a stronger presence of the concerning variable. Based on previous research (Boon et al., 2010a; Reddy, 2005), four care abilities were identified that served as outcome variables; (1) the perceived ability to provide nursing care; (2) the perceived ability to effectively communicate with children in different generations; (3) the perceived ability to provide an income for the household, and (4) the perceived ability to take time to relax. An overview of the psychological measures, including sample items and the Cronbach's alpha, is presented in Table 4.1. 


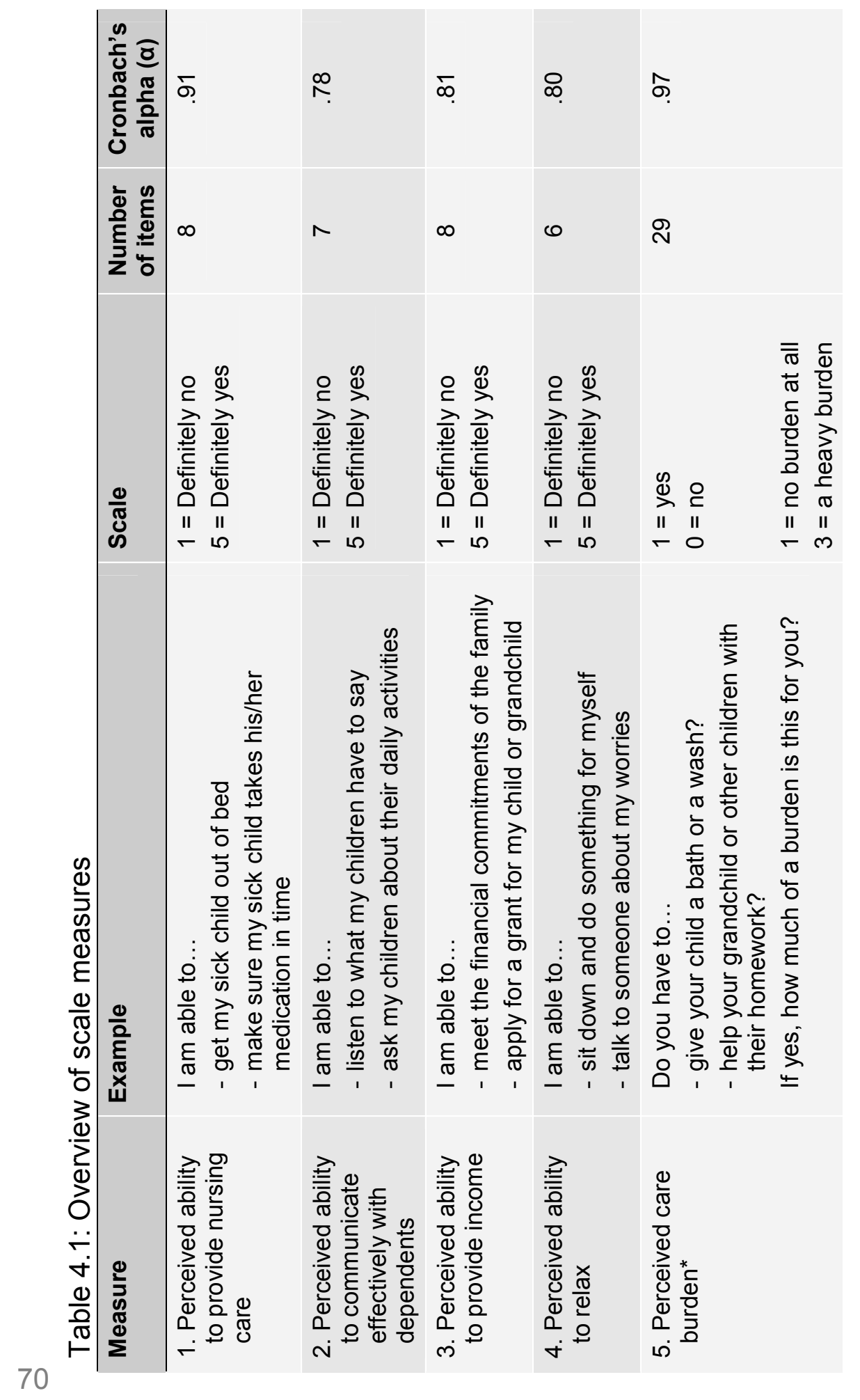




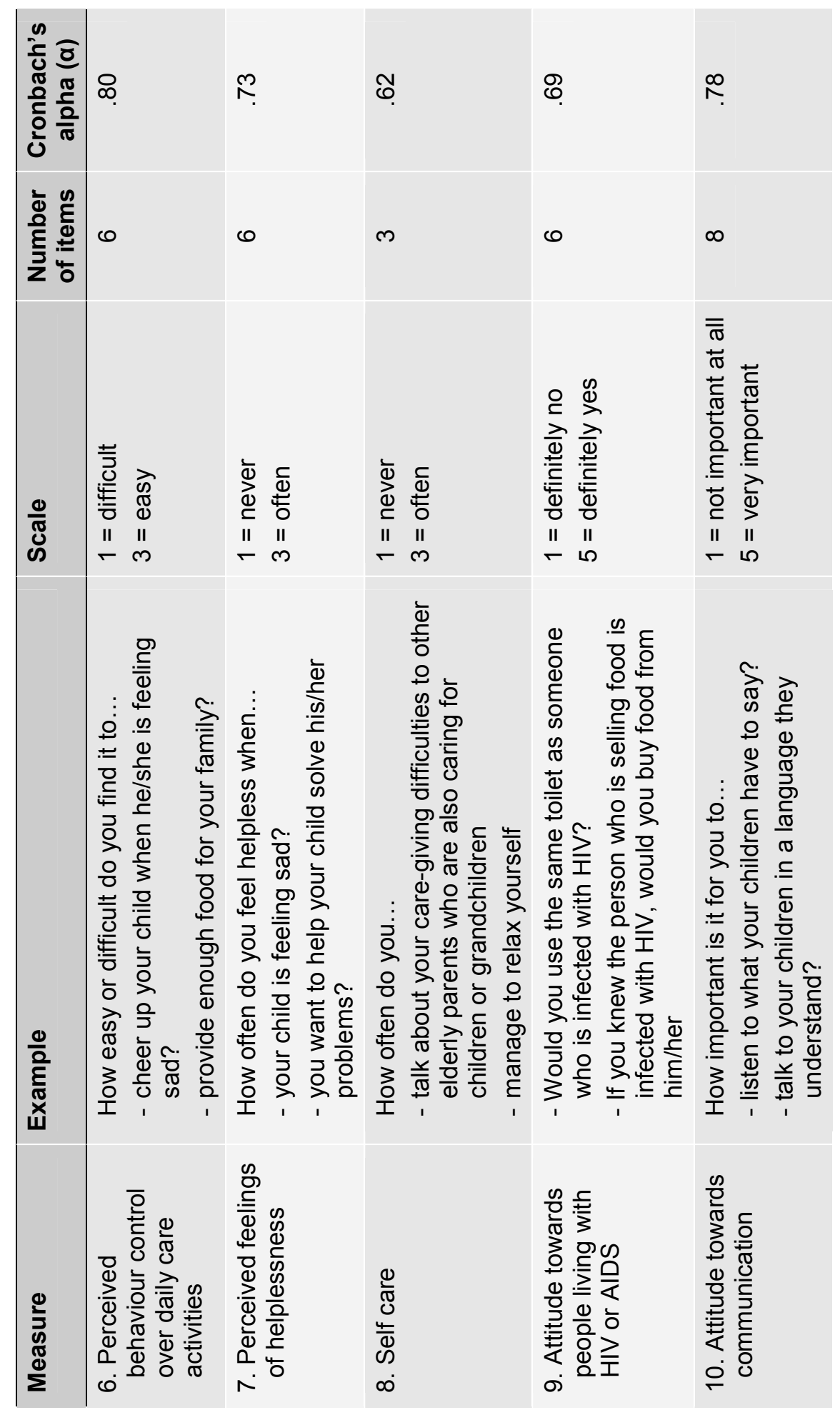




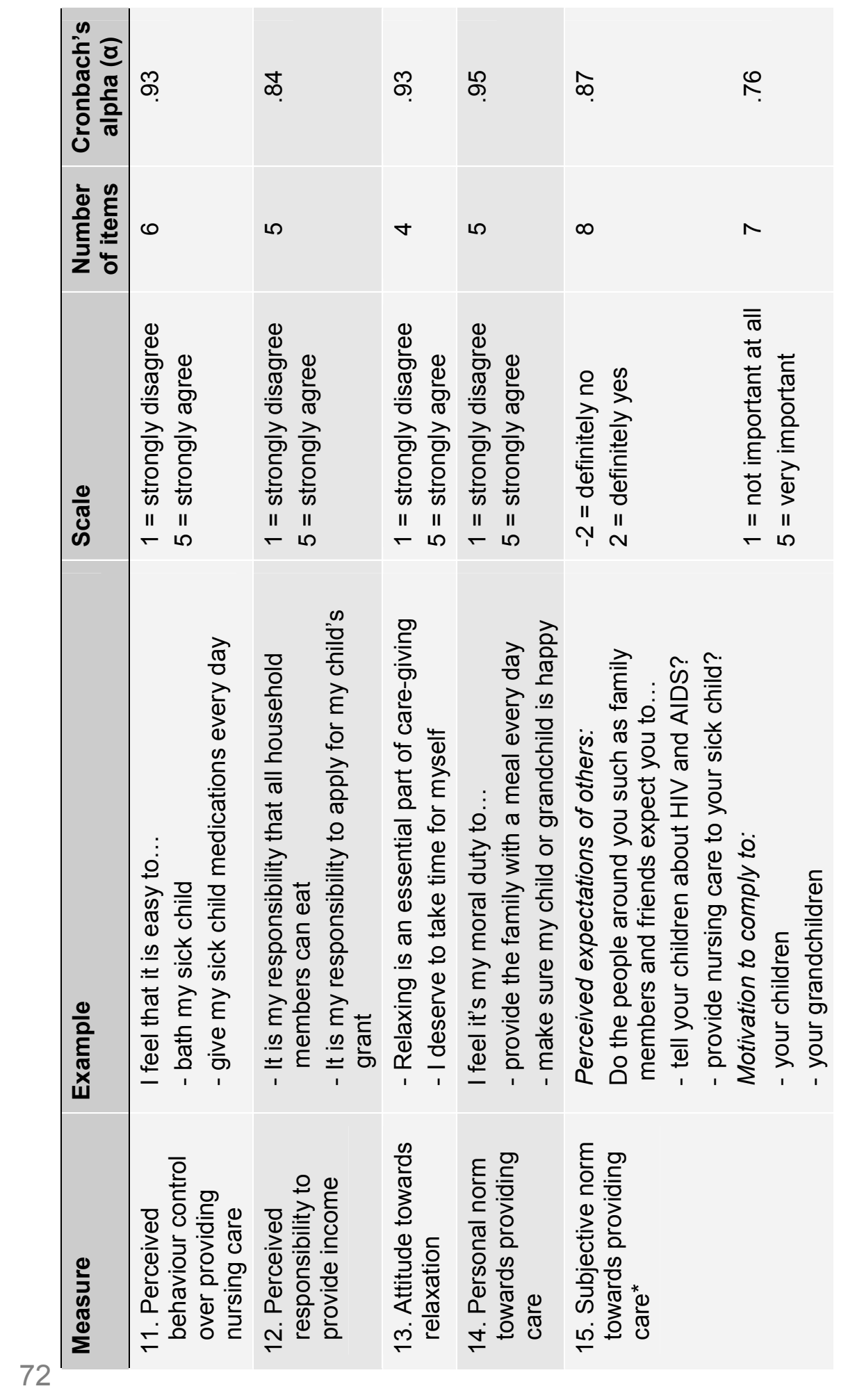




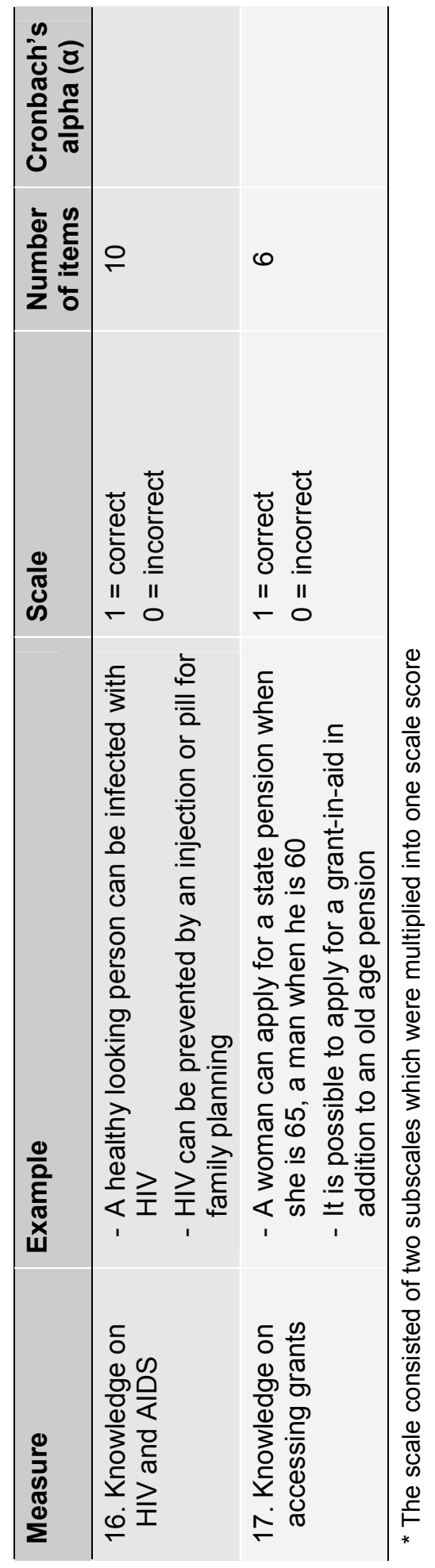




\section{Data analysis}

In the main analyses, bivariate correlations were calculated for the psychosocial variables. As eighteen interviewers were responsible for data collection, all participants were nested within a certain interviewer. To control for possible influences of the interviewer on the individual's responses, linear mixed model analyses were conducted to determine for each of the four dimension of perceived caring ability the unique contribution of significant $(\mathrm{p}<.05)$ univariate correlates, with interviewer included as random effect variable. Furthermore, to control for possible differences between the two study sites, significant correlate $\mathrm{x}$ site interactions were included in the mixed model analyses. Subsequently simple effect analyses were conducted to determine for each site the influence of the correlate on the specific dimension of perceived ability. A 5\% significance level was observed throughout.

\section{Results}

\section{Demographics}

Most of the participants were female $(\mathrm{N}=344 ; 85.8 \%)$, widowed $(\mathrm{N}=211 ; 52.6 \%)$ and between 60 and 69 years of age $(\mathrm{N}=$ $184 ; 45.9 \%)$. About half of the participants $(\mathrm{N}=199 ; 49.6 \%)$ went to school, of which $148(74.4 \%)$ completed only primary school. The majority of older persons $(\mathrm{N}=261 ; 65.1 \%)$ had to manage with a monthly income between 500 and 1000 South African Rand (approx. between 60 and 120 USD at the time of our research). For most participants $(\mathrm{N}=291 ; 72.6 \%)$, the old age government grant of 740 South African Rand per month (approx. 89 USD) was the main source of income. 


\section{Care-giving Details}

On average, elders cared for 4.65 children and grandchildren (range 1 - 16). In total, $118(29.4 \%)$ caregivers cared for only grandchildren and $11(2.7 \%)$ provided care for only adult children. The majority of $224(55.9 \%)$ caregivers cared for both grandchildren and adult children, and $46(11.4 \%)$ caregivers also cared for other dependents, such as grandchildren or adult children of relatives or neighbours.

\section{Correlates of perceived abilities related to providing care}

Means, standard deviations and inter-correlations of the study measures are shown in Table 4.2. On the outcome measures, the highest mean score was found for the perceived ability to communicate with children and grandchildren, followed by the ability to provide nursing care and the ability to relax. The lowest mean score was found for the older person's perceived ability to provide an income. 


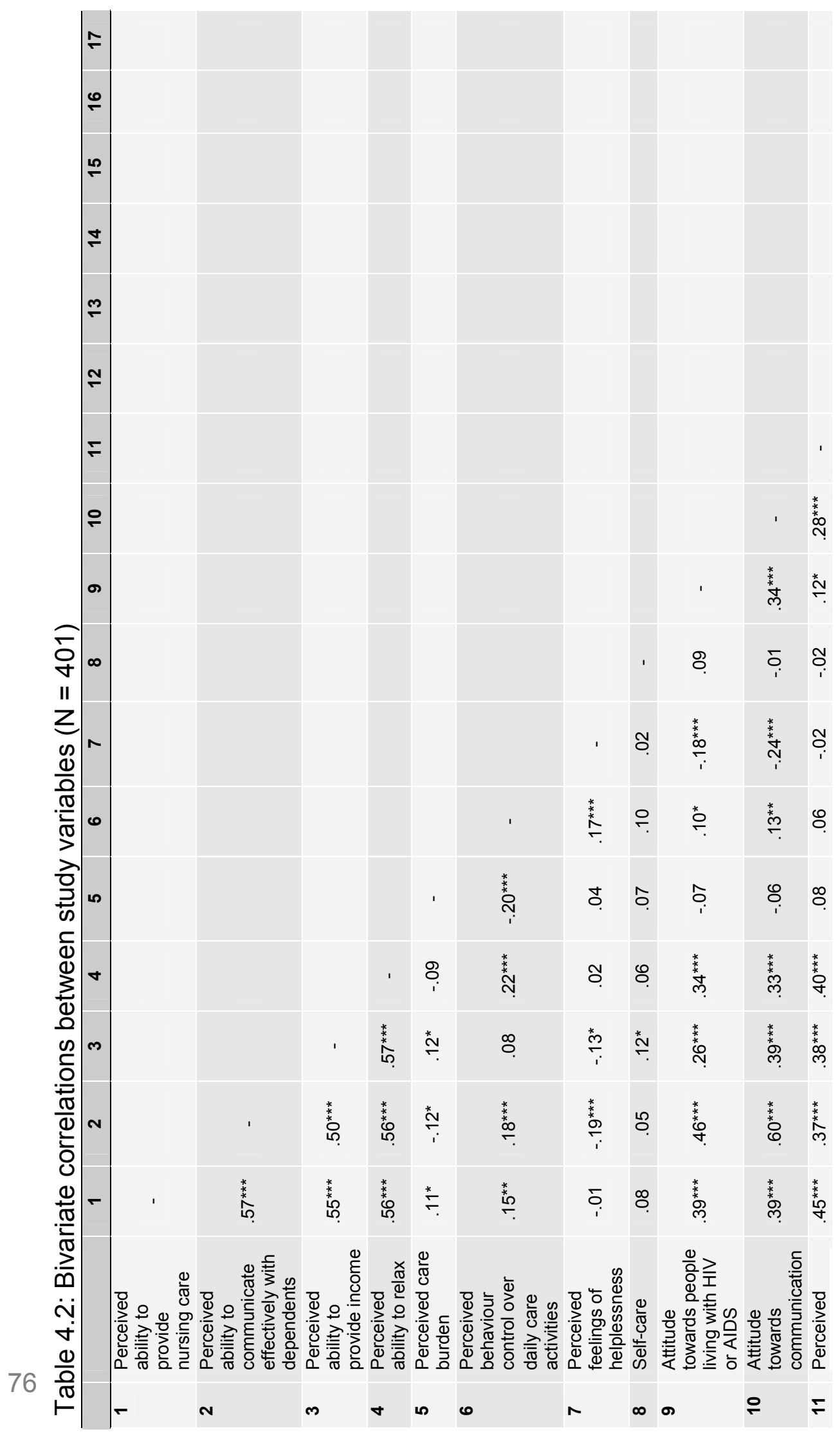




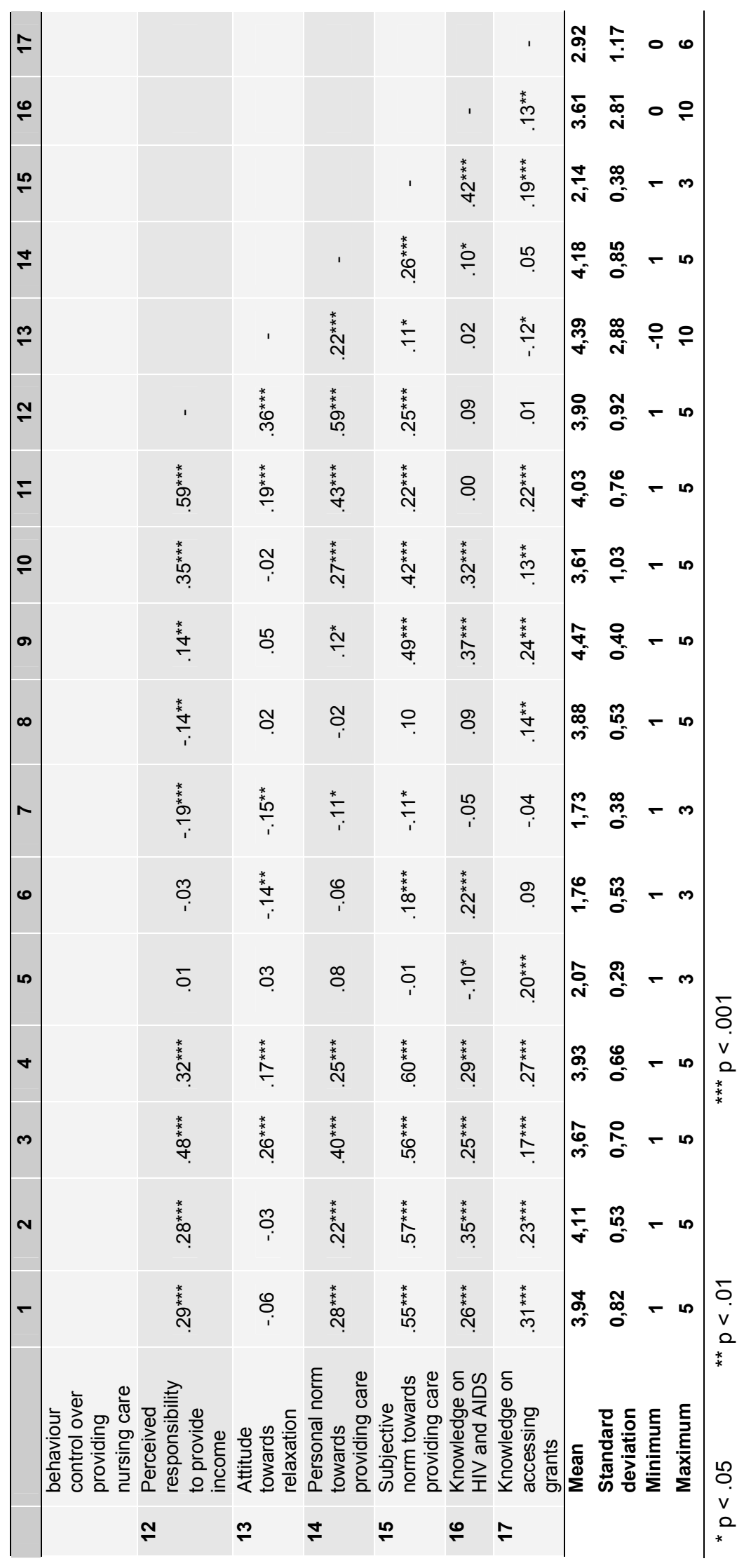


Table 4.3 displays the estimates of fixed effect $(\beta)$, standard error (SE), and explained variance (R2) for each dimension of perceived caring ability.

\section{Perceived ability to provide nursing care}

To explain the variance in providing nursing care, unique contributions were found for knowledge on accessing grants, personal norm towards providing care, attitude towards people living with HIV or AIDS, perceived care burden, and subjective norm towards providing care. Higher scores on these variables were related to more positive perceptions of the ability to provide nursing care. In addition, significant interactions between site of study and personal norm towards providing care, knowledge on accessing grants, and perceived behavioural control over providing nursing care were found respectively. Simple effect analyses showed that among those living in Uitenhage personal norm towards providing care $(\beta=.21 ; \mathrm{SE}=.04 ; \mathrm{p}$ $<.001)$ and knowledge on accessing grants $(\beta=.20 ; \mathrm{SE}=.04 ; \mathrm{p}<$ $.001)$ were positively associated with the ability to provide nursing care, whereas in Motherwell no significant associations were found for both concepts $(\beta=-.14 ; \mathrm{SE}=.08 ; \mathrm{p}>.05$ and $\beta=-.02 ; \mathrm{SE}=.04 ; \mathrm{p}$ $>.05$, respectively). Furthermore, the interaction pattern between site and perceived behaviour control over providing nursing care showed a positive relation to the perceived ability to provide care in Motherwell $(\beta=.17 ; \mathrm{SE}=.06 ; \mathrm{p}<.01)$, whereas in Uitenhage no significant relationship was found $(\beta=-.01 ; \mathrm{SE}=.06 ; \mathrm{p}>.05)$. The total model explained $41 \%$ of the total variance in perceived ability to provide nursing care.

\section{Perceived ability to communicate effectively with dependents}

The perceived ability to communicate with dependents was explained with unique contributions from attitude towards 
communication, attitude towards people living with HIV or AIDS, perceived behaviour control over providing nursing care, knowledge on accessing grants and subjective norm towards providing care. Higher scores on these variables were associated with higher scores in the outcome variable. Furthermore, the association between knowledge on accessing grants and perceived ability to communicate effectively with dependents differed for Motherwell and Uitenhage. In Uitenhage knowledge on accessing grants was found to be significantly correlated with the ability to communicate effectively with dependents $(\beta=.06 ; \mathrm{SE}=.02 ; \mathrm{p}<.01)$, whereas in Motherwell no significant association was found $(\beta=-.02 ; \mathrm{SE}=.02 ; \mathrm{p}>.05)$. The total model explained $49 \%$ of the variance in the perceived ability to effectively communicate with dependents.

\section{Perceived ability to provide income}

A higher perceived ability to provide income was associated with a more negative attitude towards people living with HIV or AIDS, a more positive attitude towards communication, a more positive personal norm towards providing care, a higher knowledge on accessing grants, and a more positive subjective norm towards providing care. Furthermore, interactions with site were found for perceived feelings of helplessness, attitude towards people living with HIV and AIDS, perceived responsibility to provide income, and knowledge on accessing grants. In Motherwell, perceived feelings of helplessness $(\beta=.29 ; \mathrm{SE}=.14, \mathrm{p}<.05)$, and perceived responsibility to provide income $(\beta=.23 ; \mathrm{SE}=.07, \mathrm{p}<.01)$ were positively associated with the perceived ability to provide income. In Uitenhage no significant associations were found for both concepts $(\beta=-.13$; SE $=.08 ; \mathrm{p}>.05$ and $\beta=.01 ; \mathrm{SE}=.05 ; \mathrm{p}>.05)$. In Uitenhage, attitude towards people living with HIV and AIDS was negatively related to perceived ability to provide income $(\beta=-.29 ; \mathrm{SE}=.06, \mathrm{p}<.001)$, which was not found in Motherwell $(\beta=.09$; $\mathrm{SE}=.09 ; \mathrm{p}>.05)$. 
Finally, in Motherwell, knowledge about accessing grants was negatively associated with perceived ability to provide income $(\beta=-$ $.08 ; \mathrm{SE}=.03, \mathrm{p}<.05)$, while in Uitenhage the association was positive $(\beta=.06 ; \mathrm{SE}=.03, \mathrm{p}<.05)$. Forty-one percent of the variance in perceived ability to provide income could be explained by the correlates in the model.

\section{Perceived ability to relax}

Attitude towards communication, perceived responsibility to provide income, perceived behaviour control over providing nursing care, attitude towards relaxation, subjective norm towards providing care, and knowledge on accessing grants uniquely contributed to the prediction of perceived ability to relax. In addition, interaction effects were found between site and, respectively, attitude towards communication, perceived responsibility to provide income, perceived behaviour control over providing nursing care, and knowledge on accessing grants. In both Motherwell $(\beta=.12 ; \mathrm{SE}=.09, \mathrm{p}>.05)$ and Uitenhage $(\beta=-.20 ; \mathrm{SE}=.10, \mathrm{p}>.05)$, attitude towards communication was not significantly related to perceived ability to relax. In Uitenhage, both perceived behaviour control over providing nursing care $(\beta=.16 ; \mathrm{SE}=.05, \mathrm{p}<.001)$ and knowledge on accessing grants $(\beta=.15 ; \mathrm{SE}=.03, \mathrm{p}<.001)$ were positively associated with perceived ability to relax; whereas attitude towards providing income was negatively related to perceived ability to relax $(\beta=-.22 ; \mathrm{SE}=.07$, $\mathrm{p}<.001)$. In Motherwell, no significant associations were found between perceived behaviour control over providing nursing care $(\beta=$ $.00 ; \mathrm{SE}=.04, \mathrm{p}>.05)$, knowledge on accessing grants $(\beta=.03 ; \mathrm{SE}=$ $.03, \mathrm{p}>.05)$, attitude towards providing income $(\beta=.05 ; \mathrm{SE}=.06, \mathrm{p}$ $>.05$ ) and perceived ability to relax. The total model accounted for $37 \%$ of the variance in perceived ability to relax. 


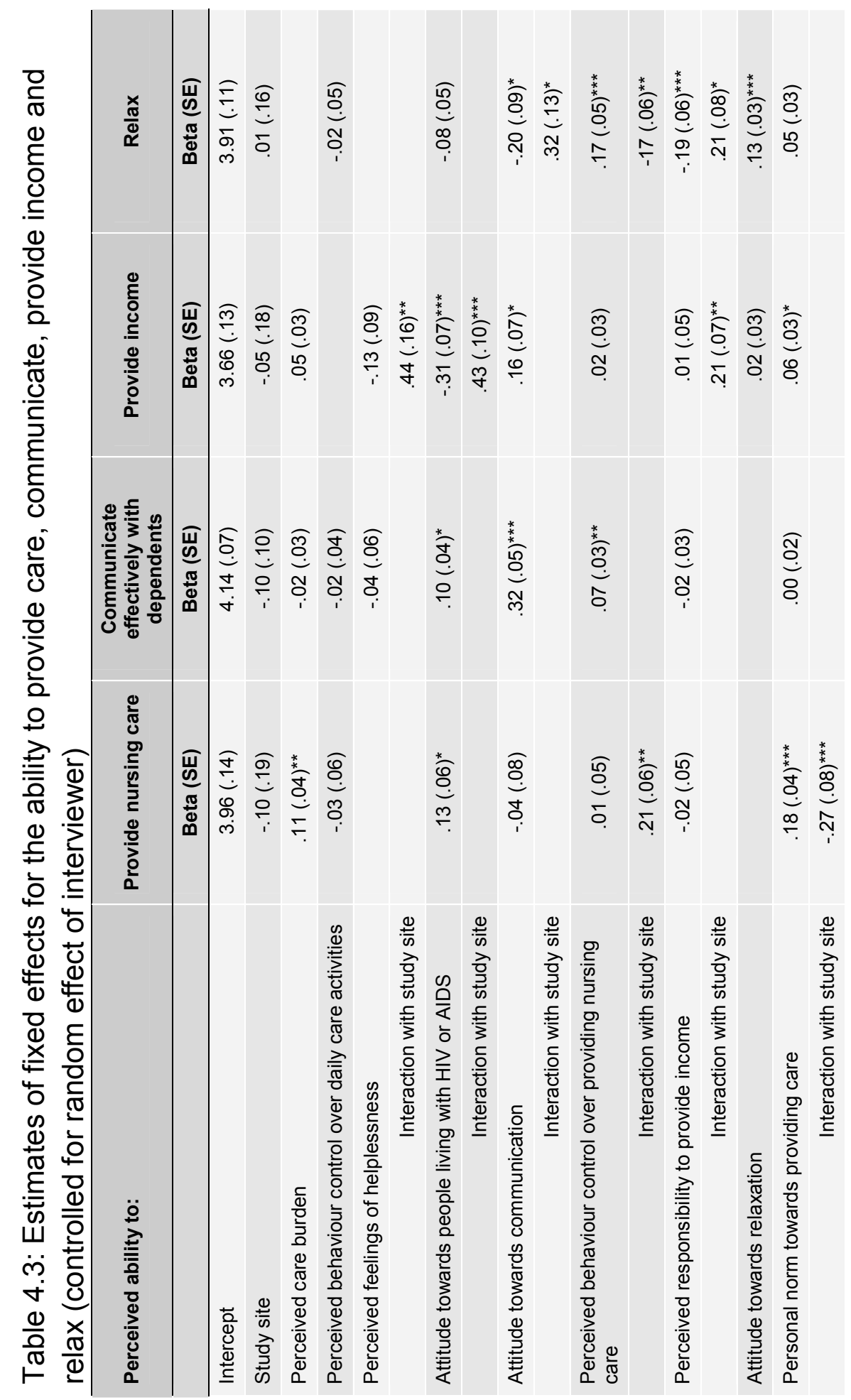




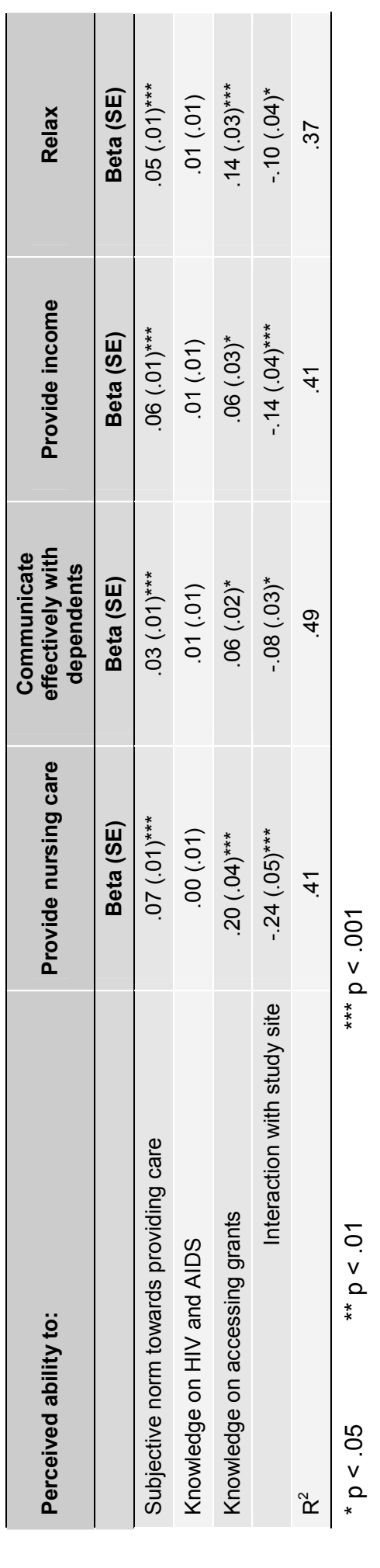




\section{Discussion}

In the present study, theoretical psychosocial constructs such as attitudes, perceived behaviour control over providing nursing care, personal and subjective norms towards providing care and knowledge on accessing grants were important predictors across the four ability dimensions. In addition, different correlates emerged for the different dimensions of caring ability that were explored. The most important predictors of caregivers' perceived ability to provide nursing care were more knowledge on accessing grants and a more positive personal norm towards providing care. Perceived ability to communicate effectively with children and grandchildren was predicted most strongly by a more positive attitude towards communication. A more negative attitude towards people living with HIV or AIDS and a more positive attitude towards communication were the primary predictors for perceived ability to provide income. Only in Motherwell feelings of helplessness were positively associated with perceived ability to provide income. The main predictors of perceived ability to relax were a more negative attitude towards communication, lower perceived responsibility to provide income and a higher perceived behaviour control over providing nursing care.

Somewhat counterintuitive was the finding that a more negative attitude towards people living with HIV or AIDS contributed to a higher perceived ability to provide income. This finding could possibly be explained by the impact that interpersonal or environmental variables have on the ability to provide income. Factors such as for example a bad relationship between the sick person and the caregiver, the reason why the older person took on the care-giving role (Nyambedha, Wandibba, \& Aagaard-Hansen, 2003a) or fear of disclosure and stigma from the community (Moore, 2008; Mwinituo $\&$ Mill, 2006) could have possibly contributed to a more negative attitude towards people living with HIV or AIDS. However these 
factors might not be restricting an older person's ability to provide income, especially when support from family or community members (Orner, 2006) is available. A negative attitude towards people living with HIV and AIDS could on the other hand also lead to social exclusion of the person infected with HIV as well as the family caregiver (Mwinituo \& Mill, 2006), resulting in less support from the community. The counterintuitive finding that a more negative attitude towards communication and a more negative attitude towards providing income contributed to higher perceived ability to relax could possibly be explained by older people not perceiving themselves responsible to provide income and to communicate effectively with children and grandchildren and therefore allow themselves time to relax.

Overall, by determining the relative importance of social cognitive constructs in understanding care-giving related behaviours these findings add relevant information to existing research that mostly used qualitative study designs to determine the needs, consequences and challenges of older caregivers (e.g. Boon et al., under review; Schatz \& Ogunmefun, 2007; Ssengonzi, 2007, 2009; Williams \& Tumwekwase, 2001). Nevertheless one should be cautious in generalising the findings to other populations as this study was conducted among a convenience sample of older people in the Eastern Cape of South Africa. More case studies are needed to confirm our findings and extend the current knowledge base of psychosocial correlates of the ability to provide home care in the context of HIV and AIDS. Furthermore, the differences in findings we found between demographically comparable sites emphasise the importance of a detailed needs assessment and analysis of important predictors of outcome variables for every new study context. In addition to differences between sites, differences might also be found within sites among subpopulations, for example when comparing grandparents caring for only grandchildren versus grandparents caring for both adult and grandchildren. 
To conclude, this study has improved the understanding of the most important variables impacting on the care-giving ability of older people in the context of HIV and AIDS. By providing a core list of possible intervention targets (e.g. attitudes, personal norms towards providing care, perceived behaviour control over providing nursing control and knowledge on accessing grants) it provides valuable information for the systematic design and evaluation of educational interventions to assist older people in coping with their care-giving concerns. 


\section{Chapter 5}

\section{The impact of a community-based pilot health education intervention for older people as caregivers of orphaned and sick children as a result of HIV and AIDS in South Africa}

\section{Based on:}

Boon, H., Ruiter, R.A.C., James, S., van den Borne, B., Williams, E., \& Reddy, P. (2010). The impact of a communitybased pilot health education intervention for older people as caregivers of orphaned and sick children as a result of HIV and AIDS in South Africa. Journal of Cross-Cultural Gerontology, 24, 373-389. 


\section{Introduction}

In South Africa over the past few decades, the HIV and AIDS epidemic has placed a substantial burden on the older generation. Older people are left behind with the care for adult children with chronic illnesses or symptomatic HIV infection and grandchildren orphaned and made vulnerable by the death or illness of one or both of their parents. As health services are often unable to accommodate the increasing number of patients, families are faced with the task to take care of their sick family members at home (Ndaba-Mbata \& Seloilwe, 2000). The emphasis on community and home-based care as a strategy for meeting the care and support needs of those infected and affected by HIV and AIDS has impact on the psychosocial and physical wellbeing of older caregivers and on the care they provide. Previous research in South Africa has shown that older people live in extended family situations with their children, grandchildren and sometimes other dependents with an average of no less than 4.58 dependents per caregiver (Boon et al., 2010a). Adult children are mostly unemployed, sick or have passed away, leaving the full care and responsibility for grandchildren in the hands of the older generation. With little or no support, older caregivers endure emotional, physical, financial and social costs that arise from their tasks (Boon et al., 2010a, under review; Freeman \& Nkomo, 2006; HelpAge International, 2003; Ntozi \& Nakayiwa, 1999; Nyambedha, Wandibba, \& Aagaar-Hansen, 2003a; Reddy, 2005; Schatz, 2007; Ssengonzi, 2007). They assume both productive and child-raising responsibilities, for example by assisting grandchildren with their homework, nursing sick adult children and providing the family with financial means (Boon et al., 2010b; Chazan, 2008; Marais, 2005). Monthly pension grants that older people depend on are often insufficient to cover the basic needs of the entire household and older people often lack the correct documents and skills to apply for grants for their children or grandchildren (Boon et al., under review). Even though difficulties in providing care are encountered, older people care for their children 
and grandchildren willingly and mention love and responsibility as the main motives for taking on the caregiver role (Freeman \& Nkomo, 2006; Boon et al., under review; Orner, 2006).

Caregivers perceive a lack of skills to provide basic care for dependents (Kipp, Tindyebwa, Karamagi, \& Rubaale, 2007a; Olenja, 1999; Ssengonzi, 2007) while research indicates that family care giving is obstructed by the lack of training for family caregivers (Ndaba-Mbata \& Seloilwe, 2000). Also external factors such as poverty and the number of dependent children play a role in the quality of support they are able to provide (Madhavan, 2004; Ssengonzi, 2007). Available support for the community often comes from resources outside the family structure and includes communitybased programs (Madhavan, 2004) or financial assistance from the government (Department of Social Development, 2003; Schatz \& Ogunmefun, 2007).

Previous research (Boon et al., 2010b) has been conducted to identify the predictors of older people's perceived abilities to provide care, communicate with children and grandchildren, provide income, and being able to relax. That study showed that attitudes towards people living with HIV and AIDS, attitudes towards intergenerational communication with children and grandchildren, personal and subjective norms towards providing care, knowledge about accessing grants, and perceived control over nursing care activities were significant correlates of older people's perceived ability to handle their care-giving responsibilities. In addition, empowerment strategies to enable older people to develop their own skills and abilities to cope effectively with issues confronting them, has been proven an effective strategy for strengthening older people's interactions with their dependents (Cox, 2002). Based on this information, intervention programs should include methods and strategies to address above mentioned determinants in order to assist older people in building their capacity to take care for their dependents. 
In the present paper we describe the effectiveness of a pilot intervention program which aimed to address the determinants of the perceived ability among older people to provide care for sick children and vulnerable grandchildren (Boon et al., 2010b), by using suitable strategies such as verbal persuasion and practical skills development. The objectives of the intervention program were to (1) build capacity among older caregivers to provide reasonable care to sick and orphaned children and grandchildren, (2) enhance the ability of older caregivers to cope with their psychosocial needs, (3) facilitate intergenerational communication between older caregivers and their dependents, including on HIV and AIDS prevention issues, and (4) facilitate the dissemination of information to older people on existing community and social support services. It was hypothesized that participation in the four modules of this health education intervention would result in more knowledge on topics associated with HIV and AIDS and a higher perceived ability to take care of sick adult children and grandchildren.

\section{Methods}

\section{Study Design}

The effectiveness of the pilot intervention was tested in a longitudinal one-group study with a pretest at the start of the program, a post-test immediately after the program, and follow-up test three months after end of program. The study was conducted in Motherwell, a township in the city of Port Elizabeth in the Eastern Cape province of South Africa. ${ }^{2}$ Preliminary data analyses showed that not all

\footnotetext{
${ }^{2}$ Initially the study design comprised of a quasi-experimental controlled trial with a convenience sample of older caregivers in Motherwell as experimental group and a similar sample in Uitenhage as control group. In Motherwell older caregivers were to receive the intervention program, whereas in Uitenhage caregivers were encouraged to continue their usual Age-in-Action activities. In the course of the data analysis, however, basic baseline analyses showed significant differences
} 
caregivers from Motherwell completed all modules. We therefore decided to base the evaluation of the intervention not only on an analyses of baseline vs. post-test differences but also included a comparison between older caregivers in Motherwell who completed the full intervention by participating in all four sessions $(\mathrm{N}=141)$ and those who did not or only partly $(\mathrm{N}=63)$ in what can be called a quasi-experimental design.

\section{Study Setting}

The participants in this study were isiXhosa speaking people of 60 years and older who were responsible for the care for their sick children and/or (orphaned) grandchildren as a result of HIV and AIDS. Historically the Eastern Cape is home to a predominantly isiXhosa population and portrays rich cultural traditions. Motherwell consists of informal settlements and is part of the Nelson Mandela Metropolitan Municipality (NMMM). The majority of the population in the metropolitan is African, younger than 30 years old and does not have a secondary school qualification (Nelson Mandela Bay Municipality, 2008).

As other informal settlements in the Eastern Cape, Motherwell is faced with high rates of unemployment, poverty and service delivery backlogs (Department of Provincial and Local Government South Africa, 2005; Eastern Cape Department of Social Development,

\footnotetext{
between the two sites. This could have been corrected for in further analyses, however also interactions between baseline measures and study site were found, indicating that the impact of the baseline measures on the post-intervention measures was different for both study conditions. Also, in Uitenhage data was collected by the same community health workers at all three time points, and therefore could have influenced the validity of the data. In Motherwell data was only collected by community health workers at baseline, and new community members were trained for the collection of post-test and follow-up data who were further blind to the contents of the workshop sessions, increasing the validity of the data collection. Therefore it was decided to exclude the data collected in Uitenhage from the study.
} 
2008; Eastern Cape Provincial Government, 2008). According to the latest statistics of the Department of Health in South Africa (2007), HIV-infection and AIDS are very prevalent in the Eastern Cape as $28.6 \%$ of the antenatal clinic attendees in the Eastern Cape were found to be infected with HIV in 2006. No other specific information about the HIV prevalence in Motherwell was found.

\section{Participants}

In total 209 older persons participated in the baseline interview. Five participants were excluded from the data analyses as they did not fulfill the inclusion criteria, which were: participants had to speak isiXhosa, be over the age of 60 , and look after sick or orphaned children or grandchildren. Two participants were excluded as no consent forms were found for them. This resulted in a final sample of 202 participants.

\section{Recruitment and research procedures}

Six trained community health workers who were employed by Age-in-Action, a local non-governmental organization and partner in this project, and three community members, who were recruited by Age-in-Action were involved in recruiting participants, conducting the workshops, and collecting data. All recruiters were female, spoke isiXhosa as their first language and lived in the same community as the older caregivers. Through their extensive knowledge of the area and experience of working with older people through Age-in-Action, the health workers were able to access older caregivers in the community.

The recruiters approached isiXhosa speaking older caregivers of 60 years and older at their Age-in-Action club activities; they explained the aims and objectives of the study and invited them to participate. Through a snow-ball effect, other older community members became aware of the study and showed interest to 
participate. They were also approached by community health workers and were invited to participate if they matched the inclusion criteria.

Community health workers and community members received a four-day interactive training about the implementation of the intervention. They were taught in a participatory manner how to facilitate the workshops with the older people and on how to record the sessions. Four teams were set up comprising each of one facilitator and one co-facilitator. The training sessions as well as the actual modules were conducted in isiXhosa, the first language of both the health workers and the participants. Quality control was observed by an external professional who supported the health workers on-site and was able to immediately remedy situations that arose, especially by providing on-going motivation for the health workers to maintain the desired standard of training. Besides, the external professional person was also valuable in providing emotional support and counseling for participants who were in need of sharing their experiences.

The baseline data collection, using one-on-one interviews, was conducted by the six community health workers and three community members who were also trained to conduct the workshops. Post-test and follow-up data were collected by nine members of the community who were employed and trained merely for data collection except for three community members who were also involved in conducting the workshops. Questions and possible responses were read out loud to the participants and paper questionnaires were used to register responses. The interviews were conducted in isiXhosa and took place at the homes of the participants. Each interview took about one hour and twenty minutes. Detailed information about the content, procedures and confidentiality of the study was provided to the participants both verbally and in writing before consent was obtained. Ethical approval for the study was granted by the South African Medical Association Ethics Committee. 


\section{The Intervention}

Based on information collected in previous formative research (Boon et al., under review; Reddy, 2005), a quantitative survey (Boon et al., 2010a), a focus group discussion with community health workers of Age-in-Action and interviews with senior staff of Age-inAction, possible topics for the workshops were decided upon. Also relevant parts of existing manuals and interventions that were conducted in similar settings were adjusted, and contributed to the development of the intervention (Nurses Association of Botswana, 2004; Saleh-Onoya et al., 2008; Save the Children, 2003; Sifunda, 2006; Vlok, 1977; Willis, McGilvray, McNally, \& Pawinski, 2005;). The workshops were based on interactive, participatory discussions and practical exercises. Factual knowledge was provided through talks and handouts. The groups consisted of 10 to 12 older participants each. The intervention consisted of four weekly workshop-sessions, each of about three hours containing a range of topics. Module 1 provided accurate information about HIV and AIDS and explored the behavior and understanding of young people of today. Module 2 addressed skills to bridge the generational communication gap between caregivers and their children and grandchildren and included topics such as how to talk about sensitive matters. Module 3 focused on skills to provide basic home-based nursing care to sick children and aimed at improving knowledge to maintain medication compliance. Module 4 explored the topic of social assistance and provided up-to date information on accessing the available support services. Besides, each workshop included a component in which practical relaxation techniques and basic exercises were trained. A more detailed overview of the content of the modules can be found in Appendix A. 


\section{Workshop Participation}

Caregivers were invited to participate in all four workshops. Of the 202 participants, 141 older people completed all four workshop sessions, 13 participants did not attend all four workshops and 48 participants did not attend any workshop session at all. Reasons for non-attendance were mostly related to health problems $(\mathrm{N}=22)$, being out of town $(\mathrm{N}=9)$ or work responsibilities $(\mathrm{N}=3)$. Two participants were not able to attend due to death in their families, one participant was not fully aware of the transport arrangements for attending the workshops and one participant was unable to leave her sick child alone. Two participants passed away during the course of the study and one participant was not interested in attending the workshops. For seven participants the reasons for non-attendance were unknown. All participants were provided daily with transport, tea and lunch and on completion of the training they received a gift as a token of appreciation. After completion of the workshops, an immediate post-test interview was conducted among 177 participants (response rate $=88 \%$ ), followed by a follow-up interview after three months among 182 participants (response rate $=90 \%$ ).

\section{Measures}

The measurement instruments were based on findings from previous qualitative and quantitative studies (Boon et al., under review; Boon et al., 2010a; Reddy, 2005), existing literature about older people as providers of care, and general predictors of human behavior derived from social cognition models (Connor \& Norman, 2005). Demographic details included age, gender, marital status, schooling, income and number of dependents.

An overview of the measurements at baseline, immediate posttest and follow-up, including scales, examples of items and Cronbach's alpha can be found in Table 5.1. All measurements were based on Likert-type items with three, four or five response options. 
Validated instruments were used to measure depression (i.e., Hopkins Symptom Checklist-25; Derogatis, Lipman, Richels, Uhlenhuth, \& Covi, 1974; Hesbacher, Rickels, Morris, Newman, \& Rosenfeld, 1980) and ways of coping (i.e., Ways of Coping Checklist; Folkman $\&$ Lazarus, 1985). Factor analysis was used to confirm the structures of existing scales and subscales. For the depression scale, all items, except two which were culturally inappropriate, were included into one scale after inspection of the scree-plot, which showed one factor. The original Ways of Coping Checklist (Folkman \& Lazarus, 1985) defined six subscales. In this study, factor analysis did not find the expected six subscales. After thorough inspection of the individual items and the scree-plot, the scale was divided into two subscales: proactive and passive coping (see Table 5.1). One item was removed from the passive coping scale as it was not appropriate in the cultural context of the sample.

For each measure, scores on items that showed sufficient internal consistency (Cronbach's alpha $[\alpha]>.60$ ) were averaged into a single index. Higher scores reflected a stronger presence of the concerning variable. 
Table 5.1: Overview of scale measures at baseline, post-test and follow-up ${ }^{3}$

\begin{tabular}{|c|c|c|c|c|}
\hline Measure & Example & Scale & $\begin{array}{l}\text { Num- } \\
\text { ber of } \\
\text { items }\end{array}$ & $\begin{array}{l}\text { Cronbach } \\
\text { 's alpha } \\
\text { (a) }\end{array}$ \\
\hline $\begin{array}{l}1 \text { Ability to } \\
\text { provide } \\
\text { nursing care }\end{array}$ & $\begin{array}{l}\text { I am able to... } \\
\text { - get my sick child } \\
\text { out of bed }\end{array}$ & $\begin{array}{l}1=\text { Definitely no } \\
5=\text { Definitely yes }\end{array}$ & 8 & .82 \\
\hline $\begin{array}{l}2 \text { Ability to } \\
\text { communicate } \\
\text { with children } \\
\text { and } \\
\text { grandchildren }\end{array}$ & $\begin{array}{l}\text { I am able to... } \\
\text { - listen to what my } \\
\text { children have to say }\end{array}$ & $\begin{array}{l}1=\text { Definitely no } \\
5=\text { Definitely yes }\end{array}$ & 7 & .61 \\
\hline $\begin{array}{l}3 \text { Ability to } \\
\text { provide income }\end{array}$ & $\begin{array}{l}\text { I am able to... } \\
\text { - apply for a grant for } \\
\text { my child or } \\
\text { grandchild }\end{array}$ & $\begin{array}{l}1=\text { Definitely no } \\
5=\text { Definitely yes }\end{array}$ & 8 & .80 \\
\hline 4 Ability to relax & $\begin{array}{l}\text { I am able to... } \\
\text { - talk to someone } \\
\text { about my worries }\end{array}$ & $\begin{array}{l}1=\text { Definitely no } \\
5=\text { Definitely yes }\end{array}$ & 5 & .66 \\
\hline $\begin{array}{l}5 \text { Perceived } \\
\text { burden of care }\end{array}$ & $\begin{array}{l}\text { How much of a } \\
\text { burden is it for you } \\
\text { when you have to... } \\
\text { - give your child a } \\
\text { bath or a wash? }\end{array}$ & $\begin{array}{l}1=\text { no burden at } \\
\text { all } \\
3=\text { a heavy } \\
\text { burden }\end{array}$ & 29 & .99 \\
\hline 6 Depression & $\begin{array}{l}\text { How often in the past } \\
\text { week did you... } \\
\text { - feel low in energy? }\end{array}$ & $\begin{array}{l}1=\text { never } \\
3=\text { often }\end{array}$ & 13 & .73 \\
\hline
\end{tabular}

${ }^{3}$ The values are derived from the baseline data. 


\begin{tabular}{|c|c|c|c|c|}
\hline Measure & Example & Scale & $\begin{array}{l}\text { Num- } \\
\text { ber of } \\
\text { items }\end{array}$ & $\begin{array}{l}\text { Cronbach } \\
\text { 's alpha } \\
\text { (a) }\end{array}$ \\
\hline 7 Coping* & $\begin{array}{l}\text { Proactive coping: } \\
\text { In dealing with your } \\
\text { problems, how often } \\
\text { in the past } 3 \text { months } \\
\text { have you... } \\
\text { - talked to someone } \\
\text { about your } \\
\text { feelings? } \\
\text { Passive coping: } \\
\text { In dealing with your } \\
\text { problems, how often } \\
\text { in the past } 3 \text { months } \\
\text { have you... } \\
\text { - tried to keep your } \\
\text { feelings to yourself? }\end{array}$ & $\begin{array}{l}1=\text { not at all } \\
4=\text { most of the } \\
\text { time }\end{array}$ & 8 & .88 \\
\hline $\begin{array}{l}8 \text { Perceived } \\
\text { behavior } \\
\text { control over } \\
\text { daily care } \\
\text { activities }\end{array}$ & $\begin{array}{l}\text { How easy or difficult } \\
\text { do you find it to... } \\
\text { - cheer up your child } \\
\text { when he/she is } \\
\text { feeling sad? }\end{array}$ & $\begin{array}{l}1=\text { difficult } \\
3=\text { easy }\end{array}$ & 6 & .72 \\
\hline $\begin{array}{l}9 \text { Feelings of } \\
\text { helplessness }\end{array}$ & $\begin{array}{l}\text { How often do you } \\
\text { feel helpless when... } \\
\text { - your child is feeling } \\
\text { sad? }\end{array}$ & $\begin{array}{l}1=\text { never } \\
3=\text { often }\end{array}$ & 4 & .70 \\
\hline $\begin{array}{l}10 \text { Attitude } \\
\text { towards people } \\
\text { living with HIV } \\
\text { or AIDS }\end{array}$ & $\begin{array}{l}\text { - Would you use the } \\
\text { same toilet as } \\
\text { someone who is } \\
\text { infected with HIV? }\end{array}$ & $\begin{array}{l}1=\text { definitely no } \\
5=\text { definitely yes }\end{array}$ & 3 & .59 \\
\hline $\begin{array}{l}11 \text { Attitude } \\
\text { towards } \\
\text { communication } \\
\text { with children } \\
\text { and } \\
\text { grandchildren }\end{array}$ & $\begin{array}{l}\text { How important is it } \\
\text { for you to... } \\
\text { - listen to what your } \\
\text { children have to } \\
\text { say? }\end{array}$ & $\begin{array}{l}1=\text { not important } \\
\text { at all } \\
5=\text { very important }\end{array}$ & 8 & .63 \\
\hline $\begin{array}{l}12 \text { Perceived } \\
\text { behavior } \\
\text { control over } \\
\text { providing } \\
\text { nursing care }\end{array}$ & $\begin{array}{l}\text { I feel that it is easy } \\
\text { to... } \\
\text { - bath my sick child }\end{array}$ & $\begin{array}{l}1 \text { = strongly } \\
\text { disagree } \\
5=\text { strongly agree }\end{array}$ & 6 & .83 \\
\hline
\end{tabular}




\begin{tabular}{|c|c|c|c|c|}
\hline Measure & Example & Scale & $\begin{array}{l}\text { Num- } \\
\text { ber of } \\
\text { items }\end{array}$ & $\begin{array}{l}\text { Cronbach } \\
\text { 's alpha } \\
\text { (a) }\end{array}$ \\
\hline $\begin{array}{l}13 \text { Perceived } \\
\text { responsibility } \\
\text { towards } \\
\text { providing an } \\
\text { income }\end{array}$ & $\begin{array}{l}\text { - It is my } \\
\text { responsibility that } \\
\text { all household } \\
\text { members can eat }\end{array}$ & $\begin{array}{l}1 \text { = strongly } \\
\text { disagree } \\
5=\text { strongly agree }\end{array}$ & 5 & .72 \\
\hline $\begin{array}{l}14 \text { Attitude } \\
\text { towards } \\
\text { relaxation }\end{array}$ & $\begin{array}{l}\text { - I deserve to take } \\
\text { time for myself }\end{array}$ & $\begin{array}{l}1 \text { = strongly } \\
\text { disagree } \\
5=\text { strongly agree }\end{array}$ & 4 & .78 \\
\hline \multirow[t]{2}{*}{$\begin{array}{l}15 \text { Subjective } \\
\text { norm }^{* *}\end{array}$} & $\begin{array}{l}\text { Perceived } \\
\text { expectations of } \\
\text { others: } \\
\text { Do the people } \\
\text { around you such as } \\
\text { family members and } \\
\text { friends expect you } \\
\text { to... } \\
\text { - provide nursing } \\
\text { care to your sick } \\
\text { child? }\end{array}$ & $\begin{array}{l}-2=\text { definitely no } \\
2=\text { definitely yes }\end{array}$ & 8 & .77 \\
\hline & $\begin{array}{l}\text { Motivation to comply } \\
\text { to: } \\
\text { - your children }\end{array}$ & $\begin{array}{l}1=\text { not important } \\
\text { at all } \\
5=\text { very important }\end{array}$ & 7 & .69 \\
\hline $\begin{array}{l}16 \text { Personal } \\
\text { norm }\end{array}$ & $\begin{array}{l}\text { I feel it's my moral } \\
\text { duty to... } \\
\text { - make sure my child } \\
\text { or grandchild is } \\
\text { happy }\end{array}$ & $\begin{array}{l}1 \text { = strongly } \\
\text { disagree } \\
5=\text { strongly agree }\end{array}$ & 5 & .85 \\
\hline $\begin{array}{l}17 \text { Knowledge } \\
\text { on HIV and } \\
\text { AIDS }\end{array}$ & $\begin{array}{l}\text { - A healthy looking } \\
\text { person can be } \\
\text { infected with HIV }\end{array}$ & $\begin{array}{l}1=\text { correct } \\
0=\text { incorrect }\end{array}$ & 10 & \\
\hline $\begin{array}{l}18 \text { Knowledge } \\
\text { on accessing } \\
\text { grants }\end{array}$ & $\begin{array}{l}\text { - A woman can apply } \\
\text { for a state pension } \\
\text { when she is } 65, \text { a } \\
\text { man when he is } 60\end{array}$ & $\begin{array}{l}1=\text { correct } \\
0=\text { incorrect }\end{array}$ & 6 & \\
\hline
\end{tabular}

* Two subscales were derived after factor analysis: proactive and passive coping

** The scale consisted of two subscales which were multiplied into one scale score 


\section{Data analyses}

SPSS v15.0 (SPSS, Chicago, IL) was used to analyze the data. The analysis was stratified by baseline, post-test and follow-up. During the study, analyses showed that not all participants completed all workshops, and therefore a comparison could be made between participants with complete participation $(\mathrm{N}=141)$ and participants with incomplete or no participation $(\mathrm{N}=61)$. Frequency analyses were conducted to describe the demographic characteristics of the study sample at baseline and Pearson's Chi Square $\left(\chi^{2}\right)$ and t tests to determine possible statistically significant differences between the participating and non-participating groups. Paired-samples t tests were conducted to test the differences between baseline and post-test and between baseline and follow-up for the total sample. Separate univariate analyses of covariance (ANCOVA) were conducted to explore the effects of the intervention at immediate post-test and 3month follow-up respectively for those with complete participation vs. those with incomplete or no participation, while controlling for baseline measures. A 5\% significance level was observed throughout.

\section{Results}

\section{Demographics and Care-giving Details}

Most of the participants were female, between the ages of 60 and 69 and widowed. Forty-seven participants were married. A minority of the sample attended formal schooling and completed primary school. Half of the caregivers indicated that they did not receive an income at all and for those that did receive an income, it was a monthly household income of less than R1000 (approx. 120 USD at the time of the study). A small pension grant of R740 per month was the main source of income for the majority of participants. Three-quarter of the caregivers indicated to be solely responsible for their children and/or grandchildren and on average, participants cared 
for 4.97 dependents with the range being 1 to 15 . No demographic differences were found between participants who completed all workshops and participants who did not. See Table 5.2 for an overview.

Table 5.2: Demographic and care-giving details of the study population $(\mathrm{N}=202)$

\begin{tabular}{l|c}
\hline Demographic information & $\begin{array}{c}\text { Number of participants } \\
(\%)\end{array}$ \\
\hline Gender & $165(81.7 \%)$ \\
Female & $34(16.8 \%)$ \\
Male & $3(1.5 \%)$ \\
Missing & \\
\hline Age & $79(39.1 \%)$ \\
Between 60 and 69 years & $73(36.1 \%)$ \\
Between 70 and 79 years & $47(23.3 \%)$ \\
Older than 80 years & $3(1.5 \%)$ \\
\hline Missing & \\
\hline Marital status & $47(23.3 \%)$ \\
\hline Married & $24(11.9 \%)$ \\
Single & $14(6.9 \%)$ \\
Divorced & $115(56.9 \%)$ \\
Widowed & $2(1.0 \%)$ \\
\hline Missing & \\
\hline Formal schooling & $80(39.6 \%)$ \\
\hline Attended & $118(58.4 \%)$ \\
\hline Did not attend & $4(2.0 \%)$ \\
\hline Missing & \\
\hline Highest school level complete & $34(16.8 \%)$ \\
Lower primary school & $31(15.3 \%)$ \\
\hline Higher primary school & $15(7.4 \%)$ \\
\hline Junior secondary school & $5(2.5 \%)$ \\
Senior secondary school & $117(57.9 \%)$ \\
\hline Missing &
\end{tabular}




\section{Demographic information}

Monthly income

No income

Less than R500

Between R500 and R1000

More than R1000

Missing

Main source of income

Pension grant

Unemployment benefits

Disability grant

Child support grant

Paid job

Care-giving situation

Number of dependents (M, SD)

Sole responsibility for dependents
Number of participants

(\%)

$101(50.0 \%)$

$4(2.0 \%)$

$80(39.6 \%)$

$4(2.0 \%)$

$13(6.4 \%)$

$103(51.0 \%)$

$3(1.5 \%)$

$2(1.0 \%)$

$17(8.4 \%)$

$1(0.5 \%)$

\section{Impact of the workshops at immediate post-test}

$151(74.8 \%)$

Table 5.3 provides an overview of the effectiveness of the workshops on the dependent variables at immediate post-test (T1) and at follow-up (T2). For the total sample, differences between baseline and post-test were found for 12 outcome variables. After the intervention at immediate post-test, all participants reported having a higher perceived ability to relax $(\mathrm{t}=-2.14 ; \mathrm{p}<.05)$, lower levels of depression $(\mathrm{t}=4.00 ; \mathrm{p}<.001)$, less passive coping skills $(\mathrm{t}=4.66 ; \mathrm{p}<$ $.001)$, less feelings of helplessness $(\mathrm{t}=2.22 ; \mathrm{p}<.05)$, more control over daily activities $(\mathrm{t}=-5.23 ; \mathrm{p}<.001)$, a more positive attitude towards people living with HIV or AIDS $(\mathrm{t}=-6.87 ; \mathrm{p}<.001)$, and more knowledge about HIV and AIDS $(t=-9.77$; $<<.001)$. At posttest participants also showed a lower perceived ability to provide income $(\mathrm{t}=4.88 ; \mathrm{p}<.001)$, less proactive coping skills $(\mathrm{t}=2.22 ; \mathrm{p}<$ $.05)$, less perceived responsibility to provide income $(\mathrm{t}=4.08 ; \mathrm{p}<$ 
$.001)$, a lower personal norm towards providing care $(\mathrm{t}=3.97$; $\mathrm{p}<$ $.001)$, and less knowledge about accessing grants $(\mathrm{t}=4.76 ; \mathrm{p}<.001)$.

Comparisons between participants who completed all workshops and those who completed only a few or no workshops showed that at immediate post-test participants who participated in all four workshops perceived themselves more able to provide nursing care than those who did not attend all workshops, $F(1,161)=19.03 ; p$ $<.001$. An effect was also found for participants' ability to relax, F (1, $167)=4.62 ; p<.05$, showing a higher perceived ability to relax among people who attended all workshops. Furthermore, participants who took part in the complete series of workshops were more likely to have a more positive attitude towards people living with HIV or AIDS, $F(1,167)=17.12 ; p<.001$; showed a higher subjective norm on providing care, indicating that they perceived the opinion of relevant others as more important, $\mathrm{F}(1,165)=26.48 ; \mathrm{p}<.001$; perceived more control over nursing care activities, $\mathrm{F}(1,167)=9.17$; $\mathrm{p}<.01$; and were more likely to improve their knowledge about HIV and AIDS issues, $\mathrm{F}(1,157)=38.29 ; \mathrm{p}<.001$.

\section{Impact of the workshops at 3-months follow-up}

For the total sample, several changes in outcome variables were maintained at the three-month follow-up. Compared to baseline, participants still showed a higher perceived ability to relax $(\mathrm{t}=-3.77$; $\mathrm{p}<.001)$ and also showed less depression $(\mathrm{t}=2.64 ; \mathrm{p}<.05)$. In contrast to the post-test where participants showed less proactive coping skills compared to baseline, at follow-up participants showed more proactive coping skills $(\mathrm{t}=-3.01 ; \mathrm{p}<.01)$. Participants also maintained less feelings of helplessness at follow-up $(\mathrm{t}=2.30 ; \mathrm{p}<$ $.05)$, and a higher perceived control over daily activities $(\mathrm{t}=-5.62 ; \mathrm{p}<$ $.001)$, in addition attitudes towards people living with HIV or AIDS were still more positive $(\mathrm{t}=-6.40 ; \mathrm{p}<.001)$, and the attitude towards relaxation was more positive $(\mathrm{t}=-1.99 ; \mathrm{p}<.05)$, also knowledge of HIV and AIDS remained higher $(\mathrm{t}=-10.06 ; \mathrm{p}<.001)$. Perceived 
ability to provide income remained lower after three months of follow-up $(\mathrm{t}=3.36 ; \mathrm{p}<.001)$, also perceived nursing control showed to be lower $(\mathrm{t}=3.82 ; \mathrm{p}<.001)$, as well as the perceived responsibility towards providing income $(\mathrm{t}=5.26 ; \mathrm{p}<.001)$. Personal norm towards providing care and knowledge of accessing grants was also lower at follow-up, i.e. $(\mathrm{t}=3.46 ; \mathrm{p}<.001)$ and $(\mathrm{t}=5.07 ; \mathrm{p}<.001)$ respectively.

When comparing participants with complete and incomplete participation at follow-up, participants who attended all workshops were still more likely to perceive themselves able to provide care for their dependents, $\mathrm{F}(1,172)=10.83 ; \mathrm{p}<.001$, compared to those who did not fully participate. Also a higher perceived ability to relax was found again for participants who attended all workshop sessions F (1, $176)=6.05 ; \mathrm{p}<.05$. Participants who were present at all workshops were also more likely to have a more positive attitude towards people living with HIV or AIDS, F $(1,177)=13.51 ; p<.001$, and showed more proactive coping skills $F(1,178)=4.26 ; p<.05$. Subjective norms towards providing care was still higher for caregivers who attended all sessions than for those who did not fully attend or not at all, $\mathrm{F}(1,172)=5.52 ; \mathrm{p}<.05$. As was found in the post-test, also in the follow-up knowledge about HIV and AIDS was higher among caregivers who completed all sessions $\mathrm{F}=(1,166)=34.37 ; \mathrm{p}<.001$. 


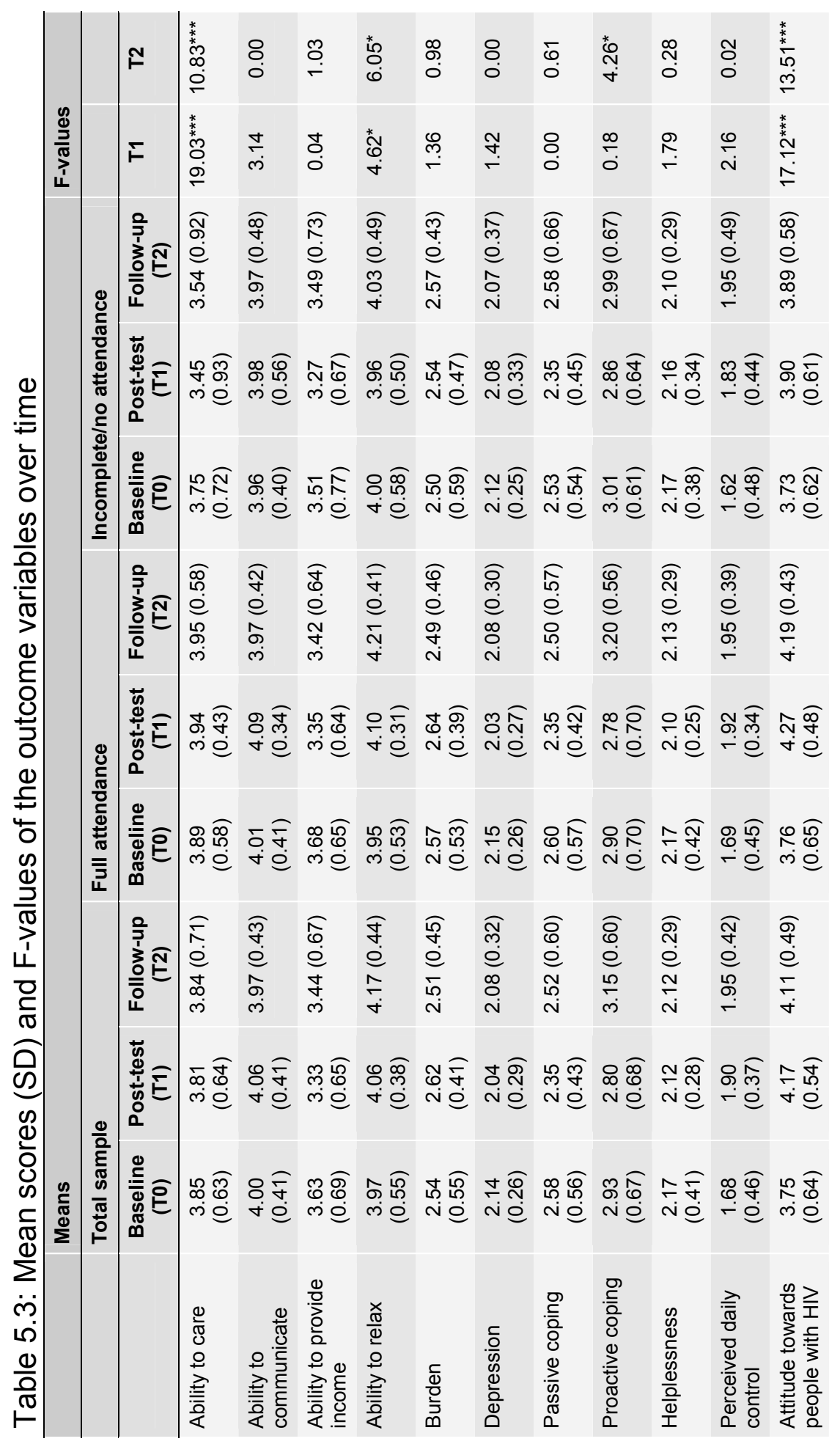




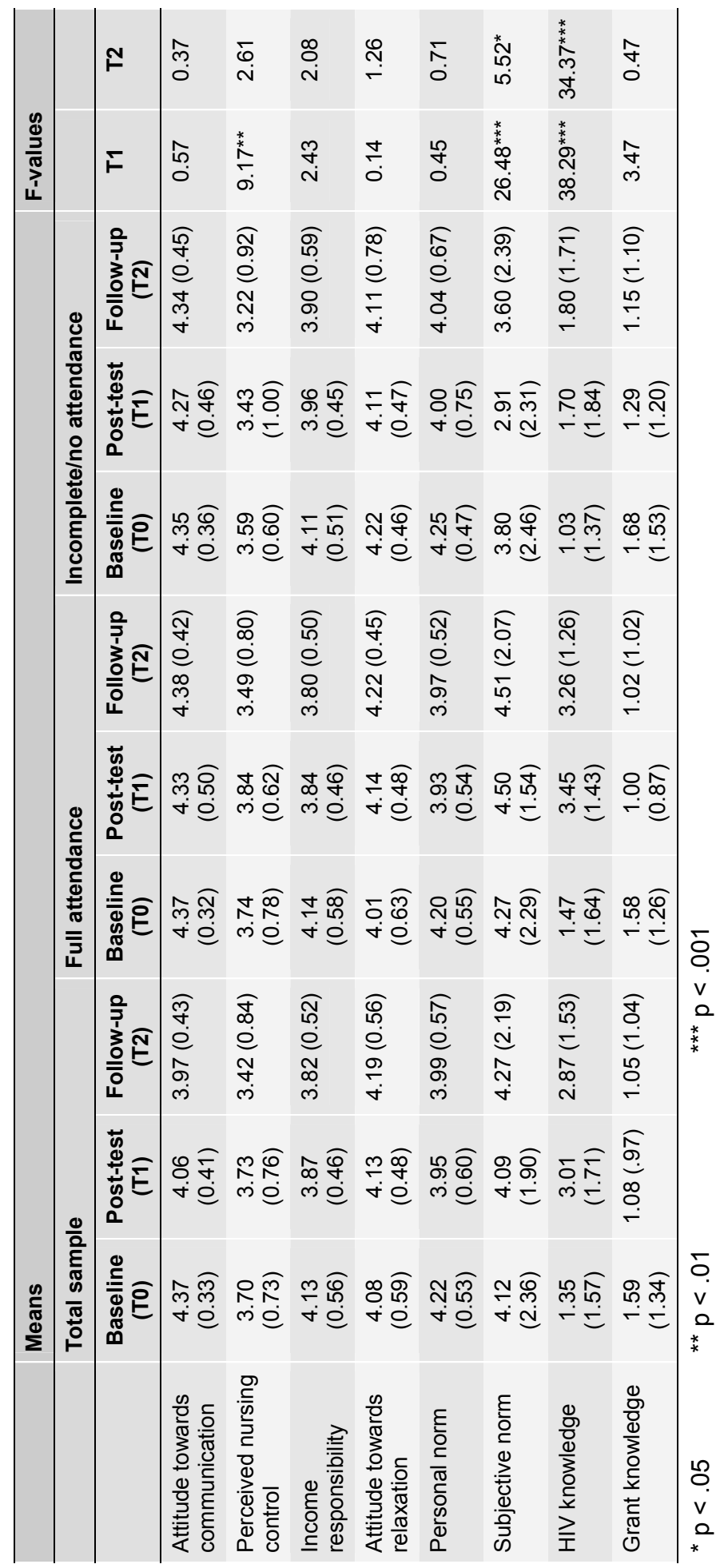




\section{Discussion}

The findings of this pilot study provide important information for the development of future intervention programs for older caregivers. Compared to baseline, the results both at post-test and follow-up show that after the intervention participants perceived themselves more able to relax, showed less depression and less feelings of helplessness, they also increased their perceived control over daily activities, improved their attitude towards people living with HIV and AIDS, and increased their HIV and AIDS knowledge. When compared to baseline, only post-test participants showed less passive coping skills and only at follow-up participants increased their proactive coping skills and their attitude towards relaxation. Unanticipated, negative effects were also found. Compared to baseline, at post-test as well as at follow-up participants showed lower feelings of responsibility towards providing income, lower ability to provide income, less knowledge on accessing grants, and a lower personal norm towards providing care. Only at post-test participants showed less proactive coping skills compared to baseline, and only at follow-up participants showed less perceived control over nursing activities.

Comparing participants who completed all workshop sessions with those that had incomplete or no participation showed that participants who completed all workshops were more able to relax themselves. They also reported a more positive attitude towards people living with HIV or AIDS and an increased knowledge about HIV and AIDS. Participants who attended all workshops were also more likely to perceive themselves able to provide care for their dependents and showed higher subjective norms towards providing care at both post-test and follow-up compared to participants who only partly or did not participate. In addition, they showed a higher perceived control over nursing care activities, but only at immediate post-test. 
Overall, the results show that the intervention had a positive effect on assisting older caregivers in their care-giving responsibilities. They were more able to handle their care-giving tasks as they felt more in control over their daily activities, had more knowledge about HIV and AIDS, showed a more positive attitude towards people with HIV and AIDS, were better able to relax themselves, improved their pro-active coping skills, and reduced their depression and feelings of helplessness. These results show that some of the important problems that older people face as caregivers can be alleviated and perhaps even be prevented by an intervention such as this.

As the results show, no changes were found for the ability to communicate with children and grandchildren and attitudes towards communication. It is likely that the information, discussions and roleplaying during the workshops were not sufficient to facilitate intergenerational communication. More research is needed to gain a deeper understanding of the social, cultural and historical relationships and communication processes between elders and children or grandchildren. The intervention also showed that a different approach is needed to create conditions that allow older people to improve their financial situation by accessing grants for their dependents or participate in income generating activities. As for their ability to provide income, their perceived responsibility to provide income and their knowledge to provide income reduced after participating in the study, it is likely that the information that was provided and the discussions during the workshops were insufficient. A possible reason could be that the information on accessing grants for dependents was too general and perhaps too much. Even though the information was kept as basic as possible, it might have been confusing to participants to talk about all available grants as some of the information might not have been applicable to them. Also no practical income generating skills were taught in the workshops in order to facilitate higher incomes. 
The findings of this study demonstrate significant positive changes amongst older people in providing care for their children and grandchildren. The results highlight the need for future intervention programs addressing communication between generations, perhaps by including younger people in workshop sessions with their parents or grandparents and explore what they can learn from each other in order to create more understanding and respect for both the older and younger generations. Besides future intervention programs should focus on strengthening the financial basis for handling care-giving activities, by improving accessibility to the grants available for dependents, as well as investigating income generating possibilities. In addition to disseminating information on social grants, older people should be provided with practical assistance to fill up forms and be accompanied to the social grant office when applying for grants for themselves or their dependents. Also older people should be assisted in learning practical skills for possible income generating activities, such as how to start a vegetable garden or sewing club and how to sell their products.

Community support structures should be investigated to see where they could be of any assistance to the caregivers. Also constructs already investigated and proven changeable, like perceived relaxation abilities, proactive coping skills and knowledge on HIV and AIDS, as well as theoretical constructs such as attitudes towards people living with HIV or AIDS should be included in future programs. Any intervention targeting older people will need to be implemented in a manner that considers the socio-economic circumstances and the history of the impoverished life that they have come through. The implementation of such interventions will be strengthened by the commitment and input from different stakeholders from social development and community organizations.

As this study was conducted among a specifically selected group of older people in the Eastern Cape in South Africa, caution should be observed in generalizing results to other populations. Also 
the results may not be representative to all older people in Motherwell as only caregivers that were known and visible to the community were recruited for participation in the study. This might have resulted in an over-representation of active older caregivers who were able to cope better with their care-giving responsibilities as they had access to community support services such as Age-in-Action. Also no causal conclusions can be drawn from this study as a convenience sample was used without randomization to different study groups. Although no significant differences of demographic variables were found between participants who fully attended the workshops and those who did not, confounding could have taken place based on the variables that determined the attendance in the workshops, as well as the results of the intervention.

In conclusion, the findings demonstrate that through the intervention the older caregivers developed specific skills that enabled them to provide better care for their sick adult children and grandchildren. Depression and feelings of helplessness were reduced helping them to cope better with their psychosocial needs. Further research and programs should focus on intergenerational communication and structural needs, such as financial assistance and income generation to assist older caregivers of sick adult children and grandchildren with their heavy tasks. 


\section{Appendix A: A detailed description of the pilot health education intervention}

The intervention package consisted of weekly training workshops for older people and consisted of four modules of about three hours each and focused on:

- providing accurate information about HIV and AIDS

- providing older people with skills to bridge the communication gap between them and their children/grandchildren

- $\quad$ providing older people with skills to provide basic home-based nursing care to their sick children

- providing older people with up-to date information on the social support services available

- creating in older people an appreciation for the need to do relaxation exercises and skills to achieve this

\section{Workshops}

The manual was translated and all workshops were conducted in isiXhosa.

Module 1 addressed mainly issues around HIV and AIDS and included topics to:

- Increase factual knowledge about HIV and AIDS, such as:

- modes of causes, transmission, spread, prevention and protection

- differences between HIV and AIDS

- the importance of getting tested

- practical true and false exercise

- Explore the behavior of young people, such as:

- understanding behavior of young people 
- how to use the information on the behavior of young people to talk to young people in a more constructive way

- Improve practical relaxation techniques and basic exercises, such as:

- the importance of relaxation

- practical relaxation exercises

Module 2 addressed intergenerational communication and focused on:

- Communication between grandparents and children/grandchildren in a socio-culturally sensitive manner by exploring communication between grandparents and grandchildren through case examples

- Improving skills of older people to communicate effectively with children and grandchildren, such as:

- what is needed for effective communication with children

- how to use positive body language

- practical exercise focusing on how to get to know your child

- how to talk about sensitive matters such as love, relationships, and sexuality

- Improving practical relaxation techniques and basic exercises, such as:

- stretching exercise

- breathing exercise

Module 3 focused on providing basic home-based nursing care for sick grandchildren and mainly sick adult children. The workshop aimed at:

- Improving practical skills for home-based nursing care, such as:

- giving a bed bath: what is needed, procedures, preparation, stripping the bed, undressing the sick person, tips for washing, how to prevent pressure sores and how to make the bed after washing

- changing the position of a sick person in bed 
- personal hygiene tips about the mouth and nails of the sick person

- nutrition for a sick person

- Improving knowledge and skills to maintain medication compliance, such as:

- why it is important to take medicine as the doctor prescribed

- practical tips on remembering to give the sick person their medication

- Improving practical relaxation techniques and basic exercises, such as:

- relaxation footbath

Module 4 explored the topic of social services and community support. The objectives of the workshop were to:

- Learn how to utilize existing social support services, by providing information on:

- different types of support

- different types of social grants and what is required to qualify for them

- accessing child grants

- where to apply for a grant

- what to do when a grant application is unsuccessful

- reasons for grants being suspended from the applicant for example failure to re-apply, change in circumstances

- explore the need and interest for an older people's support group

- Relaxation techniques and basic exercises, such as:

- stretching exercises

- examples of different activities that promote relaxation 
Chapter 6

General Discussion 


\section{General Discussion}

In the past few years, research on older people as caregivers of sick adult children and orphaned or vulnerable grandchildren has increasingly gained prominence. Existing research has focused on the wide variety of needs and challenges of older caregivers. With limited resources they have become often the main providers of care and income for their sick adult children and orphaned or vulnerable grandchildren. However, the situation of older people providing care for children and grandchildren is not new. In the past, labour migration created a reciprocal exchange within families, in which older people facilitated the economic movement of younger adults by providing care for their grandchildren and safeguarding family land and households (Chazan, 2008; Hosegood \& Timaeus, 2006; Madhavan, 2004; Marais, 2005). What is new to the situation is that HIV and AIDS undermine the traditional reciprocal care arrangements as migrant parents fall ill and die, and can no longer provide remittances to the grandparents caring for their children (Chazan, 2008; Madhavan, 2004; Marais, 2005). In order to support older people in their care-giving role and to support the development of constructive structures to assist orphaned grandchildren with improved care and a better future, it is critical to better understand the psychosocial context in which older people provide care.

This dissertation focuses on understanding the psychosocial and socio-economic context in which older people provide care as a result of HIV and AIDS for sick and orphaned children and grandchildren in the informal settlements of Motherwell and Uitenhage in the Eastern Cape of South Africa. As many informal settlements in the Eastern Cape, Motherwell and Uitenhage are faced with high unemployment rates, poverty and service delivery backlogs (Nelson Mandela Bay Municipality, 2008). Also is HIV and AIDS highly prevalent in the area, with most HIV infections among the 
African population. The African population therefore also has to cope with the largest number of both maternal and paternal orphans (Development Partners, 2007).

Furthermore this study evaluated the effectiveness of a targeted intervention programme which aimed to address psychosocial determinants of perceived ability among older people to provide care for sick and orphaned children and/or grandchildren. The first study used a qualitative approach to explore the expanding role of older people and their responsibilities and challenges as care-givers of children and grandchildren as a result of HIV and AIDS. The second and third studies were quantitative and were conducted to generate an understanding of the relevant psychosocial correlates of experienced grief and perceived ability to provide different kinds of care. The last study comprised of a systematic evaluation of a community-based health education intervention programme which targeted the specific needs of older caregivers in order to assist them in their care-giving responsibilities.

In this final chapter the most important results of the empirical studies described in this thesis are summarised and discussed. Also methodological aspect of the different studies are discussed, and implications for practice and recommendations for future research among the target population of older caregivers are presented.

\section{Summary of findings}

\section{Care-giving context and challenges}

Findings of our studies showed that older people in South Africa live in extended family situations with their own children, grandchildren and other dependents such as children or grandchildren from their siblings who have passed away. The older people in our sample fulfilled parenting and care-giving roles regardless of their health, income or accommodation limitations. They provided a wide range of physical, emotional and financial care activities for their 
dependents varying from general household chores to specific nursing care related tasks such as dressing wounds and the administration of medication. Although shouldered with dignity and pride older caregivers face contextual difficulties such as a serious lack of financial support and difficulties accessing grants for their dependents. Existing studies confirm financial difficulties and indicate that pensions are often the only source of income and are shared among large households with multiple dependents (Schatz \& Ogunmefun, 2007). Other studies confirm difficulties among the older people in obtaining grants, mostly due to the lack of relevant documents required for a successful grant application (Schatz \& Ogunmefun, 2007; Case \& Menendez, 2007). Expansion of the South African pension system and improvements in accessing grants seem to be urgently needed, especially since research and the present study has shown that pension grants among older people play a significant role in the improvement of children's health and development (Case \& Menendez, 2007; Duflo, 2003).

Emotionally older people suffer as they experience hurt and pain of looking after their children due to illnesses such as HIV and AIDS. They often endure pain of losing a child without proper bereavement as they have to be emotionally and physically strong to support their grandchildren that have been left behind. Additional stress is caused by too little income and the experienced role reversal as older people express disappointment of not going to be cared for by children one day, but have to continue their role as provider of care instead.

Furthermore, older people expressed difficulties in coping with issues of parenting and communication with grandchildren in a modern environment. The modern social environment creates a generation gap which reflects a dissonance in values that are respected by the older generation and the actual behaviours that young people engage in. The features of this generation gap are reflected in older people's expression of an inability to cope with, for example, youth's 
multiple sexual relationships or a lack of social etiquette. They fear that young people are growing up in an environment that lacks discipline, guidance and insight into planning for a better and more successful future for themselves and appeared to be repeating their parents' mistakes. Additionally older people seem to indicate that the breakdown of traditional norms and cultural practices is a major contributor to the burden of disease and care, a conclusion which was also drawn in a study by Posel, Kahn, and Walker (2007).

\section{Psychosocial correlates of grief}

The study in Chapter 3 demonstrates that older caregivers in South Africa experience a substantial amount of grief due to the illness or passing away of their child(ren) and/or grandchild(ren) due to AIDS. The extent to which stigma relating to HIV and AIDS was perceived and experienced by them was the factor that was most strongly associated with grief. This was followed by their worries about providing care to their dependents. Somewhat counterintuitive were the findings that a higher self-efficacy, more knowledge on providing care and more access to support services were associated with a higher level of grief. These results thus lend credence to grief of older persons being influenced by a wide range of psychosocial and environmental variables. To our surprise, the findings showed that some correlates were significantly associated in one site but not in the other, despite the fact that both sites were highly comparable in terms of demographic and socio-economic characteristics. Only in Motherwell, depression and perceived care responsibility were negatively associated with grief, while access to support showed a positive association with grief. In Uitenhage, depression as well as personal norm towards providing care were positively associated with grief, but not in Motherwell. No possible explanation could be found to provide an understanding of the differences in findings between the two sites, however these site-dependent differences point to the need to be careful in generalising findings to other geographical areas. 
Additional research is always needed even though the setting and population might seem highly comparable to the ones in our study sites.

Findings from existing literature confirm that stigma from society is one of the major limiting factors of providing adequate care for people living with HIV or AIDS (Mwinituo \& Mill, 2006), as stigma exacerbates the emotional state of the person who is known to have HIV or AIDS (Appleton, 2000; Posel, Kahn, \& Walker, 2007; Thomas, 2006) as well as the emotional state of the caregiver (Ntozi, 1997a; Orner, 2006). As a consequence of stigma, fear and the experience of social isolation, shame, ridicule and loneliness may further increase levels of emotional stress and worry (Iwelunmor, Airhihenbuwa, Okoror, \& Belue, 2008).

The strong association between grief and worries about providing care may well be explained by strong cultural and normative beliefs of older persons regarding their caring duties on the one hand and difficulty in coping with the complex care situation with sick dependents and low access to support for caring on the other hand. Although done out of love, providing care places considerable emotional, financial and physical demands on the caregivers and restricts them in their daily functioning. With limited resources and support older persons are not well equipped to provide care-giving to this extent (Ndaba-Mbata \& Seloilwe, 2000; Nyambedha, Wandibba, \& Aagaard-Hansen, 2003a; Ssengonzi, 2007) and emotional consequences such as stress, sadness tension and worries are inevitable.

A counterintuitive finding is that older people are more likely to experience grief as their self-efficacy to provide care increases. An explanation may be that those who were more confident in their tasks as caregiver, might feel better able to allow themselves to grieve, as they may not see it as something negative, but as a part of life that has to be worked through. Working through has been defined as "a cognitive process of confronting a loss, of going over the events 
before and at the time of the death, of focussing on memories and working towards detachment from the deceased" (Stroebe, 1992).

More knowledge on providing care seemed to increase feelings of grief, no possible explanation could be found for this. Also more availability of support was shown to increase feelings of grief. When older people have access to more social support, they have more opportunities to share their emotions, and to cope with their loss. However, sharing emotions could be rather unpleasant and induce feelings of sadness and grief, as verbalising emotions does not necessarily reduce the emotional load and does not contribute to emotional recovery (Pennebaker, Zech, \& Rimé, 2001).

\section{Psychosocial correlates of the ability to provide care}

Recent, mostly qualitative studies have identified potential factors related to care-giving by older people (Freeman \& Nkomo, 2006; Ssengonzi, 2007, 2009; Williams \& Tumwekwase, 2001). There has been a lack of evidence regarding the relative contributions of these factors in understanding the care-giving behaviour of older people. Chapter 4 of this thesis describes the most important psychosocial correlates of different dimensions of caring ability that were explored, that is the perceived ability to provide nursing care, to communicate effectively with children and grandchildren, to provide income, and to relax.

Important psychosocial constructs in explaining human behaviour such as attitudes, perceived behaviour control, personal and subjective norms, proofed to be important correlates across the four ability dimensions, next to knowledge on accessing grants. The most important correlates of caregivers' perceived ability to provide nursing care were more knowledge on accessing grants and a more positive personal norm towards providing care. Only in Uitenhage personal norm and knowledge about HIV and AIDS were positively associated with the ability to provide nursing care, whereas only in Motherwell perceived behaviour control to provide nursing care showed a positive 
association with the ability to provide nursing care. Perceived ability to communicate effectively with children and grandchildren was associated most strongly with a more positive attitude towards communication for both sites, and only in Uitenhage also with knowledge about accessing grants. A more negative attitude towards people living with HIV or AIDS and a more positive attitude towards communication were the primary correlates of perceived ability to provide income. Differences were found between sites, as feelings of helplessness and perceived income responsibility were positively associated with perceived ability to provide income only in Motherwell. In Uitenhage the attitude towards people with HIV and AIDS showed a positive impact on the ability to provide income. Knowledge on accessing grants was negatively associated with perceived ability to provide income in Motherwell, whereas in Uitenhage the association was positive. The main correlates of perceived ability to relax were a more negative attitude towards communication, lower perceived responsibility to provide income and a higher perceived behaviour control over providing nursing care. Only in Uitenhage perceived control over nursing care activities, knowledge on accessing grants and the attitude towards providing income were positively associated with perceived ability to relax.

Somewhat counterintuitive was the finding that a more negative attitude towards people living with HIV or AIDS was associated with a higher perceived ability to provide income. This finding could possibly be explained by the impact that interpersonal or environmental variables have on the ability to provide income. Factors such as for example a bad relationship between the sick person and the caregiver, whether the reason to take on the care-giving role is out of emotional affection and willingness (Nyambedha, Wandibba, \& Aagaard-Hansen, 2003a) or moral obligation, or fear of disclosure and stigma from the community (Moore, 2008; Mwinituo \& Mill, 2006) could have contributed to a more negative attitude towards people living with HIV or AIDS. However these factors might not necessarily 
restrict an older person's ability to provide income, especially when support from family or community members (Orner, 2006) is available. A negative attitude towards people living with HIV and AIDS could on the other hand also lead to social exclusion of the person infected with HIV as well as the family caregiver (Mwinituo \& Mill, 2006), resulting in less support from the community. The counterintuitive finding that a more negative attitude towards communication and a more negative attitude towards providing income contributed to higher perceived ability to relax might be explained by older people not perceiving themselves responsible to provide income and to communicate effectively with children and grandchildren and therefore allow themselves time to relax. Although the study sites were demographically comparable with slight demographic differences, differences were found in findings between the sites but based on existing studies and literature, no possible explanation could be provided for this.

\section{The evaluation of a community based intervention}

\section{programme}

Chapter 5 provides evaluates the effectiveness of a community-based intervention programme for older people as caregivers and provides important information for the development of future intervention programmes for older caregivers. The intervention consisted of four weekly interactive workshop-sessions, containing a range of topics relevant to the caregivers. The first module provided accurate information about HIV and AIDS and explored the behaviour of young people of today. Module 2 addressed skills to bridge the generational communication gap between caregivers and their children and grandchildren. Module 3 focussed on skills to provide basic home-based nursing care to sick children. Module 4 explored the topic of social assistances and provided information on accessing available support services for older people themselves and their dependent 
children. In addition, each workshop contained a component in which practical relaxation techniques and basic exercises were trained.

Overall, the results show that the intervention had a positive effect on assisting older caregivers in their care-giving responsibilities. Participants with complete attendance of the workshops were compared to those with incomplete attendance. Caregivers who attended all workshops reported a higher ability to handle their care-giving tasks as they felt more in control over their daily activities, had more knowledge about HIV and AIDS, showed a more positive attitude towards people with HIV and AIDS, were better able to relax themselves, improved their pro-active coping skills, and reduced their depression and feelings of helplessness. These results show that some of the important problems that older people face as caregivers can be alleviated and perhaps even be prevented by an intervention such as described in Chapter 5.

No changes were found for some of the outcome variables such as the ability to communicate with children and grandchildren and attitudes towards communication. It is likely that the information, discussions and role-playing during the workshops were not sufficient to facilitate intergenerational communication. More research is needed to gain a deeper understanding of the social, cultural and historical relationships and communication processes between elders and children or grandchildren. The intervention also showed that a different approach is needed to create conditions that allow older people to improve their financial situation by accessing grants for their dependents or participate in income generating activities. As for their ability to provide income, their perceived responsibility to provide income and their knowledge to provide income reduced after participating in the study. It is likely that the information that was provided and the discussions during the workshops were insufficient. A possible reason could be that the information on accessing grants for dependents was too general and perhaps too much. Even though the information was kept as basic as possible, it might have been 
confusing to participants to talk about all available grants as some of the information might not have been applicable to them. Also no practical income generating skills were taught in the workshops in order to facilitate higher incomes, thus possibly leaving participants with a perceived absence of control and creating a situation of learned helplessness (Seligman, 1975).

\section{Methodological limitations}

\section{Research design}

A convenience sample of isiXhosa speaking older people over the age of 60 years, who reported to be caring for children and/or grandchildren as a result of HIV or AIDS, participated in this study. No detailed population statistics were available from which a probability sample could be drawn as the research was conducted in a setting with limited resources. We were unable to select a random probability sample and had to settle for a convenience sample with older people that were associated with Age-in-Action, a local nongovernmental organisation and partner in the study, in order to include as many older caregivers as possible. However, through a snow-ball effect, other older people in the community and friends of Age-inAction became aware of the study and showed interest to participate. They were also approached by community health workers and were invited to participate in the study if they matched the inclusion criteria. As the community health workers, all employed by Age-inAction had thorough knowledge of the area and were acquainted with the caregivers, they were able to approach all older people that would be in a position and condition to be interviewed. As several community health workers were responsible for data collection, all participants were nested within a certain interviewer in the studies in the Chapters 3 and 4. Although every effort was made to reduce possible interviewer bias by cautiously selecting community health workers and thoroughly training them, the cross-sectional study in 
Chapter 3 did not control for possible influences of the interviewer's responses. Due to advancing insight, we controlled for possible interviewer bias in the study which followed in Chapter 4. As the studies were conducted among a specifically selected group of older people in the Eastern Cape in South Africa, caution should be observed in generalising results to populations of older caregivers in other areas of the country. Also the results may not be representative to all older people in Motherwell and Uitenhage as only caregivers that were known and visible to the community were recruited for participation in the study. This might perhaps have resulted in an overrepresentation of active older caregivers who were able to cope better with their care-giving responsibilities as they had access to community support services such as Age-in-Action.

Also no causal conclusions can be drawn from the evaluation study in Chapter 5 as a convenience sample was used without randomisation at the individual level to different study groups. Initially the study design comprised of a quasi-experimental controlled trial with a convenience sample of older caregivers in Motherwell as experimental group and a similar sample in Uitenhage as control group. In Motherwell older caregivers were to receive the intervention programme, whereas in Uitenhage caregivers were encouraged to continue their usual Age-in-Action activities. In the course of the data analysis, however, basic baseline analyses showed significant differences between the two sites. This could have been corrected for in further analyses, however also interactions between baseline measures and study site were found, indicating that the impact of the baseline measures on the post-intervention measures was different for both study conditions. Also, in Uitenhage data were collected by the same community health workers at all three time points, and therefore could have influenced the validity of the data. In Motherwell, new community members were trained for the collection of post-test and follow-up data who all were blind to the contents of the workshop sessions, increasing the validity of the data collection. Therefore it 
was decided to exclude the data collected in Uitenhage from the study. This unfortunate reality severely limited the effect analysis of the intervention programme as no control group was available.

Preliminary analyses of the data further showed that not all caregivers in Motherwell completed all four intervention modules. In order to increase the insight of the effect of the intervention, we decided to not only base the evaluation of the intervention on an analysis of baseline versus post-test differences but also include a comparison between older caregivers in Motherwell who completed the full intervention and those who did not or only partly, in what can be called a quasi-experimental design.

\section{Research instrument}

As different community workers interviewed the participants, differences between interviewers might have occurred; causing interviewer bias that could have had an impact on the outcomes of the studies. However, every effort has been made to reduce the risk of interviewer bias by carefully selecting and intensively training interviewers. Besides, in Chapter 4 we corrected for possible interviewer bias in the analysis by means of linear mixed model analysis, including the interviewer as random effect variable.

Furthermore we were aware that the changes that we made to the existing validated scales used such as the Hopkins Symptom Checklist-25 (Derogatis, Lipman, Richels, Uhlenhuth, \& Covi, 1974; Hesbacher, Rickels, Morris, Newman, \& Rosenfeld, 1980) and the Ways of Coping Checklist (Folkman \& Lazarus, 1985) might have changed the psychometric properties of these measurement scales. However, as the scales were tested in mostly Western study settings with a different sample, every effort was made to check the scale structures and psychometric properties for this specific population and context by means of factor and reliability analysis. 


\section{Recommendations for further research and interventions}

More case studies are needed to confirm our findings and extend the current knowledge base of psychosocial correlates of the ability to provide home care in the context of HIV and AIDS. Furthermore, the differences in findings between demographically comparable sites emphasise the importance of a detailed needs assessment and analysis of important predictors of outcome variables for every new study context. In addition to differences between sites, differences might also be found within sites among subpopulations, for example when comparing grandparents caring for only grandchildren versus grandparents caring for both adult and grandchildren. Differences between subpopulations should be thoroughly studied in future research.

The findings of the effect study described in Chapter 5 demonstrate significant positive changes amongst older people who participated in all workshop sessions versus those who did not, in providing care for their children and grandchildren. The results highlight the need for future intervention programmes addressing communication between generations, perhaps by including younger people in workshop sessions with their parents or grandparents and explore what they can learn from each other in order to create more understanding and respect for both the older and younger generations. Besides future intervention programmes should focus on strengthening the financial basis for handling care-giving activities, by improving accessibility to the grants available for dependents, as well

as investigating income generating possibilities. In addition to disseminating information on social grants, older people should be provided with practical assistance to fill-in forms and be accompanied to the social grant office when applying for grants for themselves or their dependents. Also older people should be assisted in learning 
practical skills for possible income generating activities, such as how to start a vegetable garden or sewing club and how to sell their products.

In addition, the findings from the study described in Chapter 3 emphasise that the focus of future intervention programmes should not only be on the individual but also on the social environment as perceived stigma related to HIV and AIDS from the community was identified as the most important correlate of grief. Understanding the beliefs of HIV and AIDS in the wide community as well as the involvement of community members in the development of a programme is essential to enhance acceptance of the intervention by the target population and the community at large as well as for successful programme implementation.

Community support structures should be investigated to see where they could be of any assistance to the caregivers. Also constructs already investigated and proven changeable, like perceived relaxation abilities, proactive coping skills and knowledge on HIV and AIDS, as well as theoretical constructs such as attitudes towards people living with HIV or AIDS should be included in future programmes. Any intervention targeting older people will need to be implemented in a manner that considers the socio-economic circumstances and the history of the impoverished life that they have come through. The implementation of such interventions will be strengthened by the commitment and input from different stakeholders from social development and community organisations.

\section{Conclusions}

Overall the study findings have provided us with an overview of the most important roles and challenges of older people caring for children or grandchildren as a result of HIV and AIDS. By determining the relative order of importance of social cognitive constructs in understanding grief and the perceived ability to provide 
care in the context of HIV and AIDS, these findings add relevant information to previous research (e.g. Schatz \& Ogunmefun, 2007; Ssengonzi, 2007, 2009; Williams \& Tumwekwase, 2001) that mostly used qualitative study designs to determine the needs, consequences and challenges of older caregivers. The study also has provided a core list of possible intervention targets (e.g. attitudes, personal norms towards providing care, perceived behaviour control over providing nursing control and knowledge on accessing grants), which provides valuable information for the systematic design and evaluation of educational interventions to assist older people in coping with their care-giving concerns. However, additional structural needs such as financial assistance, medical support, nursing care, transport support, safety, food security and access to community support are also needed and actors of different sectors in society including health, social development and community organisations should be encouraged to prioritise and address the problems that older caregivers face. 


\section{References}

Ainsworth, M. \& Dayton, J. (2003). The impact of the AIDS epidemic on the health of older persons in Northwestern Tanzania. World Development, 31, 131-148.

Ankrah, E.M. (1993). The impact of HIV/AIDS on the family and other significant relationships: the African clan revisited. AIDS Care, 5, 5-22.

Appleton, J. (2000). 'At my age I should be sitting under that tree': the impact of AIDS on Tanzanian lakeshore communities. Gender and Development, 8, 19-27.

Aranda, S. \& Milne, D. (2000). Guidelines for the complicated bereavement risk in family members of people receiving palliative care. Melbourne: Centre for Palliative Care.

Barrientos, A., Ferreira, M., Gorman, M., Heslop, A., Legido-Quigley, H., Lloyd-Sherlock, P., Møller, V., Saboia, J., \& Teixeira Werneck Vianna, M.L. (2003). Non-contributory pensions and poverty prevention: A comparative study of Brazil and South Africa. London: HelpAge International.

Berger, B.E., Ferrans, C.E., \& Lashley, F.R. (2001). Measuring stigma in people with HIV: Psychometric assessment of the HIV stigma scale. Research in Nursing and Health, 24, 518-529.

Boon, H., James, S., Ruiter, R.A.C., Van den Borne, B., Williams, E., $\&$ Reddy, P. (under review). Challenges for elderly caregivers in a time of HIV and AIDS in South Africa: A focus group study.

Boon, H., Ruiter, R.A.C., James, S., Van den Borne, B., Williams, E., \& Reddy, P. (2010a; in press). Correlates of grief among older people caring for children and grandchildren as a result of HIV and AIDS in South Africa. Journal of Aging and Health. 
Boon, H., James, S., Ruiter, R.A.C., Van den Borne, B., Williams, E., \& Reddy, P. (2010b). Explaining perceived ability among older people to provide care as a result of HIV and AIDS in South Africa. AIDS Care, iFirst, 1-10.

Brink, T.L, Yesavage, J.A., Lum, O., Heersema, P., Adey, M.B., \& Rose, T.L. (1982). Screening tests for geriatric depression. Clinical Gerontologist, 1, 37-44.

Case, A. and Menendez, A. (2007). Does money empower the elderly? Evidence from the Agincourt demographic surveillance site, South Africa. Scandinavian Journal of Public Health, 35 (S69), 157-164.

Cattell, M.G. (1990). Models of old age among the Samia of Kenya: family support of the elderly. Journal of Cross-Cultural Gerontology, 5, 375-394.

Chazan, M. (2008). Seven 'deadly' assumptions: unraveling the implications of HIV/AIDS among grandmothers in South Africa and beyond. Ageing \& Society, 28, 935-958.

Clark, S.J., Collinson, M.A., Kahn, K., Drullinger, K., \& Tollman, S.M. (2007). Returning home to die: Circular labour migration and mortality in South Africa. Scandinavian Journal of Public Health, 35 (S69), 35-44.

Collinson, M. A., Tollman, S. M., \& Kahn, K. (2007). Migration, settlement change and health in post-apartheid South Africa: Triangulating health and demographic surveillance with national census data. Scandinavian Journal of Public Health, 35 (S69), 77 84.

Connor, M., \& Norman, P. (2005). Predicting health behaviour: A social cognition approach. In: Predicting health behaviour: Research and practice with social cognition models. Connor, M. and Norman, P. (Eds.). Berkshire, UK: Open University Press. 
Cox, C. (2002). Empowering African American custodial grandparents. Social Work 47: 45-54.

Dayton, J. \& Ainsworth, M. (2002). The elderly and AIDS: Coping strategies and health consequences in rural Tanzania. Policy research division working papers No. 160. Washington, DC: Population Council.

Dayton, J. \& Ainsworth, M. (2004). The elderly and AIDS: Coping with the impact of adult death in Tanzania. Social Science \& Medicine, 59, 2161-2172.

Department of Health, South Africa (2007). National HIV and Syphillis Antenatal Sero-Prevalence Survey in South Africa 2006. Directorate Health Systems Research, Research Coordination \& Epidemiology.

Department of Provincial and Local Government South Africa (2005). Motherwell Urban Renewal Programme. Available online at: www.thedplg.gov/za/urp/Reports/Cabinet\%20Lekgotla/Motherwel lv2.pdf [03.11.2008].

Department of Provincial and Local Government, South Africa (2008). Economic snapshot: Motherwell, Eastern Cape. Available online at: http://www.thedplg.gov.za/urp/index2.php?option=com docman\& task $=$ doc view $\&$ gid $=87 \&$ Itemid $=54[03.11 .2008]$

Department of Social Development, South Africa (2003). Fact sheet: Social grants beneficiaries. Available online at http://www.welfare.gov.za/Documents/2003/Budget\%20Vote/Fact \%20Sheets/benf.pdf [03.11.2008].

Department of Social Development, South Africa (2008). Media Statement: Minister invites all to celebrate Grandparents Day http://www.dsd.gov.za/index.php?option=com content\&task=vie $\underline{\text { w\&id }=67 \& \text { Itemid }=106}$ [accessed on 25 February 2009] 
Derogatis, L.R., Lipman, R.S., Richels, E.H., Uhlenhuth, E.H, \& Covi, L. (1974). The Hopkins Symptom Checklist (HSCL). A selfreport system inventory. Behavioral Science, 19, 1-15.

Development Partners (2007). Nelson Mandela Bay Municipality Demographic Update and Socio-Economic Analysis / Quality of Life in 26 'Change Areas' 2006/7. Available online at: http://www.dpart.co.za/documents/DemographicUpdateExecSum mary.pfd [03.11.2008]

Duflo, E. (2003). Grandmothers and granddaughters: Old-age pensions and intrahousehold allocation in South Africa. The World Bank Economic Review, 17, 1-25.

Eastern Cape Provincial Government (2008). The Nelson Mandela Metropolitan District. Available online at http://www.ecprov.gov.za/page.php?index $=12$ [15.07.2008]

Eastern Cape Department of Social Development (2008). Socioeconomic \& demographic profile: Nelson Mandela Metropole. Available online at http://www.socdev.ecprov.gov.za/statistics/demographics/nelsonmandela area info.htm [29.09.2008].

Ferreira, M. (2004). HIV/AIDS and family well-being in Southern Africa: towards an analysis of policies and responsiveness. A brief synthesis paper prepared for a United Nations Department of Economic and Social Affairs Division for Social Policy and Development Policy workshop in Windhoek, Namibia.

Folkman, S. \& Lazarus, R.S. (1985). If it changes it must be a process: Study of emotion and coping during three stages of a college examination. Journal of Personality and Social Psychology, 48, 150-170.

Folkman, S., Lazarus, R.S., Dunkel-Schetter, C., DeLongis, A., \& Gruen, R. (1986). The dynamics of a stressful encounter: 
Cognitive appraisal, coping and encounter outcomes. Journal of Personality and Social Psychology, 50, 992-1003.

Foster, G. (1998). Today's children - challenges to child health promotion in countries with severe AIDS epidemics. AIDS Care, 10 (S1), S17-S23.

Foster, G., Makufa, C., Drew, R., Kambeu, S., \& Saurombe, K. (1996). Supporting children in need through a community-based orphan visiting programme. AIDS Care, 8, 389-404.

Foster, G., Makufa, C., Drew, R., Mashumba, S., \& Kambeu, S. (1997). Perceptions of children and community members concerning the circumstances of orphans in Zimbabwe. AIDS Care, 9, 391-405.

Freeman, M. \& Nkomo, N. (2006). Guardianship of orphans and vulnerable children. A survey of current and prospective South African caregivers. AIDS Care, 18, 302-310.

HelpAge International (2003). Policy report: Forgotten families Older people as carers of orphans and vulnerable children. Brighton: International HIV/AIDS Alliance.

HelpAge International (2004). The cost of love. Older people in the fight against AIDS in Tanzania. Dar es Salaam: HelpAge International Tanzania.

Hesbacher, P.T., Rickels, K., Morris, R.J., Newman, H., \& Rosenfeld, H. (1980). Psychiatric illness in family practice. Journal of Clinical Psychiatry, 41, 6-10.

Hosegood, V. \& Timeaus, I.M. (2006). HIV/AIDS and older people in South Africa. In: Aging in Sub-Saharan Africa. Recommendations for furthering research. B. Cohen \& J. Menken (Eds.). Washington, D.C.: The National Academies Press. 
Iwelunmor, J., Airhihenbuwa, C.O., Okoror, T.A., \& Belue, R. (2008). Family systems and HIV/AIDS in South Africa. International Quarterly of Community Health Education, 27, 321-335.

Juma, M., Okeyo, T., \& Kidenda, G. (2004). "Our hearts are willing, but...". Challenges of elderly caregivers in rural Kenya". Horizons Research Update. Nairobi: Population Council.

Kipp, W., Tindyebwa, D., Karamagi, E., \& Rubaale, T. (2007a). How much should we expect? Family caregiving of AIDS patients in rural Uganda. Journal of Transcultural Nursing, 18, 358-365.

Kipp, W., Tindyebwa, D., Rubaale, T., Karamagi, E., \& Bajenja, E. (2007b). Family caregivers in rural Uganda: The hidden reality. Health Care for Women International, 28, 856-871.

Knodel, J. (2005). Researching the impact of the AIDS epidemic on older-age parents in Africa: Lessons from studies in Thailand. Generations Review, 15, 16-22.

Knodel, J. \& VanLandingham, M. (2002). The impact of the AIDS epidemic on older persons. AIDS, 16 (S3), S77-S83.

Knodel, J., Watkins, S., \& VanLandingham, M. (2003). AIDS and older persons: An international perspective. Journal of Acquired Immune Deficiency Syndromes, 33, S153-S165.

Krueger, R.A. (1998). Moderating focus groups. Focus group kit 4. Thousand Oaks (CA): Sage Publications Inc.

Lindsey, E., Hirschfeld, M., Tlou, S., \& Ncube, E. (2003). Homebased care in Botswana: Experiences of older women and young girls. Health Care for Women International, 24, 486-501.

Madhavan, S. (2004). Fosterage patterns in the age of AIDS: continuity and change. Social Science \& Medicine, 58, 1443-1454. 
Madhavan, S. \& Schatz, E. (2007). Coping with change: Household structure and composition in rural South Africa, 1992 - 2003. Scandinavian Journal of Public Health, 35(S69), 85-93.

Marais, H. (2005). Buckling: The impact of AIDS in South Africa. Pretoria: University of Pretoria Press.

May, J. (2003). Chronic poverty and older people in South Africa. CPRC Working Paper 25. South Africa: Chronic Poverty Research Centre.

Middleton, W., Raphael, B., Burnett, P., \& Martinek, N. (1998). A longitudinal study comparing bereavement phenomena in recently bereaved spouses, adult children and parents. Australian and New Zealand Journal of Psychiatry, 32, 235-241.

Moore, A.R. (2008). Older poor parents who lost an adult child to AIDS in Togo, West Africa: A qualitative study. OMEGA, 56, 289-304.

Mwinituo, P. \& Mill, J.E. (2006). Stigma associated with Ghanaian caregivers of AIDS patients. Western Journal of Nursing Research, 28, 369-382.

Ndaba-Mbata, R.D. \& Seloilwe, E.S. (2000). Home-based care of the terminally ill in Botswana: knowledge and perceptions. International Nursing Review, 47, 218-223.

Nelson Mandela Bay Municipality (2008). Integrated Development Plan 2008 - 2012 of the Nelson Mandela Bay Metropolitan Municipality. Available online at http://www.nelsonmandelabay.gov.za/Documents.aspx?objID=85 $\underline{\mathrm{cmd}}=$ download\&docID $=487$ [03.11.2008]

Ntozi, J.P.M. (1997a). AIDS morbidity and the role of the family in patient care in Uganda. Health Transition Review, 7(S), 1-22. 
Ntozi, J.P.M. (1997b). AIDS mortality in Uganda circumstances, factors and impact of death. Health Transition Review, 7(S), 207224.

Ntozi, J.P.M. \& Nakayiwa, S. (1999). AIDS in Uganda: how has the household coped with the epidemic? The continuing African HIV/AIDS epidemic. Canberra: Health Transition Centre, National Centre for Epidemiology and Population Health, Australian National University.

Nurses Association of Botswana (2004). Caring for the caregivers. Cape Town: Policy Project.

Nyambedha, E.O., Wandibba, S., \& Aagaard-Hansen, J. (2003a). "Retirement lost" - the new role of the elderly as caretakers for orphans in western Kenya. Journal of Cross-Cultural Gerontology, 18, 33-52.

Nyambedha, E.O., Wandibba, S. and Aagaard-Hansen, J. (2003b). Changing patterns of orphan care due to the HIV epidemic in Western Kenya. Social Science and Medicine, 57, 301-311.

Ogunmefun, C. \& Schatz, E. (2006). Working paper - Caregivers' sacrifices: The opportunity costs of adult morbidity and mortality on female pensioners in rural South Africa. Boulder, Colorado: Population Program, Institute of Behavioral Science, University of Colorado.

Olenja, J.M. (1999). Assessing community attitude towards homebased care for people with AIDS (PWAS) in Kenya. Journal of Community Health, 24, 187-199.

Opiyo, P., Yamano, T., \& Jayne T.S. (2008). HIV/AIDS and homebased health care. International Journal for Equity in Health, 7, 14.

Orner, P. (2006). Psychosocial impacts on caregivers of people living with AIDS. AIDS Care, 18, 236-240. 
Pennebaker, J.W., Zech, E., \& Rimé, B. (2001). Disclosing and sharing emotion: Psychological, social and health consequences. In: Handbook of bereavement research. Consequences, coping and care. Stroebe, M.S., Hansson, R.O., Stroebe, W. and Schut, H. (Eds.). Washington: American Psychological Association.

Posel, D., Kahn, K., \& Walker, L. (2007). Living with death in a time of AIDS: A rural South African case study. Scandinavian Journal of Public Health, 35 (S69), 138-146.

Reddy, P. (2005). "Inkala ixinge etyeni: Trapped in a difficult situation". The burden of care on the elderly in the Eastern Cape, South Africa. Horizons Research Update. Johannesburg: Population Council.

Saleh-Onoya, D., Braxton, N.D., Sifunda, S., Reddy, P., Ruiter, R., Van den Borne, B., Walters, T.P., Lang, D., \& Wingood, G.M. (2008). SISTA South Africa: The adaptation of an efficacious HIV prevention trial conducted with African-American women for isiXhosa-speaking South African women. Journal of Social Aspects of HIV/AIDS, 5, 186-191.

Save the Children UK (2003). Care for children infected and those affected by HIVIAIDS. A handbook for community health workers. Kampala, Uganda: Save the Children UK.

Schatz, E.J. (2007). "Taking care of my own blood": Older women's relationships to their households in rural South Africa. Scandinavian Journal of Public Health, 35 (S69), 147-154.

Schatz, E. \& Ogunmefun, C. (2007). Caring and contributing: The role of older women in rural South African multi-generational households in the HIV/AIDS era. World Development, 35, 13901403.

Seeley, J., Wolff, B., Kabunga, E., Tumwekwase, G., \& Grosskurth, H. (2009). 'This is where we buried our sons': People of advanced 
old age coping with the impact of the AIDS epidemic in a resource-poor setting in rural Uganda. Ageing \& Society, 29, 115134.

Seligman, M.E.P. (1975). Helplessness: On depression, development, and death. San Francisco: W.H. Freeman.

Sifunda, S. (2006). Ubudoda Abukhulelwa - Responsible Manhood. Cape Town: Medical Research Council.

Ssengonzi, R. (2007). The plight of older persons as caregivers to people infected/affected by HIV/AIDS: Evidence from Uganda. Journal of Cross-Cultural Gerontology, 22, 339-353.

Ssengonzi, R. (2009). The impact of HIV/AIDS on the living arrangements and well-being of elderly caregivers in rural Uganda. AIDS Care, 21, 309-314.

Statistics South Africa (2000). Measuring Poverty in South Africa. Pretoria: Statistics South Africa.

Statistics South Africa (2007). Community survey 2007. Municipal data on household services. Pretoria: Statistics South Africa.

Statistics South Africa (2008). Mid-year population estimates 2008. Pretoria: Statistics South Africa.

Steinberg, M., Johnson, S., Schierhout, G., \& Ndegwa, D. (2002). Hitting home. How households cope with the impact of the HIV/AIDS epidemic. A survey of households affected by HIV/AIDS in South Africa. Washington, DC: Henry J. Kaiser Family Foundation.

Stroebe, M.S. (1992). Coping with bereavement: A review of the grief work hypothesis. Omega, 26, 19-42.

Stroebe, M. S., Hansson, R.O., Stroebe, W., \& Schut, H. (2001). Introduction: Concepts and issues in contemporary research on bereavement. In: Handbook of bereavement research. 
Consequences, coping and care. Stroebe, M.S., Hansson, R.O., Stroebe, W., \& Schut, H. (Eds.). Washington: American Psychological Association.

Stroebe, M., Schut, H., \& Stroebe, W. (2007). Health outcomes of bereavement. The Lancet, 370, 1960-1973.

Theut, S.K., Jordan, L., Ross, L.A., \& Deutsch, S.I. (1991). Caregiver's anticipatory grief in dementia: A pilot study. International Journal of Aging and Human Development, 33, 113118.

Thomas, F. (2006) Stigma, fatigue and social breakdown: Exploring the impacts of HIV/AIDS on patient and carer well-being in Caprivi Region, Namibia. Social Science \& Medicine, 63, 31743187.

UNICEF (2003). Africa's orphaned generations. New York: UNICEF.

Vlok, M.E. (1977). Manual of basic nursing care. Johannesburg: Juta \& Company, Ltd.

Williams, A. \& Tumwekwase, G. (2001). Multiple impacts of the HIV/AIDS epidemic on the aged in rural Uganda. Journal of Cross-Cultural Gerontology, 16, 221-236.

Willis, N., McGilvray, M., McNally, L. \& Pawinski, R (2005). Paediatric palliative care manual for home base carers. Available online at: http://www.aidsmap.com/en/docs/77989B86-BA724ABF-B70C-7A7F2543AD2B.asp [07.06.2006].

Wittenberg, M. \& Collinson, M.A. (2007). Household transitions in rural South Africa, 1996-2003. Scandinavian Journal of Public Health, 35 (S69), 130-137. 
World Health Organization (2002). The impact of AIDS on older people in Africa: Zimbabwe case study. Geneva: World Health Organization.

Yesavage, J.A., Brink, T.L., Rose, T.L., Lum, O., Huang, V., Adey, M., \& Von Leirer, O. (1983). Development and validation of a geriatric depression screening scale: A preliminary report. Journal of Psychiatric Research, 17, 37-49. 


\section{Summary}

The increasing HIV and AIDS epidemic in South Africa poses a substantial burden on older people, who in the past few decades have become the backbone of community care for sick adult children and their grandchildren who have become orphaned and rendered vulnerable by the death or illness of their parents. Even though existing research has focussed on various aspects of the HIV and AIDS epidemic, very little detailed analysis has been directed at understanding the effects of the epidemic on older people. The impact of HIV and AIDS on older caregivers and their ability to cope with the burden and responsibilities of care imposed upon them has not been adequately studied and has certainly not been the subject of systematic intervention studies designed to mitigate the effects of HIV and AIDS on the lives of older caregivers as well as those for whom they care. The main purpose of the research described in this thesis was to explore the scope of care provided by older people, to see which psychosocial determinants were most important in explaining feelings of grief as a result of providing care, to determine the most important correlates of the perceived ability to provide care, as well as the development and evaluation of a community based intervention programme targeted at supporting older people in their tasks as caregivers. This research was carried-out in Motherwell and Uitenhage in the Eastern Cape province of South Africa.

Chapter 1 gives an overview of the context and extent to which older people provide care for their sick adult children and/or grandchildren. It provides information on the history of older people providing care for grandchildren as children would leave the household due to labour migration, and elaborates on the changes in care responsibilities as HIV and AIDS are currently undermining the traditional reciprocal care arrangements. It further offers background information on the financial, emotional, physical and social challenges 
that older people cope with as a result of providing care. The chapter concludes with expressing the need for intervention programmes targeting the specific needs of older caregivers, such as providing home-based nursing care, communicating effectively with children and grandchildren and accessing grants for dependents.

Chapter 2 emanates from a qualitative study among 89 older caregivers. This study explored the expanding changing role of older people as caregivers and their responsibilities and challenges in caring for sick adult children and orphaned grandchildren. The study investigated the scope of care provided by older persons for HIV and AIDS affected dependants and analyse the challenges and needs of the carers. The findings show that older caregivers find themselves in a situation of having to meet the care-giving, parenting and productive needs of their families. They reported receiving very little or no support, which seriously compromises their coping abilities. The caregiving responsibilities challenge the carer's financial, emotional, social and physical conditions. Also difficulties in communication with children of younger generations were expressed, due to a generation gap. This study has highlighted the changing role of older people as providers of care for their sick and vulnerable children and grandchildren. Instead of being the ones to be cared for at their old age, older people continue their heavy task as main provider of care for their family. Additionally the findings highlight the need for further research to understand the extent to which older people are affected by the care they provide, in order to inform the development of supporting structures and interventions.

Chapter 3 describes psychosocial and environmental determinants associated with grief and was conducted among 820 older caregivers, of which 488 from Motherwell and 332 from Uitenhage. The study focussed on the experience of grief among older adults caring for children and grandchildren as a result of HIV and AIDS and identified predictors of grief as variables for change to develop coping strategies and support. The results showed that older 
caregivers experience substantial amounts of grief due to the illness or passing of their children or grandchildren due to AIDS. The extent to which stigma relating to HIV and AIDS was perceived and experienced by the caregivers was the factor that was most strongly associated with grief. This finding confirms that stigma from society is one of the limiting factors in providing adequate care for people living with HIV or AIDS and has negative consequences on the emotional state of the caregiver as well as the care-recipient. This implies that in order to reduce feelings of grief, stigma should be addressed and a wider population should be included in future intervention programmes.

Chapter 4 was based on a cross-sectional study among older caregivers and explored the determinants of the perceived ability to care for children and grandchildren in the domains of providing nursing care, communicating with children and grandchildren, generating income, and to relax. Results showed that perceived ability among older people to provide nursing care was primarily dependent on the level of knowledge on accessing support grants and personal norm towards providing care. Perceived ability to communicate effectively with children and grandchildren was most strongly predicted by a positive attitude towards communication and perceived ability to provide income was influenced by a more negative attitude towards people living with HIV or AIDS. Perceived ability to relax was dependent on more negative attitudes towards communication, lower perceived responsibility to provide income, and a higher perceived behaviour control over providing nursing care. The findings of this study add relevant information to understanding the psychosocial context in which older people provide HIV and AIDS related care and support the development of targeted programmes to assist older people in their role as caregiver.

Chapter 5 presents the effectiveness of a pilot intervention programme that was implemented among 202 older caregivers in Motherwell and aimed to address the determinants of perceived ability 
among older people to provide care for sick children and vulnerable grandchildren, by using suitable strategies such as for example verbal persuasion and practical skills development. The objectives of the intervention programme were to (1) build capacity among older caregivers to provide quality care to sick and orphaned children and grandchildren, (2) enhance the ability of older caregivers to cope with their psychosocial needs, (3) facilitate intergenerational communication between older caregivers and their dependents, including on HIV and AIDS prevention issues, and (4) facilitate the dissemination of information to older people on existing community and social support services. It was hypothesised that participation in the four sessions of the developed health education intervention would result in more knowledge on topics associated with HIV and AIDS and a higher perceived ability to take care of sick adult children and grandchildren compared to those who did not or not fully participate in the workshops. The results demonstrated that older people who participated in all four workshops perceived themselves more able and in control to provide nursing care and better able to relax. They also showed a more positive attitude towards people living with HIV or AIDS and reported an increased level of HIV and AIDS knowledge. The results provided valuable information and addressed the psychosocial and environmental needs of caregivers upon which the development of future interventions may be based. In addition, the results also show that collaboration with relevant stakeholders from society would be urgently advised to address also the structural needs of the caregivers such as financial assistance and access to community support.

Chapter 6 provides a general discussion and interpretation of the results, followed by the description of methodological limitations of the different studies and implications for practice. The chapter concludes with recommendations to inform further research on the implications of HIV and AIDS for older people and suggestions for 
the development of community-based interventions addressing the needs of older caregivers in the South African context. 


\section{Samenvatting}

De HIV en AIDS epidemie in Zuid-Afrika vormt een steeds grotere belasting voor oudere mensen. In de afgelopen twee decennia zijn ouderen belangrijke verleners van zorg geworden voor volwassen kinderen die ziek zijn door HIV of AIDS, en voor kleinkinderen die achtergebleven zijn na de dood of ziekte van één of beide ouders. Hoewel onderzoek is gedaan naar verschillende aspecten van de HIV en AIDS epidemie is er tot op heden weinig onderzoek gedaan naar de gevolgen van de epidemie voor oudere mensen. Het effect van HIV en AIDS op oudere zorgverleners en hun mogelijkheden om aan de zorglast en -verantwoordelijkheden het hoofd te bieden, is onvoldoende bestudeerd. Ook zijn er nog geen systematisch ontwikkelde interventies ontwikkeld om de zorglast die ouderen ervaren als gevolg van HIV en AIDS, te verlichten. Dit proefschrift heeft tot doel (1) inzicht verkrijgen in de psychosociale en sociaalecomonische factoren die van invloed zijn op de ervaren zorglast van ouderen en de gevoelens van verdriet na het overlijden van dierbaren en (2) een interventieprogramma ontwikkelen en evalueren gericht op het ondersteunen van oudere mensen bij hun taken als zorgverleners. Het onderzoek werd uitgevoerd in Motherwell en Uitenhage in de provincie Eastern Cape in Zuid-Afrika in een samenwerkingsverband tussen de Medical Research Council of South Africa en het Horizons Program van de Population Council.

Hoofdstuk 1 geeft een overzicht van de financiële en sociale context waarin ouderen zorg verlenen aan kinderen en kleinkinderen die zijn getroffen door HIV en AIDS. In het verleden hebben grootouders in Zuid Afrika altijd al zorg gedragen voor kleinkinderen terwijl hun kinderen als gevolg van arbeidsmigratie het gezin verlieten op zoek naar werkgelegenheid. Nieuw aan de hedendaagse situatie is dat HIV en AIDS de traditionele wederkerige regeling van zorg ondermijnen. Vanwege ziekte of overlijden kunnen volwassen 
kinderen geen of minder inkomen verstrekken, met als gevolg dat ouderen nu de volle verantwoordelijkheid en zorg hebben voor kleinkinderen. In dit hoofdstuk worden de financiële, emotionele en sociale problemen besproken die oudere mensen als gevolg van het verstrekken van zorg het hoofd moeten bieden. Het hoofdstuk besluit met de conclusie dat interventieprogramma's gericht op de specifieke behoeften van oudere zorgverleners, hard nodig zijn en dat het daarom van groot belang is dat de belangrijkste behoeften van de zorgverleners in kaart worden gebracht. Zo is er een gebrek aan kennis en vaardigheden met betrekking tot het verlenen van eenvoudige thuiszorg aan zieke volwassen kinderen en een tekort aan kennis van het voorkomen van HIV en AIDS.

Hoofdstuk 2 beschrijft een kwalitatieve studie onder 89 oudere zorgverleners. Deze studie onderzocht de veranderende rol van oudere mensen als verleners van zorg en hun verantwoordelijkheden, problemen en behoeften bij het zorgen voor zieke volwassen kinderen en kleinkinderen als gevolg van HIV en AIDS. De bevindingen tonen aan dat oudere zorgverstrekkers zich in een situatie bevinden waarin zij moeten voorzien in de inkomsten en in de zorgbehoefte en opvoedkundige behoefte van hun families, waarbij ze zeer weinig of geen steun ontvangen. Deze rol vergt het uiterste van hun zorgcapaciteit en heeft financiële, emotionele, sociale en fysieke consequenties. Verder zorgt de generatiekloof tussen jong en oud voor de nodige moeilijkheden in hun communicatie. De bevindingen benadrukken de behoefte aan verder onderzoek om de consequenties van het verlenen van zorg door ouderen beter te begrijpen, en ondersteunende voorzieningen en interventies te ontwikkelen.

Hoofdstuk 3 beschrijft de psychosociale en omgevingsdeterminanten die gerelateerd zijn aan gevoelens van verdriet als gevolg van het verlies van een kind door HIV en AIDS. Het onderzoek is uitgevoerd onder 820 oudere zorgverleners, waarvan er 488 uit Motherwell en 332 uit Uitenhage afkomstig waren. De studie concentreerde zich op het ervaren van verdriet bij oudere 
zorgverleners en identificeerde de belangrijkste voorspellers van verdriet. De resultaten tonen aan dat oudere zorgverleners veel verdriet ervaren als gevolg van ziekte of overlijden van hun kinderen of kleinkinderen als gevolg van HIV of AIDS. De mate waarin stigmatisering met betrekking tot HIV en AIDS wordt waargenomen en ook als zodanig wordt ervaren door zorgverleners, was de factor die het sterkst met verdriet werd geassocieerd. Ook was de mate waarin ouderen zich zorgen maken over de taken die zij als zorgverlener moeten uitvoeren, sterk geassocieerd met verdriet. Deze bevindingen bevestigen dat stigmatisering vanuit de maatschappij en de mate waarin ouderen zich zorgen maken, beperkende factoren zijn in het verstrekken van adequate zorg voor mensen die met HIV of AIDS leven en tevens voor negatieve emotionele gevolgen zorgen voor zowel de zorgverlener als zorgontvanger. Dit onderzoek impliceert dat om het ervaren gevoel van verdriet te verminderen, toekomstige interventies zich onder andere zouden moeten richten op het verminderen van stigma vanuit de samenleving.

Hoofdstuk 4 is gebaseerd op een cross-sectionele studie onder oudere zorgverleners. De studie onderzoekt de determinanten van de mate waarin ouderen zich in staat achten om aan hun kinderen en kleinkinderen eenvoudige thuiszorg te bieden, te communiceren met kinderen en kleinkinderen, en voor inkomsten en ontspanning voor zichzelf te zorgen. De resultaten tonen aan dat de waargenomen capaciteit onder oudere mensen om eenvoudige thuiszorg te verlenen grotendeels afhankelijk was van het niveau van kennis over het verkrijgen van financiële steuntoelagen en hun persoonlijke norm ten aanzien van het verstrekken van zorg. De waargenomen capaciteit om effectief met kinderen en kleinkinderen te communiceren werd het sterkst voorspeld door een positievere attitude ten opzichte van communicatie. Een negatievere attitude ten opzichte van mensen die met HIV of AIDS leven was de belangrijkste voorspeller van de waargenomen capaciteit om voor een inkomen te zorgen. De waargenomen capaciteit om te ontspannen was afhankelijk van een 
negatievere attitude ten opzichte van communicatie, lagere waargenomen verantwoordelijkheid om inkomen te verwerven, en een hogere waargenomen gedragscontrole over het verstrekken van thuiszorg. De bevindingen van deze studie voegen relevante informatie toe aan het begrijpen van de psychosociale context waarin oudere mensen zorg verlenen. Tevens kunnen de resultaten de ontwikkeling van gerichte programma's om oudere mensen bij te staan in hun rol als zorgverlener, ondersteunen.

Hoofdstuk 5 beschrijft een studie naar de doeltreffendheid van een pilot interventieprogramma dat onder 202 oudere zorgverleners in Motherwell werd uitgevoerd. De interventie had tot doel verandering aan te brengen in belangrijke psychosociale determinanten van de zorgcapaciteit van ouderen, zodat zij zichzelf beter in staat achtten om zorg te verlenen. De doelstellingen van het interventieprogramma waren (1) het verhogen van de capaciteit van oudere zorgverleners om kwaliteitszorg aan zieke kinderen en kleinkinderen te verstrekken, (2) het verbeteren van de capaciteit van oudere zorgverleners om aan hun psychosociale behoeften het hoofd te bieden, (3) het vergemakkelijken van communicatie tussen oudere zorgverleners en hun kinderen en kleinkinderen en (4) het vergemakkelijken van de verspreiding van informatie over beschikbare sociale voorzieningen aan oudere mensen. Strategieën die hiervoor gebruikt werden, waren onder andere mondelinge overtuiging en de praktische training van vaardigheden. De resultaten tonen aan dat oudere mensen die aan alle vier de workshops deelnamen, zichzelf bekwamer vonden om zorg te verlenen en een hogere controle ervaarden om eenvoudige thuiszorg te verstrekken. Ook waren zij beter in staat zich te ontspannen, toonden een positievere houding ten opzichte van mensen die met HIV of AIDS leven en hadden zij een hoger kennisniveau van HIV en AIDS. Bovendien toonden de resultaten aan dat samenwerking met relevante stakeholders uit de maatschappij noodzakelijk is om structurele behoeften van oudere zorgverleners, zoals financiële hulp en toegang tot sociale zekerheid, te verbeteren. 
In hoofdstuk 6 worden de resultaten van het uitgevoerde onderzoek besproken, gevolgd door een beschrijving van voorstellen voor toekomstig onderzoek en voor de ontwikkeling van interventieprogramma's gericht op oudere zorgverleners in de ZuidAfrikaanse context. 


\section{Acknowledgements}

Thank you to all the people who have supported me throughout the process of completing this research and dissertation.

My gratitude goes to my promotors and co-promotor Professor Bart van den Borne, Professor Priscilla Reddy and Dr Rob Ruiter for your valuable guidance, support and enthusiasm throughout the study. To the co-authors thank you for your important input. Many thanks to the National Health Promotion Research and Development Unit and to the Department of Work and Social Psychology for giving me the opportunity to do this PhD. Thank you to the colleagues at the National Health Promotion Research and Development Unit and at the Department of Work and Social Psychology for the support and for making me feel at home. Thanks to the staff at Age-in-Action, the community health workers, the older people of Motherwell and Uitenhage in the Eastern Cape of South Africa for your cooperation in the project.

Many thanks to my family and friends for your inspiration and support. Special thanks to my parents for your encouragement, to John for your unfailing love, care and belief in my ability during the whole

process and to Ralph for being such a good baby and allowing me to complete this work. 


\section{Curriculum Vitae}

Hermien Boon was born on the $2^{\text {nd }}$ of March 1979 in Alkmaar, The Netherlands. At age 18 she travelled to Zambia for a year of voluntary work, after which she completed her secondary school at the Regionaal Opleidingen Center in Nijmegen. In 1999 she started her Health Sciences study at Maastricht University and specialised in Health Education and Promotion. In 2004 she completed her Master's degree. From March 2005 until June 2007 she worked as a scientist at the Medical Research Council (MRC) at the Health Promotion Research and Development Unit. At the MRC she started her PhD, which she finalised at the Department of Work and Social Psychology at Maastricht University. 
